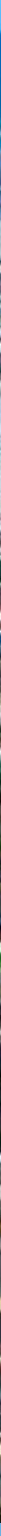

\title{
Effecten van het EU-Mercosur-akkoord op de Nederlandse economie
}





\section{Effecten van het EU-Mercosur-akkoord op de Nederlandse economie}

Caitlyn Carrico, ${ }^{1}$ Siemen van Berkum,${ }^{1}$ Andrzej Tabeau, ${ }^{1}$ Jakob Jager, ${ }^{1}$ Nora Plaisier ${ }^{2}$

1 Wageningen Economic Research

2 Ecorys Rotterdam

Dit onderzoek is uitgevoerd door Wageningen Economic Research en Ecorys in opdracht van de Rijksoverheid. Het onderzoek is gefinancierd door het ministerie van Buitenlandse Zaken.

Wageningen Economic Research

Wageningen, oktober 2020

RAPPORT 2020-065

ISBN 978-94-6395-531-7 
Carrico, C., S. van Berkum, A. Tabeau, J. Jager, N. Plaisier, 2020. Effecten van het EU-Mercosurakkoord op de Nederlandse economie. Wageningen, Wageningen Economic Research, Rapport 2020-065. 60 blz.; 23 fig.; 11 tab.; 27 ref.

Dit onderzoek beoordeelt de economische effecten van het EU-Mercosur-akkoord op Nederland. Op macro-economisch niveau wordt de potentiële winst van de bbp-groei geschat op 0,03\%, wat neerkomt op 287 miljoen euro, uitgaande van een volledige uitvoering van het akkoord in 2035. Op sectorniveau verslechtert de Nederlandse bilaterale handelsbalans met Mercosur voor landbouwproducten (behalve zuivel), maar een substantiële groei van de handelsbalans in de verwerkende industrie en de dienstensector resulteert in een algehele positieve netto handelswinst voor Nederland. Op bedrijfsniveau zijn de geschatte inkomenseffecten positief voor varkens- en pluimveebedrijven, vrijwel nul voor melkvee- en akkerbouwbedrijven en negatief voor rund- en kalfsvleesbedrijven.

This study assesses the economic effects of the EU-Mercosur Agreement for the Netherlands. At the macroeconomic level, potential gains in GDP growth are estimated to be $0.03 \%$, amounting to $287 \mathrm{~m}$ euros, assuming a full implementation of the Agreement by 2035. At the sectoral level, the Dutch bilateral trade balance with Mercosur contracts for agricultural products (except for dairy), but substantial growth of the trade balance in the manufacturing and service sectors results in an overall positive net trade gain for the Netherlands. At the farm level, estimated income effects are positive for pig and poultry farms, close to zero for dairy and arable farms, and negative for beef and veal farms.

Trefwoorden: handel, agrifood, Nederland, EU, Mercosur, Brazilië, Argentinië, Uruguay, Paraguay

Dit rapport is gratis te downloaden op https://doi.org/10.18174/530438 of op www.wur.nl/economicresearch (onder Wageningen Economic Research publicaties).

(C) 2020 Wageningen Economic Research

Postbus 29703, 2502 LS Den Haag, T 07033583 30, E communications.ssg@wur.nl, www. wur.nl/economic-research. Wageningen Economic Research is onderdeel van Wageningen University \& Research.

\section{(cc) BY-NC}

Dit werk valt onder een Creative Commons Naamsvermelding-Niet Commercieel 4.0 Internationaallicentie.

(C) Wageningen Economic Research, onderdeel van Stichting Wageningen Research, 2020 De gebruiker mag het werk kopiëren, verspreiden en doorgeven en afgeleide werken maken. Materiaal van derden waarvan in het werk gebruik is gemaakt en waarop intellectuele eigendomsrechten berusten, mogen niet zonder voorafgaande toestemming van derden gebruikt worden. De gebruiker dient bij het werk de door de maker of de licentiegever aangegeven naam te vermelden, maar niet zodanig dat de indruk gewekt wordt dat zij daarmee instemmen met het werk van de gebruiker of het gebruik van het werk. De gebruiker mag het werk niet voor commerciële doeleinden gebruiken.

Wageningen Economic Research aanvaardt geen aansprakelijkheid voor eventuele schade voortvloeiend uit het gebruik van de resultaten van dit onderzoek of de toepassing van de adviezen.

Wageningen Economic Research is ISO 9001:2015 gecertificeerd.

Wageningen Economic Research Rapport 2020-065 | Projectcode 2282500386

Foto omslag: Shutterstock 


\section{Inhoud}

$\begin{array}{ll}\text { Samenvatting } & 5\end{array}$

Nederlandse handelsbetrekkingen met Mercosur onder de huidige handelsvoorwaarden en de verwachtingen met betrekking tot de effecten van het akkoord op de bilaterale handel met Mercosur

2.1 Nederlandse handelsbetrekkingen met Mercosur-landen

2.1.1 Belang van handel in goederen en diensten met Mercosur

2.1.2 Nederlandse bilaterale handelsbetrekkingen: belangrijkste geïmporteerde producten

2.1.3 Wederexport van de import uit Mercosur-landen 13

2.1.4 Nederlandse export naar Mercosur-landen $\quad 14$

2.2 Huidige handelsvoorwaarden in de bilaterale handel tussen de EU en Mercosur 15

2.2.1 Tariefstructuren $\quad 15$

2.2.2 Tariefcontingenten voor de import $\quad 16$

2.3 Verwachtingen van mogelijke effecten van wijzigingen in de handelsvoorwaarden als gevolg van het principeakkoord $\quad 17$

2.3.1 Toekomstige tariefcontingenten 18

2.3.2 Voornaamste niet-tarifaire maatregelen die van invloed zijn op de bilaterale handel tussen de EU en Mercosur en de verwachtingen van de stakeholders over de wijze waarop het akkoord de handelsbarrières als gevolg van niet-tarifaire maatregelen zou kunnenverminderen

3.1 Beschrijving van de veronderstelde scenario's, de gebruikte gegevens en de toegepaste verlagingen van de NTM-handelskosten

3.2 Macro-economische resultaten $\quad 26$

$\begin{array}{lll}3.3 & \text { Sectorspecifieke resultaten } & 31\end{array}$

$\begin{array}{lll}3.4 & \text { Conclusies uit de modellering } & 40\end{array}$

Effecten van het handelsakkoord op de inkomsten van Nederlandse agrarische gezinsbedrijven

$\begin{array}{lll}4.1 & \text { Inleiding } & 41\end{array}$

4.2 Koppeling van prijsveranderingen aan soorten landbouwbedrijven $\quad 42$

4.3 Effect van prijs- en volumeveranderingen op bedrijfsinkomsten per bedrijfstype 43

Bijlage 2 Schatting van de handelskosten door niet-tarifaire maatregelen: literatuuronderzoek naar gegevensbronnen, econometrische schattingen en implementatie in CGEmodelsimulaties

Bijlage 3 Gebruikte begrippen bij de berekening van de effecten op bedrijfsniveau in hoofdstuk 4 



\section{Samenvatting}

Dit onderzoek is uitgevoerd naar aanleiding van de motie van Voordewind c.s., die is aangenomen door de Tweede Kamer op 4 juli 2019 en waarin de overheid werd gevraagd om een kwantitatieve analyse van de effecten van het EU-Mercosur-akkoord op de Nederlandse economie. Het onderzoek gaat in op de effecten van het akkoord op de Nederlandse handelsstromen, het nationale inkomen en productie voor de landbouw-, industriële en dienstensectoren. De analyse toont de gevolgen voor de volgende specifieke sectoren: pluimveevlees, zuivel, rundvlees, varkensvlees, diervoeder, suiker, ethanol, chemicaliën, geneesmiddelen, machines, en handels- en transportdienstverlening. De analyses op bedrijfsniveau worden uitgevoerd voor Nederlandse gezinsbedrijven in de vlees- en zuivelsectoren.

Na twintig jaar onderhandelen werd op 28 juni 2019 het EU-Mercosur-akkoord gesloten (hierna akkoord genoemd). De EU en Mercosur kwamen overeen om importtarieven van respectievelijk $95 \%$ en $91 \%$ van alle tarieflijnen te verminderen over een periode van 15 jaar vanaf het moment van ratificatie. Daarnaast worden nieuwe importtariefcontingenten (importvolumes die tegen een gereduceerd of nultarief worden geïmporteerd) geïmplementeerd, waarvan sommige voortborduren op bestaande contingenten. Er zijn verder bepalingen in het akkoord opgenomen om markttoegang te faciliteren, waaronder afspraken over (het naleven van) sanitaire en fytosanitaire normen en technische handelsbarrières. Het beginselakkoord (het openbare document van de Europese Commissie waarin het akkoord wordt beschreven, van 1 juli 2019) geeft aan dat het akkoord belangrijke nieuwe mogelijkheden biedt voor bedrijven om diensten en producten aan te bieden aan beide kanten van de Atlantische Oceaan, maar op het moment van schrijven van dit rapport ontbreekt het aan gedetailleerde afspraken om dat te kunnen bevestigen.

De huidige Nederlandse handelsrelaties met Mercosur zijn beperkt: de Nederlandse export naar Mercosur bedraagt slechts 2,3\% van de totale export naar landen buiten de EU in 2018. Dit is vergelijkbaar met de EU als geheel, waarvan de export naar Mercosur maar 2,2\% van de export naar niet-EU-landen bedraagt. Ook de import vanuit Mercosur is in verhouding laag, met 2,7\% en 2,0\% van de import uit niet-EU-landen voor respectievelijk Nederland en de EU.

Met de huidige tariefstructuur betalen Nederland en andere exporteurs in de EU veel hogere tarieven om tot de Mercosur-markt toe te treden dan dat Mercosur betaalt om tot de EU-markt toe te treden. De gemiddelde tarieven voor Mercosur-goederen die in de EU worden geïmporteerd zijn bijvoorbeeld maar 3\%. Daarentegen liggen de gemiddelde tarieven voor EU-goederen die in Mercosur worden geïmporteerd tussen 7\% (Paraguay) en 14,4\% (Argentinië). Gegeven de verschillen in relatieve tarieven van exporteurs in Nederland, de EU en Mercosur kunnen exporteurs in Nederland en de EU dus relatief meer rendement verwachten door de nieuwe tariefliberalisering onder het akkoord.

De EU past tariefcontingenten toe op de invoer van rundvlees, pluimveevlees, suiker en knoflook uit Mercosur. Hoewel er momenteel verschillende tariefcontingenten van kracht zijn op rundvlees uit alle Mercosur-landen, gelden de contingenten voor de import van pluimveevlees en suiker alleen voor Brazilië en de contingenten op knoflook alleen voor import uit Argentinië. Onder het akkoord worden deze contingenten vervangen met nieuwe tariefcontingenten voor de hele Mercosur voor rundvlees, pluimveevlees, varkensvlees, ethanol, rijst, honing, maïs, kaas, melkpoeder en babymelkpoeder. Alleen voor Brazilië en Paraguay worden nieuwe contingenten op suiker geïntroduceerd. Mercosur introduceert tariefcontingenten op kaas, melkpoeder en babymelkpoeder uit de EU. De contingenten die onder het akkoord worden geïmplementeerd zijn vaak hoger dan de huidige hoeveelheden en daarom is de verwachting ook dat de handel toe zal nemen.

Naast importtarievenzijn er ook andere belangrijke handelsbelemmeringen tussen Nederland (en de EU) en Mercosur, die voortkomen uit niet-tarifaire maatregelen. In de EU-Databank Markttoegang (MADB) zijn een aantal problemen genoemd op het gebied van fytosanitaire normen en technische 
standaarden voor EU-exporteurs naar de Mercosur-markt, waaronder onvoldoende bescherming van intellectuele eigendomsrechten en geografische indicaties, en extreem lange procedures om bijvoorbeeld fytosanitaire controles (risicoanalyse op plantenziekten) uit te voeren of om exportvergunningen goed te keuren. Hoewel de afspraken in het akkoord bedoeld zijn ter verbetering van veel van deze problemen, doet het aantal problemen vermoeden dat het verbeteringsproces erg veel tijd en middelen zal kosten.

Om inzicht te krijgen in de verwachtingen rondom het akkoord zijn er gesprekken gevoerd met vertegenwoordigers van het Nederlandse bedrijfsleven in de landbouw-, industrie- en dienstensectoren. Zij gaven aan dat de handel op den duur naar verwachting zal toenemen door de verlaagde tarieven. Ook betwijfelen ze of het akkoord er voor zal zorgen dat de regelgeving omtrent fytosanitaire normen en technische standaarden beter op elkaar worden afgestemd en worden geïmplementeerd zodat de handel wordt aangemoedigd. De huidige openbaar beschikbare tekst van het akkoord beschrijft vooral het samenwerkingsproces om overeenkomstige standaarden te bereiken, maar niet welke doelen wanneer moeten worden behaald. Daarom is het volgens de geïnterviewden uit het bedrijfsleven erg onzeker of dit handelsakkoord de belemmeringen die voortkomen uit verschillen van huidige niet-tarifaire maatregelen zal verhelpen,.

De effecten van het akkoord zijn kwantitatief doorgerekend met het MAGNET-model, een mondiaal economisch model met internationale handelsnetwerken. Dit model is gebruikt om inzicht te krijgen in de effecten op macro-economisch en sectorniveau vanuit een hypothetische volledige implementatie van het akkoord in 2035. Op basis van de tariefveranderingen op gedetailleerd productniveau (8-cijferige tarieflijnen) zijn veranderingen in samengestelde tarieven en exportheffingen voor geaggregeerde goederen bepaald. Verder zijn de nieuwe tariefcontingenten geïmplementeerd. Tenslotte zijn de aangedragen versoepelingen van handelsbarrières door niet-tarifaire maatregelen gemodelleerd met schattingen van handelskosten veroorzaakt door niet-tarifaire maatregelen voor goederen, gedaan door de Wereldbank, en voor diensten, gedaan door de Wereldbank en de OESO.

De modelresultaten tonen zeer bescheiden geschatte macro-economische effecten van het akkoord voor Nederland, met een verwachte bbp-stijging van 0,03\% oftewel 287 miljoen euro in 2035, uitgaande van een volledig geïmplementeerd akkoord in dat jaar en in vergelijking met een basisscenario in 2035 zonder akkoord. Naar schatting stijgt het bbp van de rest van de EU-27 met 0,02\% oftewel 2,9 miljard euro. Deze lage percentages komen vooral door de economische structuur van Nederland en de EU, waarbij diensten, met meer dan tweederde van de totale economisch output, de grootste sector is. Dat betekent dus dat de landbouw- en industriesectoren, die het meest beïnvloed worden door de liberalisering (via veranderingen in tarieven en tariefcontingenten) in het kader van het akkoord in feite kleine onderdelen van de Nederlandse en Europese economie zijn.

Op sectorniveau zijn er positieve en negatieve effecten voor de Nederlandse economie, grotendeels samenhangend met het relatieve belang van import, respectievelijk export als aandeel van de productie van de sectoren. In Nederland wordt de grootste productietoename verwacht voor de sectoren overige transportmiddelen (geen motorvoertuigen) $(1,42 \%)$, geneesmiddelen $(1,16 \%)$ en pluimveevlees $(0,93 \%)$. De groei van de productie in de pluimveesector wordt veroorzaakt door indirecte effecten van het akkoord. De productie in de pluimveesector in de rest van de EU zal naar verwachting krimpen door de concurrentie uit Mercosur, maar er is genoeg toename van de vraag in de EU waardoor de concurrerende sector in Nederland meer kan afzetten in de rest van de EU-27. De groei van de sectoren voor overige transportmachines en geneesmiddelen wordt veroorzaakt door directe effecten van het akkoord. Deze sectoren exporteren relatief veel naar Mercosur en dus stimuleert de groeiende export productie-uitbreiding. Veranderingen in de (reële) loonsom (de arbeidscomponent van de toegevoegde waarde) in sectoren volgen op productie-effecten.

Importbelemmeringen voor landbouwproducten in Nederland zijn, in vergelijking met die voor de industriële of dienstensectoren, het grootst. Daarom zullen deze sectoren na implementatie van het akkoord relatief met meer concurrentie uit Mercosur te maken krijgen. Vooral de vleesveesector en de groente- en fruitsector zullen meer importeren, met een daling van de productie tot gevolg met respectievelijk $0,61 \%$ en $0,21 \%$. De productie in de gehele rundveesector (melk en vlees) krimpt met 0,49\%. 
Voor de varkensvleessector worden weinig gevolgen verwacht. Er is weliswaar een (klein) tariefcontingent aan Mercosur toegekend, maar vanwege de huidige verschillen in veterinaire standaarden (bijv. EU-verbod op de diervoedertoevoeging ractopamine en dieridentificatie-eisen) wordt niet verwacht dat deze zal worden benut. Zo zal ook de verwachte stijging van de rundvleesimport uit Mercosur naar Europa afhangen van naleving van SPS-normen in overeenstemming met EU-regelgeving. Ook in de afgelopen jaren is de Braziliaanse export van pluimveevlees niet altijd in overeenstemming geweest met de EU-voedselveiligheidsstandaarden. Daarom is de verwachte toename van de export van pluimveevlees van Mercosur naar de EU erg afhankelijk van verdere investeringen in productiemethoden en voedselveiligheidsinspectiesystemen in Mercosur om te voldoen aan EU-regelgeving.

Over het algemeen zijn de netto resultaten voor Nederland positief, zoals te zien in de veranderingen voor de handelsbalans per sector voor bilaterale handel tussen Nederland en Mercosur in figuur S.1. Uit de bilaterale handelsbalans van landbouwproducten blijkt dat voor deze producten (uitgezonderd zuivel) de import meer groeit dan de export. De netto afname is echter relatief klein in vergelijking met de substantiële groei van de handelsbalans in de industriële sectoren en dus is de totale groei van de handelsbalans voor alle sectoren positief.

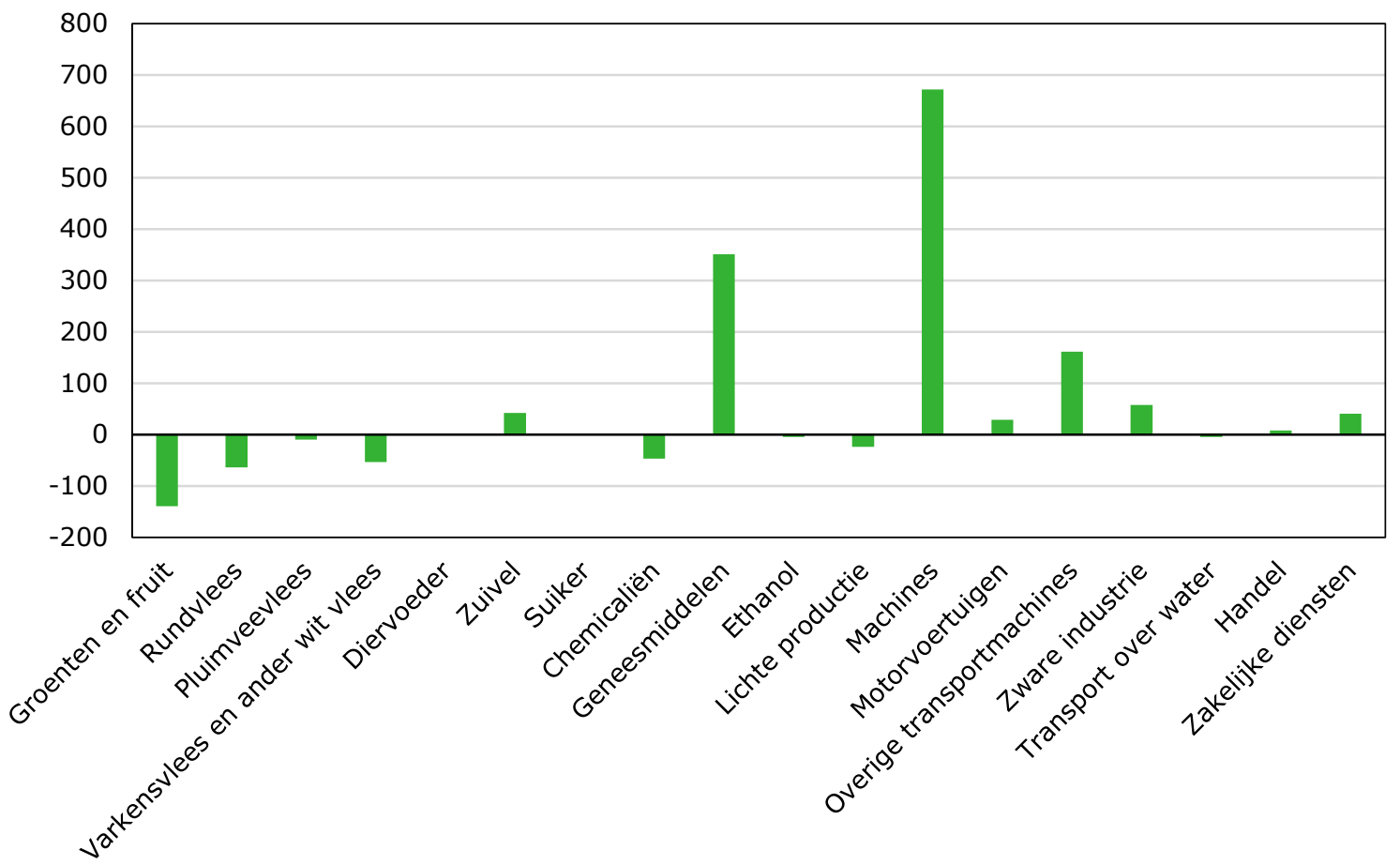

Figuur S.1 Veranderingen in de handelsbalans in 2035 tussen Nederland en Mercosur onder het Mercosur-akkoord, miljoen $€$

Op basis van de met het MAGNET-model verkregen prijs- en volumeveranderingen voor landbouwproducten zijn de inkomsteneffecten op bedrijfsniveau ingeschat. De gevolgen zijn positief voor varkensbedrijven (gemiddeld 2.100 euro per bedrijf) en pluimveebedrijven (gemiddeld 700 euro voor vleeskuikenbedrijven en 1.200 euro voor legkippenbedrijven. De inkomsteneffecten voor melkveebedrijven en akkerbouwbedrijven zijn nagenoeg nul. Pluimvee- en varkensbedrijven halen voordeel uit lagere diervoederprijzen. De inkomsteneffecten voor vleesvee- en vleeskalverenbedrijven zijn negatief. Het gemiddelde inkomsteneffect van 800 euro voor vleeskalverenbedrijven komt overeen met een afname van 2\% t.o.v. het gemiddelde inkomstenniveau in 2017-2019. Er zal vooral een negatief effect zijn op de inkomsten van de grotere bedrijven waar ook volwassen vleesrunderen worden gehouden. Voor vleesveebedrijven - een relatief kleinschalig bedrijfstype in Nederland met negatieve langetermijninkomsten - wordt het negatieve effect geschat op een afname van 700 euro van het gemiddelde inkomen per bedrijf, oftewel 5,4\%. Als kanttekening bij deze uitkomsten op bedrijfsniveau moet worden genoemd dat er geen rekening is gehouden met structurele veranderingen in de sector in 
verloop van tijd. Daarom zijn veranderingen in opbrengsten wel meegenomen, maar veranderingen in de schaalgrootte en kosten (m.u.v. voerkosten die het directe gevolg zijn van het afsluiten van het akkoord) zijn niet meegenomen in de simulaties op bedrijfsniveau. 


\section{$1 \quad$ Inleiding}

Op 28 juni 2019 hebben de EU en de vier oprichtende lidstaten van Mercosur - Argentinië, Brazilië, Paraguay en Uruguay - een 'beginselakkoord' bereikt over een vrijhandelsovereenkomst (FTA) als onderdeel van een ruimer associatieakkoord (AA). In navolging van dit akkoord heeft de Tweede Kamer op 4 juli 2019 de motie Voordewind c.s. aangenomen, waarin de regering wordt verzocht 'de voor- en nadelen van de handel met de Mercosur-landen onder dit handelsverdrag voor de Europese land- en tuinbouw en in het bijzonder voor de Nederlandse (gezins)bedrijven in de vlees- en zuivelsector, kwantificeerbaar in kaart te brengen' (2018-2019, 34 952, nr. 75; zie de volledige tekst van de motie in bijlage 1 ). Om aan de motie te voldoen heeft het Ministerie van Buitenlandse Zaken (BuZa), in samenwerking met de ministeries van Landbouw, Natuur en Voedselkwaliteit (LNV) en het Ministerie van Economische Zaken en Klimaat (EZK) opdracht gegeven aan Wageningen Economic Research en Ecorys om de effecten van het handelsakkoord tussen de EU en Mercosur op de agrarische sector te onderzoeken. In het onderzoek moet, naast naar de specifiek in de motie genoemde sectoren, ook worden gekeken naar de mogelijke gevolgen van het voorlopige onderhandelingsresultaat voor de Nederlandse economie, zowel op macro-economisch niveau als voor de Nederlandse industrie en de dienstensector.

Vandaar dat het doel van dit onderzoek is om inzicht te geven in de verwachte effecten van het handelsakkoord tussen de EU en Mercosur op de gehele Nederlandse economie, en in het bijzonder op de Nederlandse land- en tuinbouwsector, waarbij de grootste aandacht uitgaat naar de Nederlandse vlees- en zuivelsector. Ook zullen de gevolgen voor de landbouwsector binnen de EU worden geschetst. Hieruit komen de volgende deelvragen voort die in dit onderzoek worden behandeld:

- Wat is het verwachte effect van het akkoord op de handelsstromen van Nederland naar de Mercosur-landen en vice versa?

- Wat is het verwachte effect van het akkoord op de Nederlandse nationale inkomens-, productie- en arbeidscomponent van de toegevoegde waarde in het algemeen en in de drie hoofdsectoren van landbouw, industrie en diensten?

- Wat zijn de verwachte effecten van het handelsakkoord tussen de EU en Mercosur op de landbouwhandelsstromen van de EU met Mercosur en wat zijn de economische gevolgen voor de (belangrijkste) landbouwsectoren (in termen van export en import, productie, de arbeidscomponent van toegevoegde waarde, en prijzen)?

- Wat is het verwachte effect op de inkomsten en de productie in de specifieke Nederlandse agrarische deelsectoren van pluimveevlees en eieren, zuivel, rundvlees, varkensvlees, diervoeder, suiker en ethanol, en chemicaliën, geneesmiddelen, machines (inclusief apparatuur) en handels- en transportdienstverlening?

- Wat zijn de verwachte effecten op de inkomsten van Nederlandse gezinsbedrijven in de vlees- en zuivelsector?

Het onderzoek is voornamelijk kwantitatief van aard, uitgaande van een volledige implementatie van het akkoord in 2035 (rekening houdend met een implementatieperiode van 15 jaar). De kwantitatieve analyse van de macro-economische en specifieke deelsectoreffecten voor Nederland is gebaseerd op MAGNET, een internationaal wetenschappelijk onderbouwd model van de wereldeconomie.

Sectorresultaten in de landbouw worden vertaald naar effecten op de inkomsten van gezinsbedrijven door een analyse op bedrijfsniveau met behulp van de gegevens op bedrijfsniveau over de economische prestaties die worden verzameld en verwerkt in het Bedrijfsinformatienet van Wageningen Economic Research. De kwantitatieve analyse wordt aangevuld met literatuur om de context van het handelsakkoord en belangrijke aannames die van invloed zijn op de kwantitatieve uitkomsten uit te leggen. De bijdragen van deskundigen, onder anderen vertegenwoordigers van het bedrijfsleven, worden gebruikt voor potentiële niet-kwantificeerbare aspecten, met name van niettarifaire maatregelen en andere niet-gemelde handelsbeperkingen die moeten worden geïdentificeerd. 
Hoewel dit onderzoek vooral gericht is op de gevolgen voor Nederland, omvat het ook geschatte effecten van het handelsakkoord tussen de EU en Mercosur voor de (rest van de) EU. Er zijn verschillende andere onderzoeken over de verwachte effecten voor de hele EU van het handelsakkoord tussen de EU en Mercosur, onder andere een LSE-onderzoek in opdracht van de Europese Commissie ter ondersteuning van de onderhandelingen over het associatieakkoord tussen de EU en Mercosur (LSE, 2020). De vergelijking van dit onderzoek met dat van de LSE is ontoereikend omdat het laatste, naast enkele methodische verschillen, twee mogelijke scenario's van een akkoord uitwerkt, terwijl dit onderzoek de uitkomst van de onderhandelingen analyseert. Dit onderzoek is ook alleen toegespitst op de economische effecten en niet op de sociale en/of milieugevolgen, zoals het LSE-onderzoek.

Het rapport is als volgt opgebouwd. Hoofdstuk 2 beschrijft de huidige Nederlandse handelsbetrekkingen en -voorwaarden en bespreekt de mogelijke effecten van de nieuw overeengekomen tariefcontingenten en wat vertegenwoordigers van het bedrijfsleven verwachten van de openbaar beschikbare akkoordteksten die verwijzen naar kwesties van niet-tarifaire handelsbarrières. Hoofdstuk 3 presenteert de economische macro- en sectorresultaten van het handelsakkoord en hoofdstuk 4 meldt hoe prijswijzigingen als gevolg van het handelsakkoord zich zullen vertalen in effecten op de inkomsten voor verschillende bedrijfstypes in Nederland. De belangrijkste bevindingen worden samengevat in hoofdstuk 5 . 


\section{$2 \quad$ Nederlandse handelsbetrekkingen met Mercosur onder de huidige handelsvoorwaarden en de verwachtingen met betrekking tot de effecten van het akkoord op de bilaterale handel met Mercosur}

\subsection{Nederlandse handelsbetrekkingen met Mercosur- landen}

\subsubsection{Belang van handel in goederen en diensten met Mercosur}

Nederland is een handelsland, met de internationale handel als belangrijke bron van inkomsten (CBS, 2019). ${ }^{1}$ De belangrijkste markten voor Nederlands bevinden zich in de EU, met $75 \%$ van de Nederlandse export naar andere EU-landen (zie tabel 2.1 hieronder). Wat de Nederlandse import betreft (inclusief de doorvoer van de import uit niet-EU-landen naar andere EU-landen), is 55\% afkomstig uit niet-EUlanden. Dit in tegenstelling tot de andere EU-27-landen, die slechts 34\% uit niet-EU-landen importeren. Dit toont het belang van Nederland als 'toegangspoort' tot de EU en duidt er ook op dat de toegang tot de import van buiten de EU voor de Nederlandse economie van groot belang is.

De handel met Mercosur-landen is relatief bescheiden, zoals blijkt uit het aandeel van de bilaterale handel met de vier Latijns-Amerikaanse landen in de totale Nederlandse export en import in tabel 2.1 (respectievelijk $2,3 \%$ en $2,7 \%$ ). Het relatieve belang van de handel met Mercosur is verhoudingsgewijs vergelijkbaar voor Nederland en de EU-27. De bilaterale handel met Mercosur heeft een bijzonder kenmerk: De EU-27 en Nederland voeren voornamelijk industriegoederen uit naar Mercosur, terwijl de import in nagenoeg gelijke mate bestaat uit landbouw- en industrieproducten.

Tabel 2.1 Belang van de bilaterale handel in landbouw- en industriegoederen met Mercosur in de Nederlandse en Europese handelsbetrekkingen (miljarden euro's, tenzij anders vermeld), 2018

\begin{tabular}{lrr} 
& Nederland & EU-27 a) \\
Totale export & 611 & 4.846 \\
\hline Niet-EU-export & 156 & 1.790 \\
\hline Export naar M & 3,6 & 40 \\
\hline Aandeel van export naar M in niet-EU export (\%) & 2,3 & 2,2 \\
\hline & & 5 \\
\hline Export van landbouwproducten naar M & 0,5 & 35 \\
\hline Export van industrieproducten naar M & 3,1 & 2,2 \\
\hline Aandeel van export naar Mercosur in niet-EU-export (\%) & 2,3 & 4.869 \\
\hline & & 1.654 \\
\hline Totale import & 542 & 34 \\
\hline Niet-EU-import & 293 & 2,0 \\
\hline Import uit M & 8,1 & 2,7 \\
\hline Aandeel van import uit M in niet-EU-import (\%) & & 16,4 \\
\hline Import van landbouwproducten uit M & 4,2 & 17,7 \\
\hline Import van industriële producten uit M & 3,9 & \\
\hline
\end{tabular}

Bron: Eurostat COMEXT. Opm. Bij landbouwproducten gaat het om HS01-24, 29, 40-45 en 50-52.

a) EU-27 is EU-28 minus Nederland.

${ }^{1}$ Zie https://longreads.cbs.nl/nederland-handelsland-2019/nederlandse-verdiensten-aan-internationale-handel/ 
De dienstensector in Nederland is goed voor $80 \%$ van het bruto nationaal inkomen en $81 \%$ van de werkgelegenheid (CBS). Ook de export van diensten (zoals diensten op het gebied van transport, reizen, financiële zaken en telecommunicatie) is een belangrijke bron van inkomsten. Tabel 2.2 laat Nederlandse en EU-gegevens zien over handel in diensten en het belang van de Mercosur-landen als exportmarkt en als bron van de import van diensten. Uit gegevens blijkt dat de Nederlandse export naar de vier Mercosur-landen in 2018 bijna 11\% van de totale export naar niet-EU-landen vertegenwoordigde, waardoor de regio (met name Brazilië) een belangrijke markt voor de export van diensten vormt. Transportdiensten (zoals opslag en diensten verleend door expediteurs en verladers), vergoedingen voor het gebruik van intellectuele-eigendomsrechten (zoals octrooien en auteursrechten), en technische, handelsgerelateerde en andere zakelijke diensten (o.a. afvalverwerkings- en saneringsdiensten) zijn de drie belangrijkste exportcategorieën. Deze laatste categorie is veruit de belangrijkste categorie diensten die Nederland uit de Mercosur-landen (grotendeels Brazilië) importeert.

Tabel 2.2 Belang van de bilaterale handel in diensten met Mercosur in de Nederlandse en Europese handelsbetrekkingen (miljarden euro's, tenzij anders vermeld), 2018

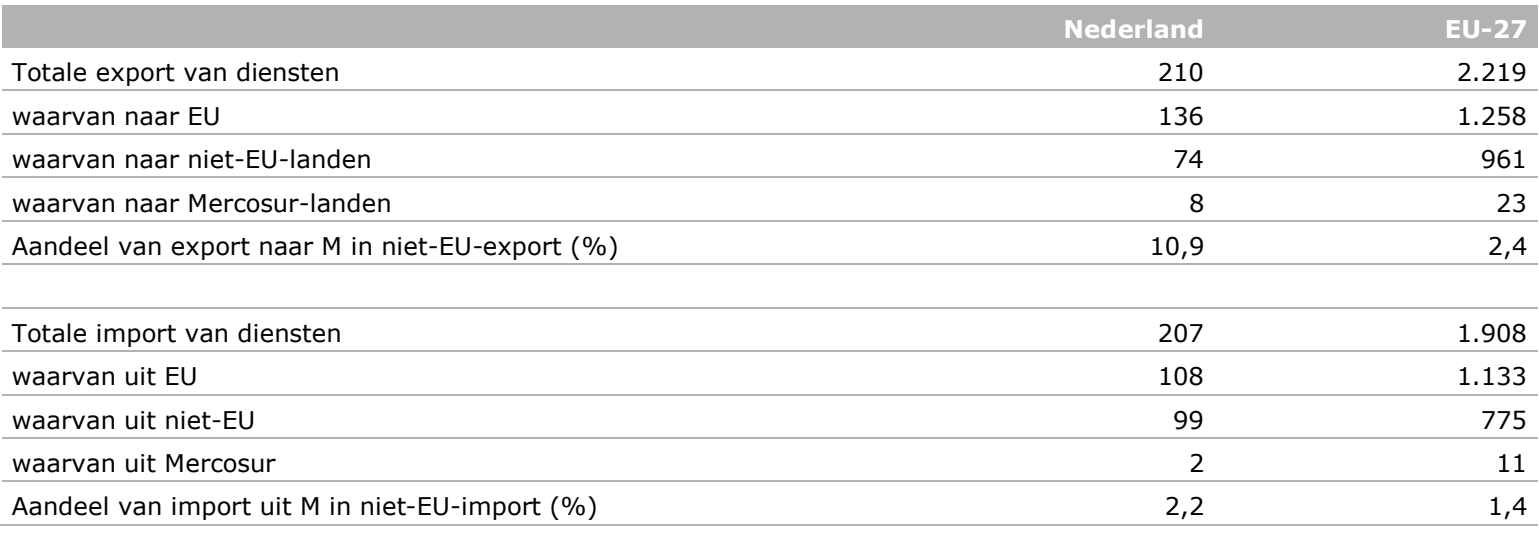

Bron: Eurostat Internationale handel in diensten (sinds 2010) (BPM6),

http://appsso.eurostat.ec.europa.eu/nui/show.do?wai=true\&dataset=bop_its6_det

\subsubsection{Nederlandse bilaterale handelsbetrekkingen: belangrijkste geïmporteerde producten}

Figuur 2.1 hieronder toont de belangrijkste productcategorieën die uit de vier Mercosur-landen worden ingevoerd. De belangrijkste landbouwproductcategorieën zijn vlees, fruit, sojabonen, bereide groenten $\&$ fruit en resten en afval van de voedingsindustrie (sojaperskoeken). Wat de import van vlees betreft, gaat het met name om kwaliteitsrundvlees ('Hilton beef') uit Argentinië en Uruguay, en pluimveevlees uit Brazilië. Fruit bestaat voornamelijk uit citrusvruchten en meloenen, en is met name afkomstig uit Brazilië. Sojabonen komen grotendeels uit Brazilië, en de import van bereide groenten en fruit bestaat voornamelijk uit vruchtensappen uit Brazilië. De import van resten en afval van de voedselindustrie bestaat grotendeels uit perskoeken, afkomstig van de winning van sojaolie, en is voornamelijk afkomstig uit Brazilië en Argentinië. De import van deze laatste categorie bedraagt bijna $70 \%$ van de totale Nederlandse import van deze productcategorie uit niet-EU-landen (zie de rechteras van onderstaande figuur). In de industriële productcategorieën bestaan de belangrijkste importstromen uit ertsen, houtpulp en ijzer. Deze categorieën betreffen grondstoffen voor verdere verwerking in de staal- en hout- en papierverwerkende industrieën. Een belangrijk aandeel van deze import lijkt te bestaan uit doorvoer naar Duitsland en andere EU-landen. 


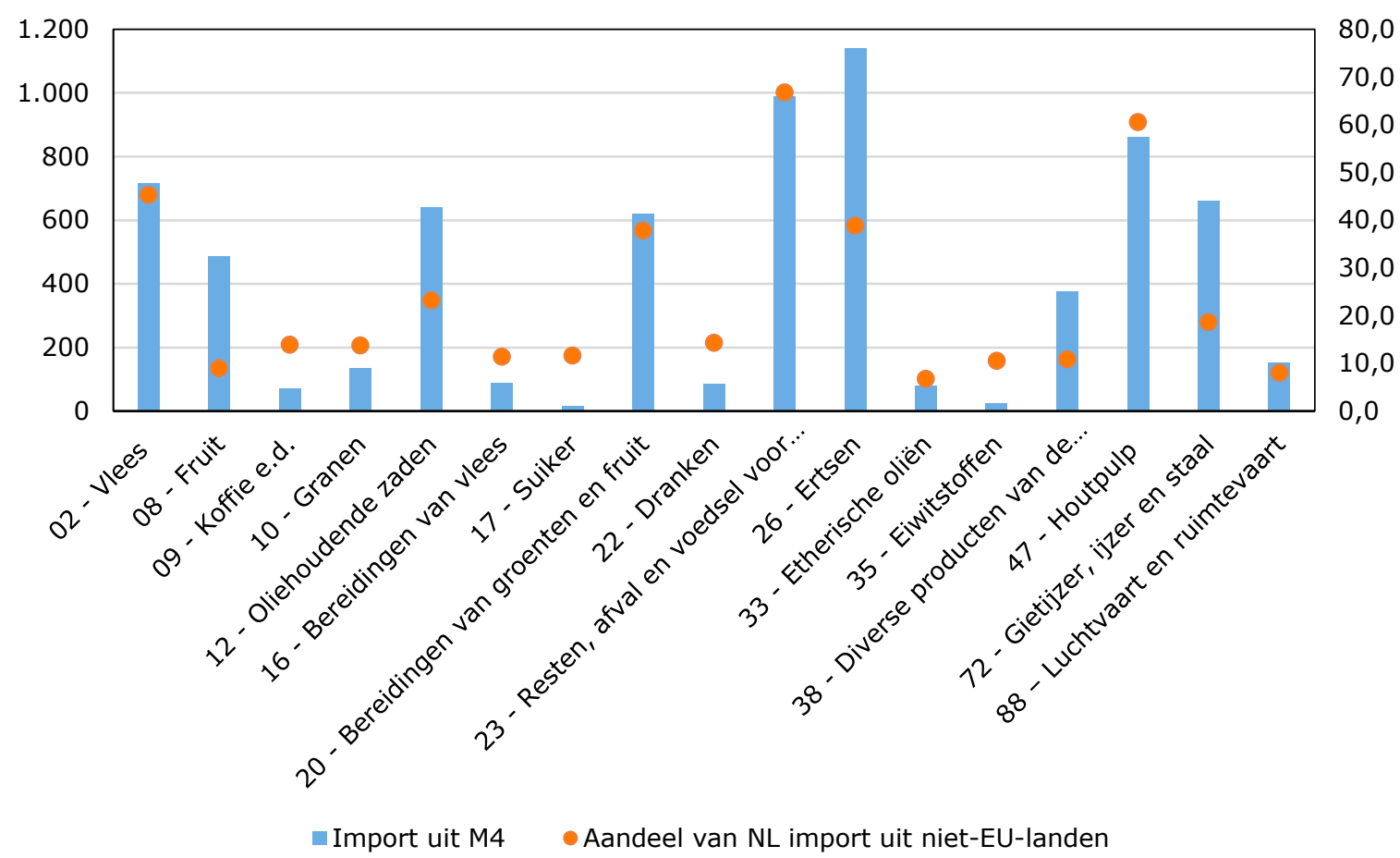

Figuur 2.1 Nederlandse import uit Mercosur-landen (in miljoenen euro's, linkeras; een als percentage van de Nederlandse import uit niet-EU-landen, rechteras) data 2018) a)

a) Deze figuur toont alleen de import uit Mercosur die meer dan 5\% van de totale Nederlandse import uit niet-EU-landen vertegenwoordigt.

Bron: Eurostat COMEXT.

\subsubsection{Wederexport van de import uit Mercosur-landen}

Het is welbekend dat Nederland door zijn geografische ligging, hoogwaardige infrastructuur, efficiëntie van de logistieke dienstverlening en verwerkingscapaciteit een belangrijke doorgangspoort vormt voor de export van niet-EU-landen naar andere EU-lidstaten, vooral naar een ring van landen rond Nederland (met name Duitsland, België, Frankrijk en het Verenigd Koninkrijk). Als gevolg daarvan bestaat een deel van de Nederlandse import uit Mercosur uit transit en/of wederexport ${ }^{2}$ naar de EU-27-markten.

Een voorbeeld hiervan zijn de activiteiten van de toeleveringsketen voor sojabonen, waarbij sojaperserijen sojabonen (4,2 miljoen ton) importeren (waarvan 24\% uit Brazilië) en sojaschroot voor de diervoederindustrie produceren. Daarnaast importeert de Nederlandse diervoederindustrie sojaschroot (2,6 miljoen ton) rechtstreeks uit niet-EU-landen ( $90 \%$ is afkomstig uit Brazilië en Argentinië). De Nederlandse export van sojabonen bedraagt 1 miljoen ton en 3,1 miljoen ton sojaschroot (bijna uitsluitend naar EU-lidstaten); deze hoeveelheid is exclusief mengvoeders die bestaan uit een mengsel van verschillende ingrediënten, waaronder sojaschroot). ${ }^{3}$

Deze cijfers laten zien hoe de import- en exportstromen in een wereldwijd opererende waardeketen met elkaar verbonden zijn, waardoor bedrijven en handelaren uit verschillende landen en ook veel verschillende industriële sectoren met elkaar verbonden zijn. Zo is bijvoorbeeld sojaolie een ander product dat wordt geproduceerd door sojaperserijen en dat onder meer wordt gebruikt in de voedingsindustrie en de chemische industrie. Door de complexiteit van de input- en outputrelaties tussen de verschillende industrieën is het moeilijk om een volledig en betrouwbaar inzicht te geven in

\footnotetext{
2 Transitgoederen zijn goederen die in buitenlandse handen blijven en niet voor de Nederlandse markt bestemd zijn. Ingevoerde goederen die worden (her)verpakt en/of verwerkt voordat ze weer worden geëxporteerd, worden geregistreerd als wederexport.

3 De data betreft de handelsstromen in 2018. Bron: MVO via https://www.mvo.nl/media/handelspolitiek/mvo-soybeaninfographic-final.pdf
} 
de mate waarin de export bestaat uit eerder geïmporteerde grondstoffen en/of halffabrikaten. Uit CBS-gegevens blijkt dat, naast de sojabonen en de producten daarvan, de import van kwaliteitsrundvlees en sinaasappelsap uit Mercosur-landen grotendeels wordt wedergeëxporteerd. ${ }^{4}$

\subsubsection{Nederlandse export naar Mercosur-landen}

Figuur 2.2 hieronder toont de Nederlandse export naar Mercosur van de productcategorieën met een waarde van meer dan 30 miljoen euro in 2018. De belangrijkste productcategorieën zijn minerale brandstoffen (met als belangrijkste onderdeel 'aardolie en olie uit bitumineuze mineralen'), farmaceutische producten (geneesmiddelen) en kernreactoren, stoomketels, machines, toestellen en mechanische werktuigen (hoofdzakelijk bestaande uit een grote verscheidenheid aan machines), gevolgd door optische instrumenten, apparaten en toestellen (met name instrumenten, apparaten en toestellen voor medisch, chirurgisch, tandheelkundig of diergeneeskundig gebruik) en elektrische machines en apparaten.

De Nederlandse export van landbouwproducten en voedingsmiddelen naar Mercosur is bescheiden, met als belangrijkste producten bereid voedsel voor dieren, bereidingen van groenten (voornamelijk gekookte aardappelen, bevroren) en dranken.

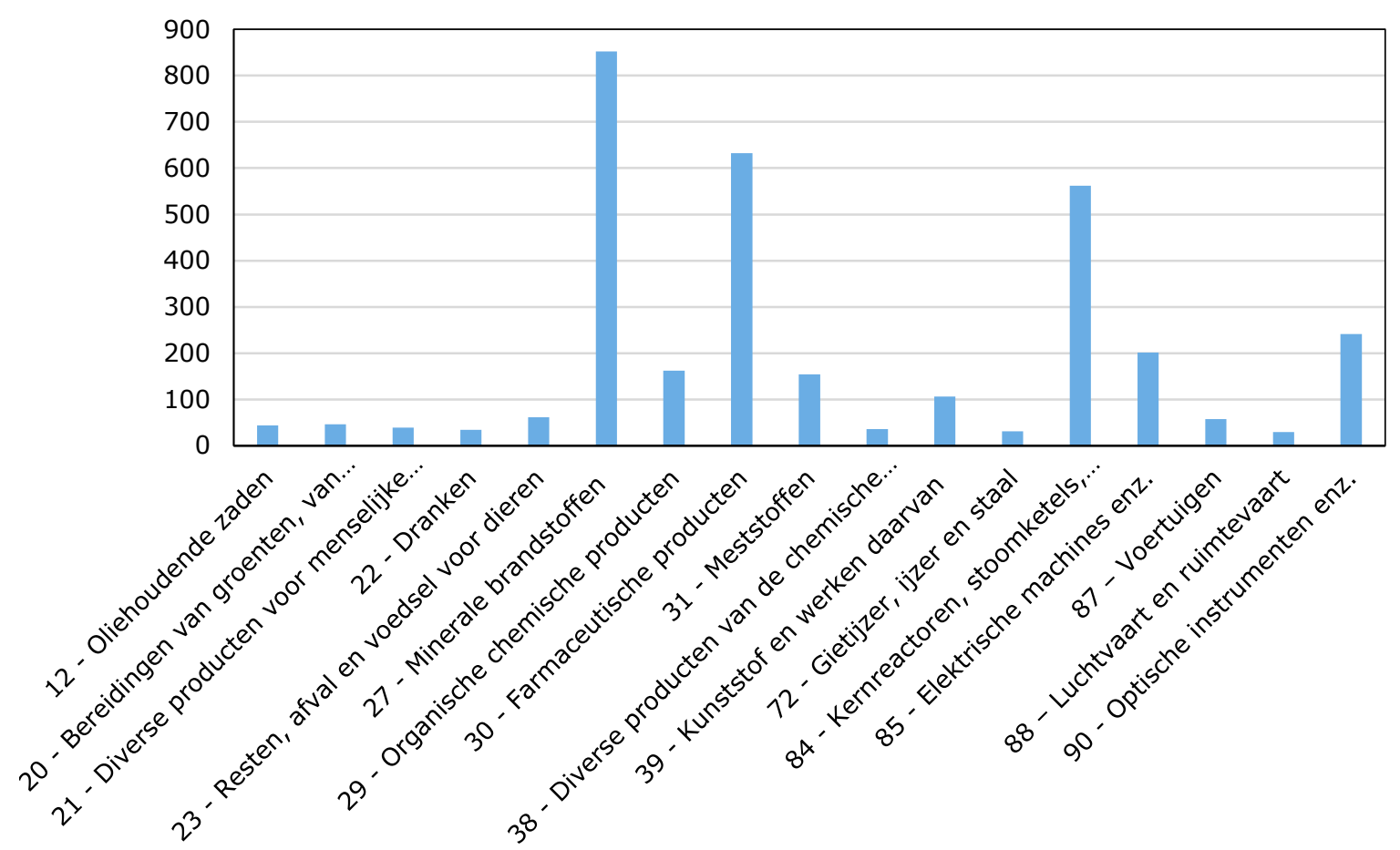

Figuur 2.2 Nederlandse export naar Mercosur-landen (in miljoenen euro's, 2018) a) a) De figuur toont alleen producten met een waarde van 30 miljoen euro en meer. Bron: Eurostat COMEXT.

\footnotetext{
4 Gegevens over de wederexport van Nederlandse import zijn te vinden op CBS Statline (https://opendata.cbs. nl/statline/), maar alleen op een sterk geaggregeerd niveau. Gegevens over de landspecifieke wederexport van de import (bijvoorbeeld uit Brazilië) kunnen pas worden ingezien nadat een speciaal verzoek daartoe bij het CBS is ingediend.
} 


\subsection{Huidige handelsvoorwaarden in de bilaterale handel tussen de EU en Mercosur}

\subsubsection{Tariefstructuren}

Tabel 2.3 geeft een overzicht van de beschermende tarieven van elk van de vier Mercosur-landen en de EU. De invoerrechten waarnaar in de kolom 'Totaal' wordt verwezen, zijn een gemiddelde van alle producten die onder het GS-hoofdstuk 01-97 vallen. De hoofdstukken 01-24 hebben betrekking op 'Landbouw'. De tariefprofielen weergegeven in de tabel hebben betrekking op lijsten voor 2018 (eenvoudig gemiddelde) en 2017 (handelsgewogen gemiddelde). ${ }^{5}$

Tabel 2.3 Toegepaste MFN a) tariefprofielen van Mercosur-landen en van de EU: eenvoudig gemiddelde (S) en handelsgewogen (TW) gemiddelde (in\%)

\begin{tabular}{|c|c|c|c|c|c|c|}
\hline & \multicolumn{2}{|c|}{ Totaal } & \multicolumn{2}{|c|}{ Landbouw } & \multicolumn{2}{|c|}{ Niet-landbouw } \\
\hline & $s$ & TW & $s$ & TW & $s$ & TW \\
\hline Argentinië & 13,6 & 14,4 & 10,3 & 11,9 & 14,2 & 14,9 \\
\hline Paraguay & 9,8 & 7 & 10 & 13 & 9,7 & 6,4 \\
\hline Uruguay & 10,3 & 10,4 & 9,9 & 12,2 & 10,4 & 10,1 \\
\hline
\end{tabular}

a) MFN = meest begunstigde natie. Op grond van de overeenkomsten van de Wereldhandelsorganisatie (WTO) mogen landen geen onderscheid maken tussen hun handelspartners. Volgens de WTO-overeenkomsten is een MFN-tarief (meestbegunstigde natietarief) een algemeen op import toegepast tarief. Uitzonderingen zijn toegestaan, bijvoorbeeld wanneer landen een vrijhandelsovereenkomst tot stand brengen (zie www.wto.org).

Bron: WTO ITC UNCTAD, Wereldtariefprofielen 2019.

De cijfers in tabel 2.3 laten zien dat:

- In het algemeen hebben Mercosur-landen hogere tarieven dan de EU (berekend als 'eenvoudig' en 'handelsgewogen' gemiddelde, zie kolom 'Totaal');

- De EU-tarieven voor landbouwproducten zijn relatief hoog in eenvoudige gemiddelde termen (kolom S onder 'Landbouw'), terwijl het handelsgewogen gemiddelde tarief lager is dan dat van de Mercosur-landen. Dit komt omdat bijna 50\% van de import van landbouwgoederen van de EU met vrijstelling van invoerrechten wordt ingevoerd en elk van de Mercosur-landen slechts een zeer klein percentage van zijn import van landbouwgoederen met vrijstelling van invoerrechten importeert ${ }^{6}$;

- De EU-tarieven voor industriële goederen liggen ver onder die van elk Mercosur-land.

Naast de tarieven als een percentage van de importwaarde kan een invoerrecht worden toegepast in de vorm van een absoluut bedrag in euro's per $\mathrm{kg}$ of ton (het zogeheten specifiek tarief). De EU past een specifiek tarief toe voor veel producten, zoals voor vlees (186 tarieflijnen van de 248 zijn gekoppeld aan een specifiek tarief), zuivel (161 tarieflijnen van de 172 tarieflijnen) en vele andere producten. Desondanks zijn de tarieven van de EU gemiddeld (dus wanneer de tarieven en de specifieke tarieven samen worden genomen) lager dan die van Mercosur-landen, met uitzondering van GS 11 (producten van de meelindustrie), GS 16 (vleesbereidingen), GS 20 (groente- en fruitbereidingen) en GS 24 (tabak) (WTO, 2020).

\footnotetext{
5 Een 'eenvoudig gemiddelde' van de MFN-invoerrechten (MFN = meest begunstigde natie) is gebaseerd op het optellen van alle tarieven voor elke lijn met een import, en dit aantal te delen door het aantal tarieflijnen, waardoor elke tarieflijn evenveel gewicht krijgt, ongeacht de hoeveelheid die onder elke tarieflijn wordt verhandeld. Een 'handelsgewogen' gemiddelde tarief houdt rekening met de waarde van de import van elke tarieflijn. Een eenvoudige manier om het handelsgewogen gemiddelde tarief te berekenen is door de totale tariefinkomsten te delen door de totale waarde van de import.

6 De tarieflijn met het nultarief genereert inderdaad geen tariefinkomsten.
} 


\subsubsection{Tariefcontingenten voor de import}

Naast de tarieven past de EU voor een aantal landbouwproducten importcontingenten toe als onderdeel van haar handelsregeling voor landbouwproducten. In haar bilaterale betrekkingen met Mercosur heeft de EU de Latijns-Amerikaanse landen preferenties toegekend, wat betekent dat een land een importcontingent met verlaagde (of geheel afwezige) invoertarieven tot een maximumhoeveelheid wordt aangeboden. Deze met de Mercosur-landen overeengekomen tariefcontingenten zijn samengevat in tabel 2.4 hieronder.

Tabel 2.4 De momenteel geldende agrarische tariefcontingenten die met Mercosur-landen zijn overeengekomen

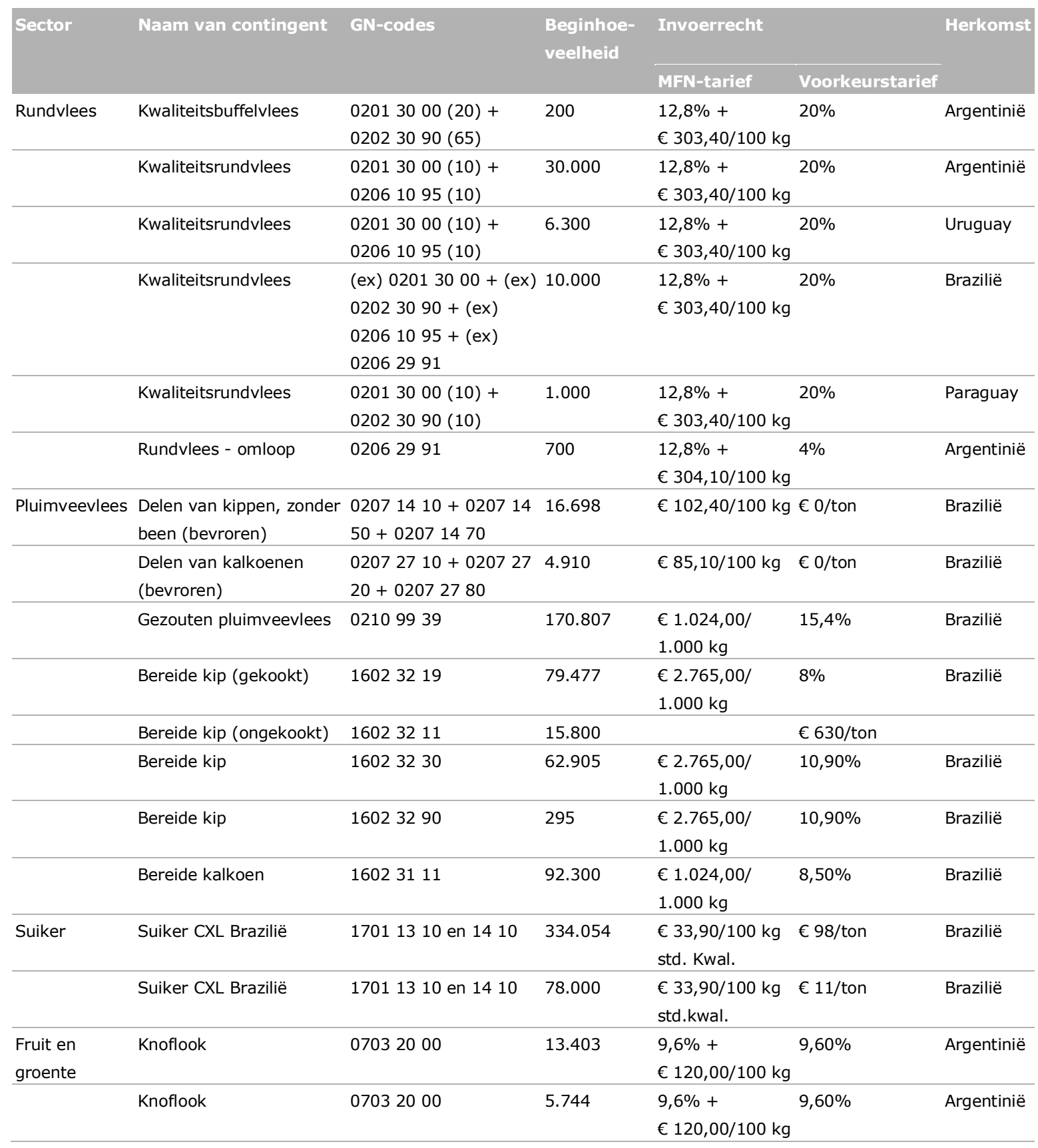

Bron: Websites van de Europese Commissie. ${ }^{7}$ Opm. De tariefcontingenten voor rundvlees en pluimveevlees worden uitgedrukt in gewicht van het vlees zonder been in ton.

\footnotetext{
7 Voor rundvlees: https://ec.europa.eu/info/sites/info/files/food-farming-fisheries/farming/documents/beef-quota_en.pdf. Voor pluimveevlees: https://eur-lex.europa.eu/legal-content/EN/TXT/PDF/?uri=CELEX:32019R0398\&from=EN. Voor suiker: https://eur-lex.europa.eu/legal-content/EN/TXT/?uri=CELEX:02009R0891-20171001
} 
Het cijfervoorbeeld voor kwaliteitsrundvlees als voorbeeld dienen om de waarde te schatten van de toegekende voorkeuren door toepassing van een tariefcontingent. Uit de importgegevens van Eurostat voor 2019 blijkt dat de EU-invoerprijs van kwaliteitsrundvlees uit Argentinië bijna 9.000 euro/ton bedroeg. Onder de MFN-tarieven (meest begunstige natie; most favoured nation) zouden de invoerrechten 4.186 euro/ton $(12,8 \%+3.034$ euro) zijn geweest, dat is $46 \%$ van de importwaarde. Als onderdeel van de hoeveelheid binnen het quotum wordt een importtarief van $20 \%$ in rekening gebracht, waardoor de invoerrechten 1.800 euro/ton bedragen. De preferentiële marge tussen MFN en het tarief binnen het quotum bedraagt dan bijna 2.400 euro/ton.

Tabel 2.5 laat zien dat de tariefcontingenten voor (vers, gekoeld, bevroren) rundvlees volledig worden benut, wat aangeeft dat de handel in deze soorten vlees zelfs aantrekkelijk is buiten het quotum wanneer de volledige (MFN-)invoerrechten moeten worden betaald. De cijfers laten zien dat de handel in de tariefcontingenten bereidingen en conserven van/met pluimveevlees, suiker en knoflook de toegekende preferentiële hoeveelheden niet overschrijdt.

Tabel 2.5 Importhoeveelheden van producten die vallen onder de met Mercosur-landen overeengekomen regelingen voor de tariefcontingenten voor de import in de EU

\begin{tabular}{|c|c|c|c|c|c|c|}
\hline Product & Productbeschrijving & $\begin{array}{l}\text { Mercosur- } \\
\text { exportland }\end{array}$ & $\begin{array}{l}\text { Toegekende } \\
\text { hoeveelheid } \\
\text { binnen het } \\
\text { quotum (ton) }\end{array}$ & \multicolumn{3}{|c|}{$\begin{array}{r}\text { Werkelijke hoeveelheid geïmporteerd } \\
\text { door EU-28 } \\
\text { (in ton) }\end{array}$} \\
\hline \multirow[t]{4}{*}{ Rundvlees } & Kwaliteitsbuffelvlees & & 200 & 1.281 & 1.891 & 2.262 \\
\hline & Kwaliteitsrundvlees & Argentinië & 30.000 & 37.015 & 46.095 & 48.750 \\
\hline & & Brazilië & 10.000 & 22.917 & 22.435 & 20.932 \\
\hline & & Paraguay & 1.000 & 3.857 & 2.951 & 2.432 \\
\hline \multirow[t]{6}{*}{ Pluimveevlees } & $\begin{array}{l}\text { Delen van kippen, } \\
\text { zonder been } \\
\text { (bevroren) }\end{array}$ & Brazilië & 16.698 & 41.884 & 76.313 & 52.874 \\
\hline & Bereide kip (gekookt) & Brazilië & 79.477 & 70.105 & 56.304 & 59.946 \\
\hline & $\begin{array}{l}\text { Bereide kip } \\
\text { (ongekookt) }\end{array}$ & Brazilië & 15.800 & 9.999 & 3.337 & 3.075 \\
\hline & Bereide kip & Brazilië & 62.905 & 38.431 & 12.535 & 3.650 \\
\hline & Bereide kip & Brazilië & 295 & 21 & 0 & 0 \\
\hline & Bereide kalkoen & Brazilië & 92.300 & 37.755 & 5.694 & 653 \\
\hline
\end{tabular}

Bron: zie tabel 2.4; De werkelijke importhoeveelheden van Eurostat in 2017, 2018 en 2019.

Opm. De import van suiker uit Brazilië heeft betrekking op GN 17011410/90 (ruwe suiker bestemd om te worden geraffineerd/andere ruwe suiker) en 17019910 (witte suiker in droge toestand).

\subsection{Verwachtingen van mogelijke effecten van wijzigingen in de handelsvoorwaarden als gevolg van het principeakkoord}

Het principeakkoord omvat verlagingen van de importtarieven, uitbreiding van de preferentiële importquota en regels rond normen en technische voorschriften die van invloed zijn op de handel tussen de EU en Mercosur. Daarnaast heeft het akkoord betrekking op de naleving van de regels over 
de erkenning van intellectuele-eigendomsrechten, inclusief geografische aanduidingen, over diensten, overheidsopdrachten en mededinging. ${ }^{8}$ Volgens het document van de Commissie waarin het principeakkoord wordt samengevat (EC, 2020), zal Mercosur 91\% van zijn import uit de EU volledig liberaliseren gedurende een overgangsperiode van maximaal 10 jaar voor de meeste producten en maximaal 15 jaar voor enkele van de meest gevoelige producten binnen Mercosur. De EU zal $92 \%$ van haar import uit Mercosur liberaliseren gedurende de overgangsperiode van 10 jaar (zie paragraaf 3.1 voor meer informatie).

Wat de landbouwgoederen betreft, zal de EU $82 \%$ van de import van landbouwproducten liberaliseren, waarbij op de resterende import gedeeltelijke liberaliseringsverplichtingen van toepassing zijn, met inbegrip van tariefcontingenten voor gevoeligere producten. In de volgende subparagraaf komen de overeengekomen tariefcontingenten voor landbouwproducten nader aan de orde en worden ze in de juiste context geplaatst, zodat er een voorlopige beoordeling gemaakt kan worden van de mogelijke effecten op de EU-markt. Daarnaast vatten we gesprekken met vertegenwoordigers van het bedrijfsleven samen waarin zij aangeven wat hun verwachtingen zijn van dit akkoord, met name met betrekking tot de artikelen in het akkoord die verwijzen naar normen en andere niet-tarifaire maatregelen met invloed op de handel.

\subsubsection{Toekomstige tariefcontingenten}

Tabel 2.6 bevat een vergelijking van de momenteel geldende tariefcontingenten met de in het principeakkoord genoemde hoeveelheden binnen het quotum die aan Mercosur-landen worden toegekend (EC, 2020). Toekomstige tariefcontingenten worden aan Mercosur toegekend als groep. Er zullen geen nieuwe individuele tariefcontingenten per land komen, behalve voor suiker. In de openbaar beschikbare informatie wordt geen gedetailleerde productbeschrijving gegeven van het product waarop het quotum van toepassing is; In plaats daarvan worden er brede productcategorieën gedefinieerd. Verder zouden de tariefcontingenten afhankelijk kunnen zijn van bijvoorbeeld de naleving van de EU-regelgeving over dierenwelzijn. ${ }^{9}$ Zulke voorwaarden zijn, indien van toepassing, nog niet gepubliceerd. Met deze voorbehouden toont de tabel het volgende op grond van het akkoord:

- Voor rundvlees biedt de EU Mercosur een extra tariefcontingent van 75.000 ton (productgewicht), waardoor het totale tariefcontingent voor rundvlees wordt uitgebreid tot 122.654 ton.

De import van (kwaliteits)rundvlees uit Mercosur-landen was de afgelopen jaren goed voor 90-100 duizend ton (zie tabel 2.5), wat meer is dan het quotumniveau van het huidige tariefcontingent. Dit suggereert dat Mercosur-landen in staat zijn om kwaliteitsrundvlees uit te voeren boven het contingent, ook al worden voor de hoeveelheid die het contingent overschrijdt invoerrechten in rekening gebracht. Daarom zal het uitgebreide tariefcontingent hoogstwaarschijnlijk leiden tot een toename van de import van meer dan 20.000 ton rundvlees (het verschil tussen de huidige import en het nieuwe tariefcontingent), aangezien Mercosur-landen in staat zijn kwaliteitsrundvlees tegen concurrerende prijzen aan te bieden en aangenomen dat er in de EU vraag is naar dit type rundvlees. Uiteraard is alle import uit Mercosur afhankelijk van het voldoen aan de EU-normen, waaronder voedselveiligheid en SPS-verordeningen.

- Voor pluimveevlees wordt het tariefcontingent uitgebreid met 153.000 ton. Dit brengt het totale contingent voor pluimveevlees op 590.000 ton.

De afgelopen jaren was er een import van 250-300 duizend ton. Dat is een daling ten opzichte van de voorgaande jaren, te wijten aan de lagere vraag in de EU naar Braziliaans vlees als gevolg van de bezorgdheid over de voedselveiligheid (DG Sante, 2018); Foodnavigator 2018). ${ }^{10}$ Brazilië is een zeer concurrerende pluimveevleesproducent (Van Horne, 2019). Afhankelijk van hoe snel de Braziliaanse vleessector en de autoriteiten de EU ervan kunnen overtuigen dat Braziliaans pluimveevlees aan de Europese voedselveiligheidseisen voldoet, mag worden aangenomen dat Brazilië in staat is meer

\footnotetext{
8 Zie de website van het DG voor Handel voor meer informatie over elk van de onderwerpen waarop het principeakkoord van toepassing is: https://trade.ec.europa.eu/doclib/press/index.cfm?id=2048.

9 Als voorbeeld kan worden gerefereerd naar een aan een contingent gekoppelde voorwaarde voor de import van eieren uit Oekraïne, als onderdeel van het handelsakkoord tussen de EU en Oekraïne. In dit akkoord wordt bepaald dat de import van eieren uit Oekraïne alleen vrijgesteld is van invoerrechten als de kippen in overeenstemming met de EU-normen worden gehouden.

${ }^{10}$ Zie bijvoorbeeld https://www. foodnavigator.com/Article/2018/04/23/EU-ban-on-Brazil-imports. De daling van de import uit Brazilië in 2018 en 2019 was het gevolg van het schandaal carne fraca ('zwak vlees'). Braziliaans pluimveevlees was besmet met salmonella en veel EU-Ianden schortten de import uit Brazilië op.
} 
naar de EU uit te voeren dan de afgelopen jaren het geval was. De EU-import uit Brazilië is echter vervangen door pluimveevlees uit de Oekraïne. Oekraïne is ook internationaal een sterke concurrent, en Oekraïne profiteert van een voorkeursbehandeling als onderdeel van het vrijhandelsakkoord tussen de EU en Oekraïne. Het is dus nog maar de vraag of Brazilië de toegekende voorkeursbehandeling ten volle kan benutten. Bij een geschatte jaarlijkse consumptie in de EU van 15 miljoen ton (voor 2018: AVEC, 2020), zou de import uit Brazilië op het niveau van het nieuw toegekende tariefcontingent $4 \%$ bedragen. De consumptie van pluimveevlees in de EU zal naar verwachting de komende 10 jaar gestaag toenemen (EC, 2019).

- Varkensvlees krijgt een tariefcontingent van 25.000 ton (karkasgewicht) toegekend. Dit is een nieuwe preferentie voor Mercosur-leveranciers.

Momenteel vindt er vrijwel geen import van varkensvlees door de EU-lidstaten uit Mercosur-landen plaats. De import van varkensvlees in de EU moet vrij zijn van ractopamine, een diervoedertoevoeging die in de EU verboden is. Brazilië claimt ractopaminevrij varkensvlees te produceren, maar bij EU-inspecties in de afgelopen jaren werd deze stof nog steeds aangetroffen in een aanzienlijk deel van de monsters die zijn genomen bij slachtvarkens. Dit leidde tot de conclusie dat het aanwezige systeem nog niet degelijk genoeg is om te garanderen dat er geen ractopamine wordt gebruikt (Voedsel-en Veterinair Bureau, 2013); mondelinge informatie van varkensmarktexpert).

- De import van suiker wordt geregeld via een tariefcontingent voor geraffineerde suiker voor Brazilië (waarbij het tarief binnen het quotum voor een deel van het huidige tariefcontingent wordt verlaagd) en voor Paraguay (een relatief klein, nieuw contingent).

$\mathrm{Bij}$ het tariefcontingent voor Brazilië is de verlaging van het tarief binnen het quotum relatief klein en is er geen uitbreiding van de overeengekomen hoeveelheid binnen het quotum, terwijl het nieuwe tariefcontingent voor Paraguay bescheiden is. Daarom is de verwachte extra instroom van suiker uit Mercosur klein en zullen de verwachte effecten op de suikermarkt van de EU dat ook zijn.

- De import van ethanol wordt gereguleerd via twee tariefcontingenten, één voor de chemische sector (bijv. voor de productie van bioplastics) en één voor andere gebruikers van ethanol, zoals voor brandstof voor het wegtransport (in mengsels met fossiele brandstoffen).

Verwacht wordt dat de vraag naar ethanol in de EU in het komende decennium zal toenemen, aangemoedigd door de EU-doelstelling om het gebruik van hernieuwbare energie in de transportsector te verhogen van $10 \%$ in 2020 tot $14 \%$ in 2030. Aangezien de EU-beleidskaders grenzen stellen aan het gebruik van landbouwgrondstoffen (zoals tarwe en maïs) voor ethanol en biodiesel, wordt verwacht dat de toename van de vraag naar ethanol zal worden ondersteund door een toename van de import (OESO-FAO, 2020); EC, 2019; USDA, 2019).

- Nieuwe tariefcontingenten worden toegekend, voor rijst, honing, suikermaïs en zuivelproducten. De zuivelquota (voor kaas, melkpoeder en babymelkpoeder) zijn wederzijds, wat betekent dat de EU-exporteurs naar Mercosur een vergelijkbare hoeveelheid binnen het quotum hebben die met vrijstelling van invoerrechten wordt toegekend. ${ }^{11}$ De huidige export van de EU naar Mercosur ligt onder de hoeveelheden binnen het quotum die Mercosur aan EU-exporteurs toekent, wat ook te wijten is aan de strenge etiketteringsvoorschriften en het Braziliaanse systeem van exportlijsten, waarbij gedetailleerde inspecties op locatie bij de bedrijven vereist zijn (zie ook Van Berkum, 2015). Als de kwalificatieprocedures voor de export naar Mercosur zouden worden versoepeld, zou de export uit de EU van producten met een hoge toegevoegde waarde zoals kaas en babymelkpoeder naar Mercosur aantrekkelijk zijn, hoewel het een kleine markt zal blijven in verhouding tot de totale export van de EU (en Nederland) naar derde landen.

\footnotetext{
${ }^{11}$ De zuiveltariefcontingenten zijn de enige bilaterale tariefcontingenten die in het kader van het akkoord zijn ingevoerd.
} 
Tabel 2.6 Producten die onder de regelingen over tariefcontingenten voor import in de EU vallen: huidige tariefcontingenten vergeleken met toekomstige tariefcontingenten volgens het handelsakkoord tussen de EU en Mercosur

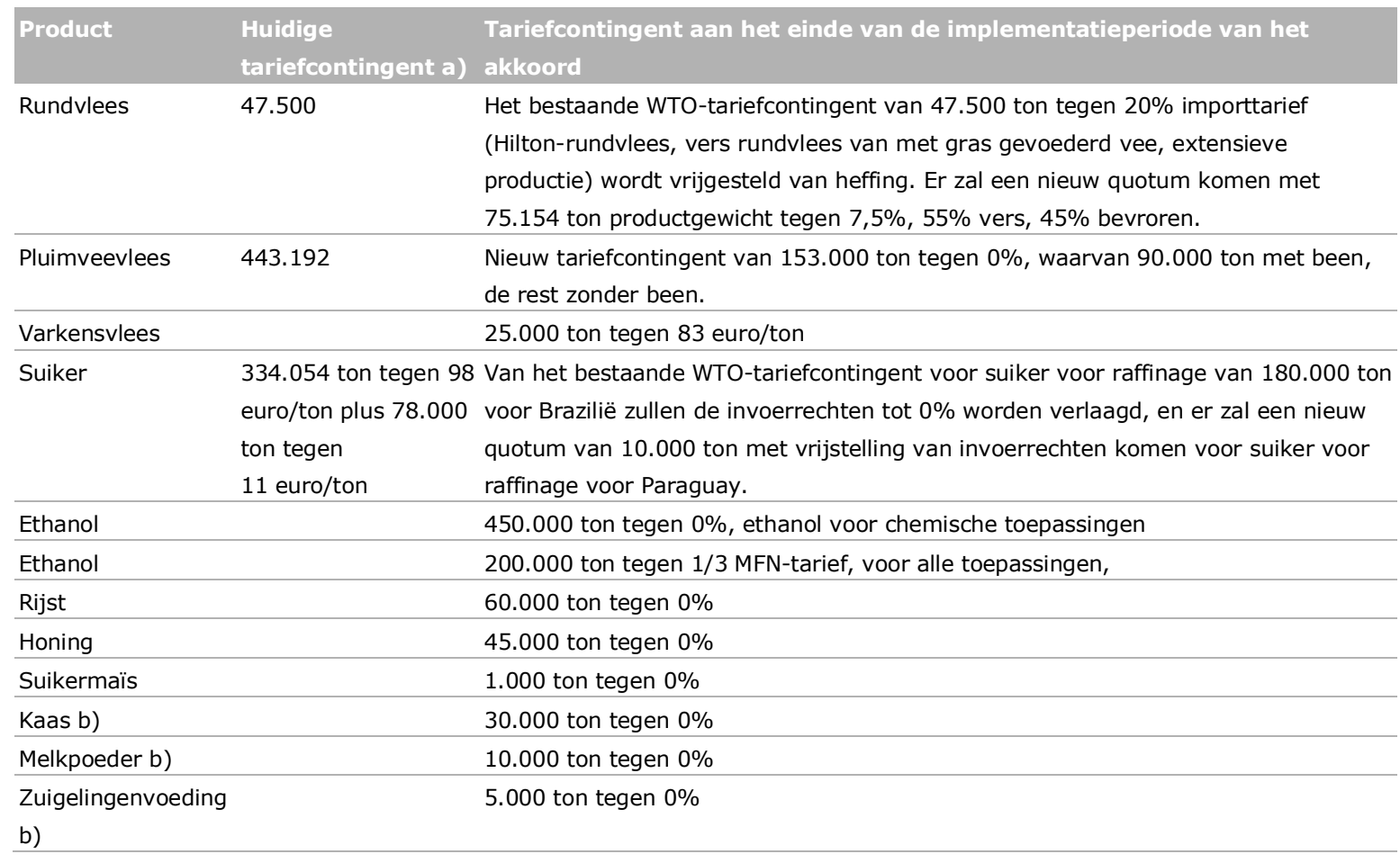

a) de huidige tariefcontingenten die in verdere productcategoriedetails met voorwaarden binnen het quotum worden gespecificeerd, worden in tabel 2.4 toegelicht; b) Wederzijdse tariefcontingenten.

Bron voor toekomstige tariefcontingenten: EC, samenvatting van de akkoordtekst juli 2019.

https://trade.ec.europa.eu/doclib/docs/2019/june/tradoc_157964.pdf.

2.3.2 Voornaamste niet-tarifaire maatregelen die van invloed zijn op de bilaterale handel tussen de EU en Mercosur en de verwachtingen van de stakeholders over de wijze waarop het akkoord de handelsbarrières als gevolg van niettarifaire maatregelen zou kunnen verminderen

Niet-tarifaire maatregelen (NTM's) zijn beleidsmaatregelen, naast tarieven of tariefcontingenten, die direct of indirect economische effecten kunnen hebben op de handelsstromen tussen landen. NTM's bestaan uit zogeheten 'achter de grens'-regelgeving die van invloed is op de handel en veel verschillende vormen kan aannemen. Hieronder bevinden zich de sanitaire en fytosanitaire normen (SPS, sanitary and phytosanitary standards) en technische handelsbarrières (TBT, technical barriers to trade) die betrekking hebben op respectievelijk de toepassing van de verordeningen over voedselveiligheid en de gezondheid van dieren en planten, alsmede de technische verordeningen, normen, test- en certificeringsprocedures die (door de WTO-overeenkomst) geacht worden te zijn gecreëerd om legitieme doeleinden te verwezenlijken, zoals de bescherming van de consument of van het milieu. ${ }^{12}$ Hoewel de WTO-overeenkomsten over sanitaire en fytosanitaire normen en technische handelsbarrières een algemene basis bieden voor een gelijk speelveld, wordt in de overeenkomsten ook erkend dat WTO-leden volgens hun eigen regelgevende autoriteit legitieme belangen beschermen. Daarom zijn de SPS- en TBT-maatregelen van de EU- en Mercosur-landen niet (perfect) op elkaar afgestemd of geharmoniseerd, wat in het geval van bilaterale handel kosten met zich meebrengt om aan de eisen van een handelspartner te voldoen.

Hieronder tonen we aan de hand van informatie uit de EU-Databank Markttoegang (MADB) kwesties op het gebied van SPS en TBT die relevant zijn voor de beoordeling van de effecten van het handelsakkoord tussen de EU en Mercosur. De MADB rapporteert over de SPS- en TBT-kwesties en andere kwesties in de bilaterale handel met derde landen die onopgelost zijn en dus de handel vanuit

\footnotetext{
${ }^{12}$ Zie voor de principes in WTO-overeenkomsten: https://www.wto.org/english/tratop_e/sps_e/spsund_e.htm
} 
het perspectief van de EU belemmeren. Het algemene doel van de MADB is om meer transparantie te brengen in de handelskwesties waarmee EU-exporteurs worden geconfronteerd en om de inspanningen om deze op te lossen te vergemakkelijken.

De MADB bestaat uit twee gegevenssets: de TBT-database en de SPS-database ${ }^{13}$ In de TBT-database worden zeven categorieën maatregelen gedefinieerd die verband houden met de traditionele handelsbeleidsinstrumenten (tarieven en invoerrechten, handelsbeschermingsinstrumenten), andere exportgerelateerde maatregelen (investeringsgerelateerde barrières, intellectuele-eigendomsrechten, dienstengerelateerde en overige maatregelen) en NTM's. Zowel in de TBT-database als in de SPSdatabase wordt informatie verstrekt op basis van het type maatregel, het product en de exportbestemming.

Er moet rekening worden gehouden met verschillende beperkingen van de MADB. De database heeft te lijden onder een vertekend beeld door selectiviteit bij de melding van de handelsbarrières (ofwel door bedrijven, hun vertegenwoordigende organisaties of door overheidsfunctionarissen). Alleen gemelde handelsbarrières zijn opgenomen, waarbij deze na een evaluatie door de EC worden vermeld. De MADB verstrekt geen informatie over het belang van de gemelde handelsbarrières, aangezien er geen informatie beschikbaar is over de omvang van de negatieve invloed ervan op het handelsvolume en/of de handelswaarde. De informatie is echter nuttig om te wijzen op handelsbarrières die relevant zijn voor EU-exporteurs, om aan te geven met welke problemen EU-exporteurs zijn geconfronteerd bij de toelevering van buitenlandse markten.

De MADB laat een verscheidenheid aan handelsbarrières waar EU-exporteurs tegenaan lopen bij de handel met Mercosur, van de claim van onvoldoende bescherming van intellectuele-eigendomsrechten (IPR) en geografische aanduidingen tot niet-automatische importvergunningen met lange goedkeuringsprocedures, verschillen in de etiketterings-, markerings- en verpakkingseisen voor wijn, en de eisen die vooraf aan diensten worden gesteld (in het bijzonder voor de sectoren techniek, telecommunicatie en verzekeringen). Wat de SPS-maatregelen betreft, hebben EU-exporteurs van planten en plantaardige producten een klacht ingediend dat de PRA-procedures die nodig zijn om de Braziliaanse markt te betreden, zeer lang duren. Een PRA is de belangrijkste fytosanitaire eis die het Braziliaanse ministerie van Landbouw stelt aan het verlenen van vergunningen voor de import van planten en producten daarvan in Brazilië. Er zijn ernstige vertragingen bij het uitgeven van PRA's, in sommige gevallen 10 jaar. De handelsbetrekkingen van de EU-tuinbouwsector (groenten en fruit en bloementeelt) met Brazilië worden naar verwachting beter door het versnellen van zulke procedures (Van Berkum, 2015). Bovendien wordt de achterstand bij de evaluaties van de inspectie- en certificatiesystemen van EU-lidstaten door het Braziliaanse ministerie van Landbouw beschouwd als een ernstig obstakel voor de export van EU-vlees en -zuivel naar dat land. In de handel met Argentinië zijn de belangrijkste gemelde knelpunten het gebrek aan bescherming van de intellectueleeigendomsrechten en de niet-automatische importvergunningenprocedures die gelden voor een uitgebreide lijst van producten (zoals chemische stoffen en machines) en die meer administratief werk en dus hogere handelskosten met zich meebrengen (meer details zijn te vinden op http://madb.europa.eu/madb/indexPubli.htm).

Bovengenoemde handelsbarrières kwamen aan de orde in gesprekken met vertegenwoordigers van Nederlandse bedrijven in Nederland en Brazilië. ${ }^{14}$ Deze gesprekken - soms telefonisch, soms via

\footnotetext{
${ }^{13}$ Hoewel de database van handelsbarrières en de SPS-database elkaar tot op zekere hoogte overlappen, geven ze vanuit het perspectief van de EU-exporteurs verschillende soorten informatie over NTM's aan. De TBT-database verzamelt de klachten die individuele EU-exporteurs, groepen of verenigingen van producenten of de EU-lidstaten bij de EC melden. De klachten moeten daarbij duidelijk aantonen dat de desbetreffende maatregel niet in overeenstemming is met de internationale regels en commerciële schade toebrengt aan de Europese activiteiten, hetzij binnen de EU, hetzij in derde landen. Na een onderzoek door de EC worden de relevante maatregelen opgenomen in de database van handelsbarrières. De SPS-database is daarentegen niet gebaseerd op individuele klachten. De SPS-database bevat informatie die is gemeld door de agrifood-industrie, de EU-lidstaten en de diensten en de delegaties van de EC, en omvat ook relevante SPSmeldingen van de WTO.

${ }^{14}$ Het onderzoeksteam heeft door middel van een mix van schriftelijke bijdragen en gesprekken informatie ontvangen van 22 bedrijven. Daaronder waren vier Nederlandse dochterondernemingen in Brazilië, maar helaas geen antwoorden van bedrijven in andere Mercosur-landen, en 10 vertegenwoordigende organisaties voor het bedrijfsleven. Aangezien het aantal gesprekken beperkt was, kunnen de gemelde inzichten niet als volledig representatief worden beschouwd voor de gehele Nederlandse bedrijfssector die ervaring heeft met het zakendoen in de Mercosur-landen.
} 
e-mail als antwoord op een gestructureerde lijst van vragen - hebben tot een aantal belangrijke constateringen geleid.

In de eerste plaats hebben de stakeholders gewezen op de Nederlandse handelsstructuur, die van oudsher gericht is op Duitsland en andere nabije landen in Europa. Nederland heeft geen culturele banden of historische handelsbetrekkingen met de vier Mercosur-landen. In combinatie met de afstand en de taalbarrières betekent deze handelsstructuur dat de huidige belangstelling van Nederlandse bedrijven voor de Mercosur-markten vrij beperkt is. Deze factoren zijn meer bepalend dan het ontbreken of bestaan van een handelsakkoord. Zolang bedrijven hun omzet en winst relatief dichtbij kunnen realiseren, zijn ze over het algemeen niet geneigd om veel tijd en moeite te steken in het uitbreiden van activiteiten op grotere afstand. Wil men de kansen voor Nederlandse bedrijven op de Mercosur-markten en de handelsstromen vergroten, dan is een handelsakkoord op zich niet voldoende en moet het worden aangevuld met andere handelsbevorderende activiteiten.

Nederlandse bedrijven die in het verleden daadwerkelijk het besluit hebben genomen om actief te worden op de Mercosur-markten, ondervinden over het algemeen problemen met de juridische en fiscale situatie in die landen. De markten worden beschreven als 'vrij complex', met name Brazilië. Sommige ondernemers hebben ook aangegeven dat zij de export hebben stopgezet vanwege het gebrek aan handelsbevordering en de hoge transactiekosten. Met name het midden- en kleinbedrijf (mkb) lijkt door deze kwesties te worden ontmoedigd.

Als we kijken naar de verschillen tussen de sectoren, is het duidelijk dat Nederlandse industriële bedrijven de huidige importtarieven van Mercosur-landen als de belangrijkste handelsbarrière zien. Specifiek voor Brazilië wordt vermeld dat industriële bedrijven met een aanzienlijke (potentiële) omzet vaak de voorkeur geven aan het openen van een productiefaciliteit in Brazilië in plaats van aan het exporteren vanuit Nederland, om zo de aanzienlijke importtarieven te omzeilen. Aangezien de tarieven in het kader van het handelsakkoord voor een groot deel zullen worden afgeschaft, is er een duidelijk aanwezig potentieel voor industriële goederen die momenteel door de tarieven worden belemmerd.

De Nederlandse handel in diensten met Mercosur is bescheiden. Uit de weinige reacties van de dienstensector blijkt dat vooral landen met banden met de regio (Spanje, Italië, Frankrijk) actief zijn in Mercosur. Nabijheid is bij diensten meestal nog belangrijker dan bij goederen. Eveneens een belangrijk punt is dat specifieke plannen voor diensten nog niet openbaar zijn, zodat bedrijven weinig concreet inzicht hebben in echte openstelling van de markten.

Bedrijven in de landbouwsector wijzen meer op maatwerkprocedures en -normen als de belangrijkste belemmerende factoren voor de handel. Het handelsakkoord zal bepalingen bevatten met betrekking tot een proces van werken aan gemeenschappelijke normen, maar het valt nog te bezien in hoeverre zo'n situatie met gemeenschappelijke normen daadwerkelijk zal worden bereikt, aangezien de huidige openbare tekst van het akkoord een proces beschrijft dat gericht is op samenwerking om gemeenschappelijke normen te bereiken, in plaats van aan te geven welke doelstellingen zullen worden bereikt en binnen welke termijn. Daarom is het verre van zeker dat dit handelsakkoord de belangrijkste barrière zal wegnemen, die door de vertegenwoordigers van de landbouwsector is genoemd.

In termen van importconcurrentie is met name de vleessector bezorgd over de effecten op de markt die extra import uit Mercosur (als gevolg van de uitgebreide preferentiële tariefcontingenten) kan hebben. Vertegenwoordigers van het bedrijfsleven vrezen dat een toename van de import zeer waarschijnlijk een negatief effect zal hebben op de prijs voor de vleesrundvee- en pluimveehouders in de EU. Tegelijkertijd kunnen de effecten op de prijs enigszins worden afgezwakt, aangezien pluimveevlees bevroren wordt ingevoerd (voor gebruik door de voedselverwerkende en foodserviceindustrie) en niet in het verse segment mag worden verkocht. In de gesprekken werd gewezen op incidenten waarbij rundvlees-, pluimveevlees- en varkensvleesproducenten uit de Mercosur-landen niet voldeden aan de EU-voedselveiligheidseisen, wat zou wijzen op systematische tekortkomingen in de tracerings- en opsporingssystemen van de Mercosur-landen om de voedselveiligheid te garanderen. Als deze problemen blijven aanhouden, zou dat de verwachte toename van de import van vlees uit de Mercosur-landen als gevolg van dit akkoord afremmen. 
De reacties van Nederlandse bedrijven met dochterondernemingen in Brazilië zijn positief ten aanzien van het akkoord, met name vanwege de verlaging van de importtarieven, de belastingen en de kosten voor handelsfacilitering (versoepeling van de import uit de EU naar Mercosur). Verder is er de verwachting dat de SPS- en TBT-hoofdstukken van het akkoord zullen aanzetten tot een betere afstemming van de Braziliaanse goederen (met name landbouwproducten) op de EU-normen (waardoor de export vanuit Mercosur naar de EU zal worden aangemoedigd). Er wordt echter aangenomen dat verbeteringen op deze gebieden tijd zullen vergen, wat suggereert dat de waargenomen marktkansen slechts langzaam zullen worden benut. 


\title{
3 Effecten van het handelsakkoord op de Nederlandse economie
}

\subsection{Beschrijving van de veronderstelde scenario's, de gebruikte gegevens en de toegepaste verlagingen van de NTM-handelskosten}

\begin{abstract}
Het effect van het Mercosur-akkoord wordt gekwantificeerd aan de hand van het macro-economische model MAGNET (Woltjer et al. 2014). Het MAGNET-model is een multiregionaal, multisectoraal, berekenbaar algemeen evenwichtsmodel (CGEmodel) gebaseerd op de neoklassieke microeconomische theorie (Nowicki et al. 2009, Van Meijl et al. 2006, Woltjer et al. 2014). De kern van de MAGNET-database is de GTAP-dataset (Aguiar et al. 2019). MAGNET gaat uit van perfecte concurrentie, wat betekent dat producenten prijsnemers zijn. Bovendien wordt ervan uitgegaan dat de producenten de goedkoopste combinatie van onvolkomen vervangbare arbeid, kapitaal, grond, natuurlijke hulpbronnen en tussenproducten kiezen. De kern van MAGNET is een input-output model, dat industrieën in toegevoegde-waardeketens verbindt van primaire goederen, via telkens hogere stadia van tussentijdse verwerking, naar de eindassemblage voor consumptie van goederen en diensten. Naast de productie- en dienstenmarkten zijn de landbouw- en voedingsmarkten in MAGNET verder verfijnd en wordt ervan uitgegaan dat internationaal verhandelde producten gedifferentieerd worden naar land van herkomst (Armington 1969).
\end{abstract}

Een onmisbaar onderdeel van dit onderzoek is het modelleren van de productiefactormarkten, inclusief grond en arbeid. MAGNET omvat een grondaanbodfunctie (Van Meijl et al. 2006, Dixon et al. 2016) die de relatie tussen het totale aanbod aan landbouwgrond en de werkelijke grondprijs specificeert gegeven beperkingen in verband met biofysische beschikbaarheid (potentiële oppervlakte van geschikte grond) en institutionele factoren (agrarisch en stedelijk beleid, natuurbehoud). In MAGNET worden de factormarkten onderverdeeld (gesegmenteerd) in agrarische en niet-agrarische arbeid en kapitaal. Dit weerspiegelt het empirische bewijs voor imperfecte arbeidsmobiliteit (De Janvry et al. 1991), en is dus een verbetering ten opzichte van andere CGE-modellen die uitgaan van perfecte mobiliteit.

MAGNET is een mondiaal model, dat macro-economische en sectorale effecten vastlegt, en zoals bij alle modellen is het niet mogelijk om de hele economie perfect na te bootsen. Daarom moeten er bepaalde voorbehouden worden gemaakt, zoals het feit dat grondstoffen en sectoren verzamelingen zijn. De sector varkensvlees en ander wit vlees is bijvoorbeeld een verzamelsector die naast varkensvlees ook konijnenvlees en andere soorten vlees bevat. Bovendien berust de database van dit mondiale model op diverse bronnen van officiële statistieken, die soms kunnen verschillen van bronnen op microniveau als gevolg van verschillende factoren zoals vertrouwelijkheid. Zo zijn bijvoorbeeld de gegevens over de mondiale ethanolproductie afkomstig van het Internationaal Energieagentschap (IEA), dat voor ethanol in Nederland geen enkele productie vermeldt. De modellering is afhankelijk van de gegevensinvoer, en daarom wordt de ethanolproductie niet gemodelleerd voor Nederland. ${ }^{15}$

In het kader van deze beoordeling wordt een hypothetische situatie gesimuleerd waarin het Mercosurakkoord wordt verondersteld te zijn geratificeerd en vanaf 2020 te zijn geïmplementeerd. Het akkoord zou binnen 15 jaar tot volledige implementatie komen, wat betekent dat alle gefaseerde wijzigingen van de markttoegang (tarieven en tariefcontingenten) tegen die tijd volledig zijn ingevoerd. Daarom houden we in het model rekening met de economische veranderingen in de periode tussen 2020 en 2035. Voor het eerste jaar 2020 gaan we uit van een pre-coronascenario om de economische effecten

\footnotetext{
${ }^{15}$ Aangezien er dus geen productiegegevens voor ethanol zijn, is er geen maatstaf voor de blootstelling aan de handel in ethanol beschikbaar en zullen de resultaten voor de productie en de veranderingen in de arbeidscomponent van de toegevoegde waarde nul zijn.
} 
van het Mercosur-akkoord niet te vertroebelen met de complexe, dynamische en grotendeels onzekere economische effecten van de coronasituatie. Bovendien houden wij rekening met de implementatie van de Economische Partnerschapsovereenkomst tussen de EU en Japan ((EPA EU-Japan), de diepe en brede vrijhandelsruimte (DCFTA) tussen de EU en Oekraïne en de brede economische en handelsovereenkomst (CETA) tussen de EU en Canada. Om de effecten van het Mercosur-akkoord zo goed mogelijk te isoleren, maken we een andere hypothetische, vereenvoudigde veronderstelling, namelijk dat het Verenigd Koninkrijk blijft deelnemen aan een gedeelde markt met de EU-27 (27 leden). ${ }^{16}$ Met deze opzet modelleren we twee scenario's: het basisscenario, wat het 'business as usual'-scenario is, en het beleidsscenario, wat het scenario is van het Mercosur-akkoord. Door deze twee scenario's te vergelijken, meten we de geschatte economische effecten van het Mercosurakkoord tussen 2020 en 2035.

Om het akkoord naar het model te vertalen, vertrouwen we op het door de Europese Commissie en Mercosur overeengekomen markttoegangsschema. Dit schema is op 29 oktober 2019 in vertrouwelijkheid bekendgemaakt aan de EU-lidstaten van het Comité handelspolitiek. In het schema zijn de wijzigingen opgenomen van de bestaande handelsbeschermende maatregelen op de 8-cijferige tarieflijn. Op 8-cijferig niveau blijven de tarieven ongewijzigd, worden ze in gedeelten verlaagd of worden ze volledig afgeschaft. In andere gevallen worden tariefcontingenten geïmplementeerd of aangepast. De exportbelastingmaatregelen voor Mercosur zijn ook opgenomen in de 8-cijferige tarieflijn. We gebruiken gegevens over de handelswaarde om deze maatregelen te aggregeren om de tarief- en exportbelastingseffecten op het geaggregeerde sectorniveau in te schatten.

\section{Tekstvak 1. Tariefverlagingen volgens het akkoord in een notendop}

Volgens het principeakkoord van de Commissie waarin het akkoord wordt samengevat (EC, 2020), zal Mercosur $91 \%$ van zijn import uit de EU volledig liberaliseren gedurende een overgangsperiode van maximaal 10 jaar voor de meeste producten en maximaal 15 jaar voor enkele van de meest gevoelige producten binnen Mercosur. De EU zal 92\% van haar import uit Mercosur liberaliseren gedurende de overgangsperiode van 10 jaar. Mercosur $91 \%$ en de EU $95 \%$ van de tarieflijnen in hun respectieve schema's volledig liberaliseren.

Wat de markttoegang voor industriële goederen betreft, zal de EU binnen een overgangsperiode van maximaal 10 jaar de invoerrechten op alle industriële goederen afschaffen. Mercosur zal de invoerrechten in sectoren als auto's, auto-onderdelen, machines, chemicaliën en geneesmiddelen volledig afschaffen.

Mercosur zal de markttoegang voor landbouwproducten uit de EU verbeteren door de geleidelijke afschaffing van de invoerrechten op $93 \%$ van de tarieflijnen voor de export van landbouwproducten uit de EU naar de regio. Deze lijnen komen overeen met $95 \%$ van de exportwaarde van EU-landbouwproducten naar Mercosur. De EU zal 82\% van de import van landbouwproducten liberaliseren, waarbij de resterende import onderworpen is aan gedeeltelijke liberaliseringsverplichtingen, met inbegrip van tariefcontingenten voor meer gevoelige producten (zie paragraaf 2.2.3 hierboven), waarbij een zeer klein aantal producten in zijn geheel wordt uitgesloten. De heffingen die Mercosur momenteel oplegt voor de export naar de EU van producten zoals sojaproducten (veevoeder voor gebruik in de EU) zullen worden verlaagd of afgeschaft.

Voor onderwerpen zoals herkomstregels, douane en handelsbevordering, SPS, diensten en instellingen (investeringen) en andere aspecten van het akkoord belicht het samenvattende document de belangrijkste kwesties en verwijst het naar de aanvullende documenten die kunnen worden geraadpleegd. De voor het publiek beschikbare documenten op de website van het DG Handel verschaffen echter geen gedetailleerde en concrete aanwijzingen over hoe de handelsbarrières die verband houden met deze niettarifaire maatregelen zullen worden verminderd of opgeheven.

Wij houden binnen het model rekening met tariefcontingenten op geaggregeerd sectorniveau, en dit is daarmee een schatting die is gebaseerd op de tariefcontingenten gespecificeerd op de onderliggende 8-cijferige tarieflijn. We nemen mee: (1) bestaande tariefcontingenten in het basisscenario (vóór het Mercosur-akkoord), (2) de introductie van nieuwe contingenten (als onderdeel van het Mercosurakkoord), (3) wijzigingen in de tarieven binnen het quotum (als onderdeel van het Mercosur-akkoord),

\footnotetext{
${ }^{16}$ Deze veronderstelling is niet bedoeld om enige politieke uitkomst weer te geven, maar om het onderzoek te concentreren op de effecten van Mercosur. Bovendien was de precieze aard van de handels- en economische betrekkingen van het Verenigd Koninkrijk met de EU-27 ten tijde van het opstellen van het rapport niet duidelijk.
} 
en (4) wijzigingen in het totale quotumniveau (als onderdeel van het Mercosur-akkoord). Details over deze tariefcontingenten zijn te vinden in tabel $2.4 \mathrm{t} / \mathrm{m} 2.6$ in het vorige hoofdstuk.

Tot slot houden we rekening met niet-tarifaire maatregelen (NTM's) die van invloed zijn op de handel in goederen en diensten die vanuit de EU de Mercosur-markt binnenkomen. Wij beschouwen de niveaus van de normen en de internationale samenwerking binnen de Europese Economische Ruimte (EER) als grotendeels geharmoniseerd en gebruiken dit dan ook als het basisniveau van NTM's. Vervolgens nemen we in aanmerking hoeveel de handelskosten voor de Mercosur-exporteurs per verhandeld product zouden moeten verminderen om het niveau van de NTM's in de EER te bereiken.

Voor NTM's die de handel in goederen beïnvloeden, gebruiken we schattingen van de handelskosten van de Wereldbank (Kee en Nicita 2017), en voor NTM's die de handel in diensten beïnvloeden, gebruiken we schattingen van de handelskosten voor Mercosur van de Wereldbank (Jafari en Tarr 2015) en voor de EER van de OESO (Benz en Jaax 2020). Vanuit de vermindering van de handelskosten als gevolg van de verminderde handelsbarrières via wijzigingen in de NTM's schatten we de efficiëntiewinst op basis van prijs- en kwantiteitseffecten die we in MAGNET implementeren. In bijlage 2 presenteren we een literatuuronderzoek naar gegevens over NTM's en meer details over hoe deze gegevens worden gebruikt in de simulaties van het CGE-model.

Het uitgangspunt is dat de handelsbarrières voor NTM's in Mercosur in het kader van het akkoord worden verminderd en in de richting van het EER-niveau bewegen, maar dat de niveaus van deze handelsbarrières niet zullen dalen tot EER-niveaus. Daarom is, in navolging van Disdier et al. (2016), de veronderstelling dat er iets gedaan kan worden aan $10 \%$ van de aan NTM gerelateerde handelskosten, wat betekent dat de huidige kloof tussen de relatieve NTM-kosten voor handel in de EER en de NTM-kosten voor handel in Mercosur met $10 \%$ zou worden verkleind. Zo zouden de handelsbarrières (van NTM's) voor de import van verse groenten en fruit uit de EU naar Argentinië met $53 \%$ moeten worden verlaagd om het niveau van de handelsbarrières (van NTM's) op de markt voor verse groenten en fruit binnen de EER te bereiken. Als we ervan uitgaan dat Mercosur-landen verbeteringen zullen aanbrengen om de kloof met het niveau van de handelsbarrières (van NTM's) binnen de EER met $10 \%$ te verkleinen, dan zouden de handelsbarrières (van NTM's) voor verse groenten en fruit die vanuit de EU in Argentinië worden ingevoerd volgens ons met 5,3\% dalen. Dit wordt beschouwd als equivalent van een toename van $5,3 \%$ in de efficiëntie van de import.

Voor de aanname van $10 \%$ bruikbaarheid vinden we, naast de literatuur, verder bewijs uit gesprekken met stakeholders uit de industrie. De meeste vertegenwoordigers van het bedrijfsleven wezen op de langetermijnprocedures voor het verkrijgen van toegang tot de Mercosur-markten. Met name in het geval van landbouw- en voedselproducten waren er grote verschillen in de eisen die aan de voedselveiligheid en de kwaliteit worden gesteld.

Voor de handel in goederen zijn NTM's landspecifiek en bilateraal. Een vermindering van de handelsbarrières (van NTM's) voor goederen volgt dus het bovenstaande voorbeeld van handelsbarrières voor groenten en fruit uit de EU naar Argentinië die met 5,3\% afnemen. Voor NTM's in de handel in diensten wordt er echter van uitgegaan dat als een land de barrières vermindert, dit geldt voor alle handelspartners. Daarom zal een liberalisering van de dienstenmarkt door elk van de Mercosur-leden deze markt zowel binnen Mercosur en als ook voor Europa en andere handelspartners openen.

\subsection{Macro-economische resultaten}

De macro-economische effecten van het handelsakkoord tussen de EU en Mercosur worden in dit hoofdstuk hieronder samengevat wat betreft veranderingen in de bbp-groei, in relatieve zin (percentages, figuur 3.1) en in absolute zin (miljoenen euro's, figuur 3.2). De sectorsamenstelling wordt gepresenteerd voor de economie in Nederland en de rest van de EU-27 (figuur 3.3 en 3.4). Tot slot komt het relatieve belang van handel (import en export als percentage van de productie, hierna aangeduid met de Engelse termen 'trade exposure', 'import exposure', en 'export exposure') aan bod, waarbij inzicht wordt geboden in de bbp-resultaten (figuur 3.5 en 3.6). 


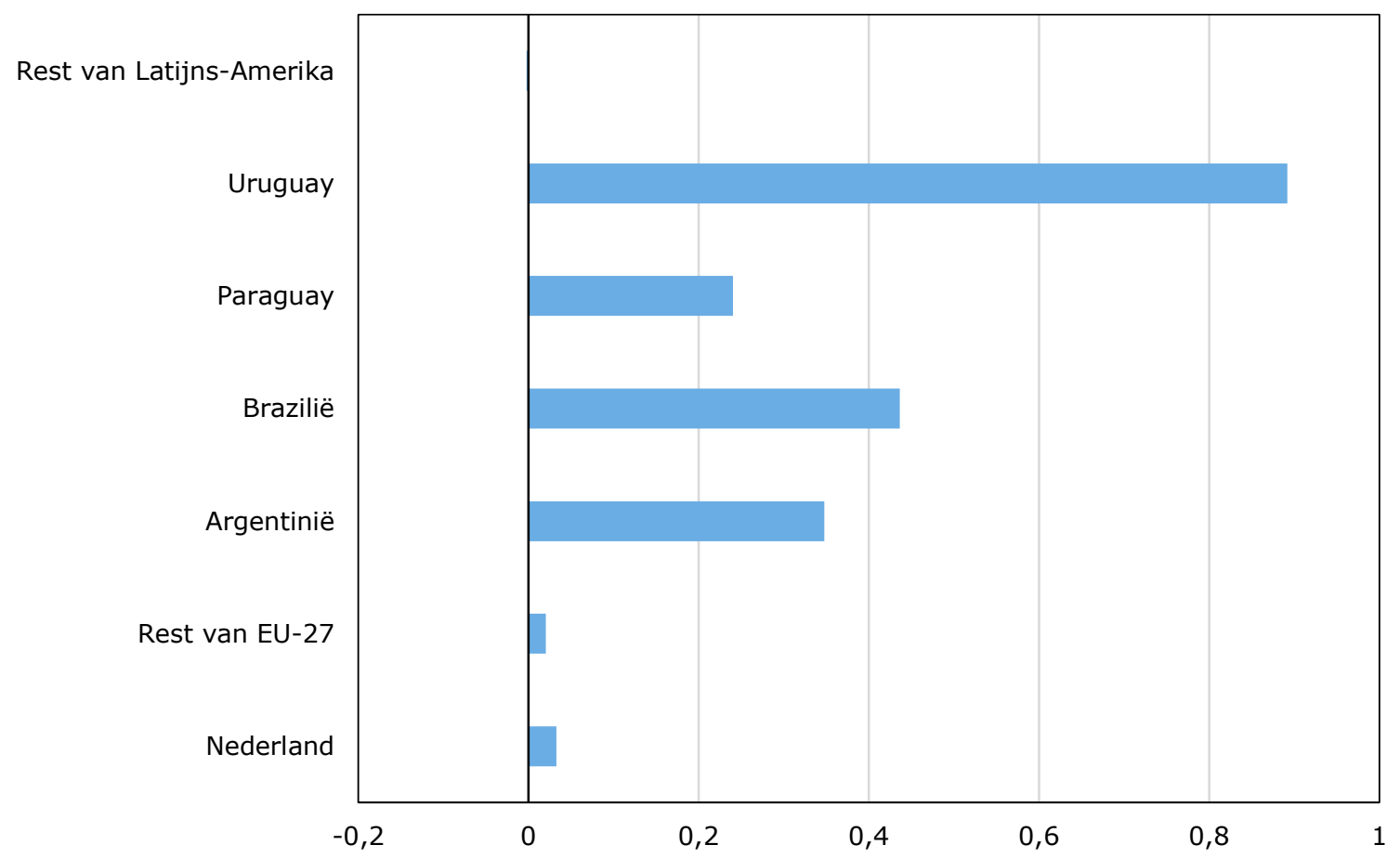

Figuur 3.1 Verschil in bbp-groei onder het Mercosur-akkoord van 2020 tot 2035, \%

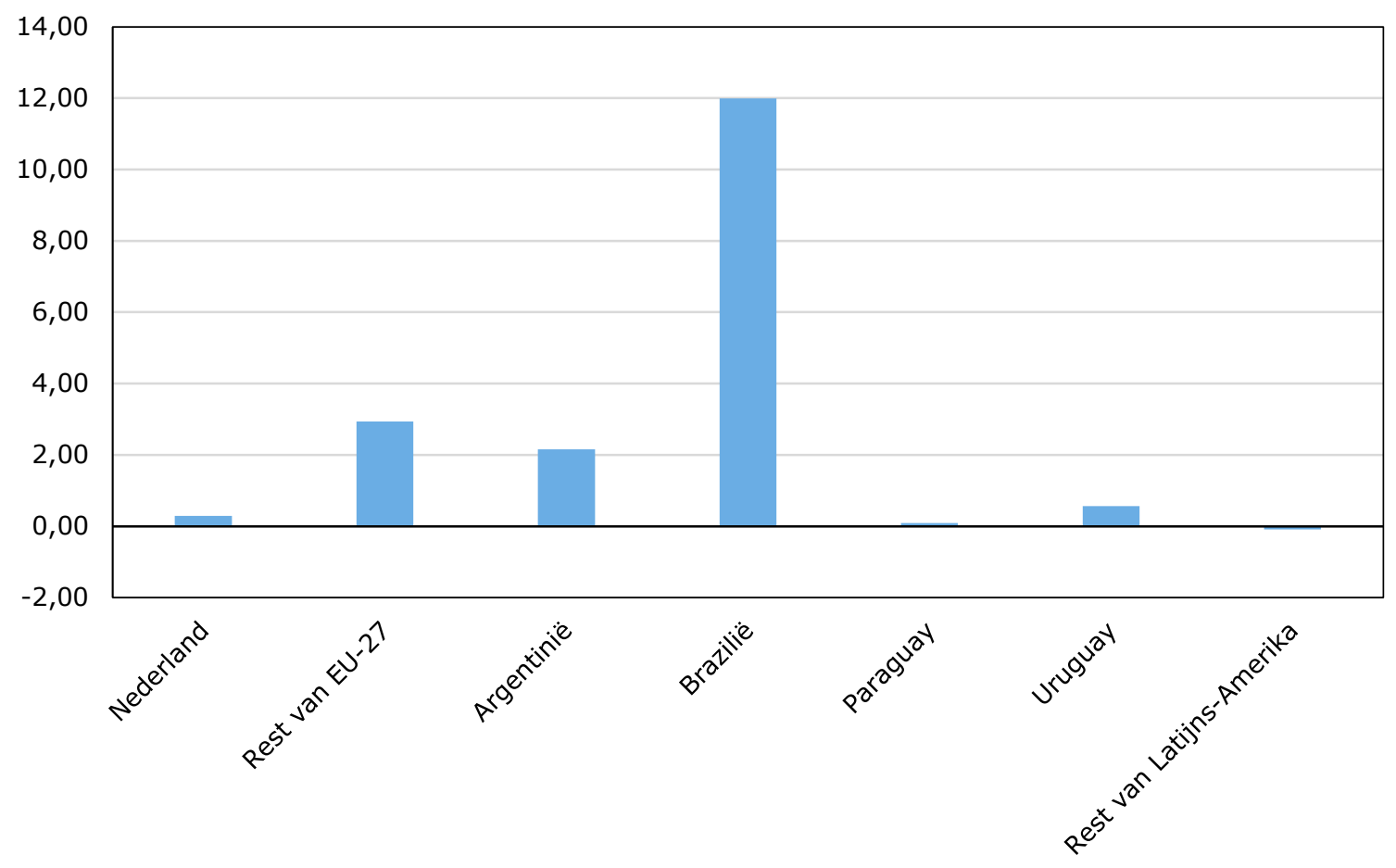

Figuur 3.2 Werkelijke bbp-groei in 2035 in het kader van het Mercosur-akkoord, miljarden $€$

De macro-economische implicaties van het Mercosur-akkoord zullen naar schatting gering zijn, met beperkte effecten op de bbp-groei. In figuur 3.1 wordt het verschil in bbp-groei gepresenteerd voor de periode 2020 tot 2035, wat de periode is waarin het Mercosur-akkoord naar veronderstelling wordt geïmplementeerd. De verwachte bbp-groei (denk aan de veronderstelling van vóór corona) is onder het Mercosur-akkoord enigszins hoger voor Nederland (0,03\%) en de rest van de EU-27 (0,02\%). Maar het zullen de vier Mercosur-landen zijn die naar verwachting als gevolg van het akkoord de grootste winst voor de gehele economie boeken, hoewel de bbp-groei nog steeds minder dan $1 \%$ zal bedragen. 
Figuur 3.2 laat de extra winst in bbp in miljard euro zien in 2035 als gevolg van het Mercosur-akkoord. Hier zien we dat Nederland in 2035 naar verwachting een winst van 287 miljoen euro zal behalen en de rest van de EU-27 2,93 miljard euro. De grootste winst wordt verwacht voor Brazilië met een geschatte winst van 12 miljard euro in 2035.

De bbp-resultaten hebben te maken met de samenstelling van de sectoroutput. Het Mercosur-akkoord bestaat uit een beleid op product- en sectorniveau dat over een periode van 15 jaar moet worden geïmplementeerd. Het belang van de effecten van dit beleid op sectorniveau voor de hele economie hangt dus af van het relatieve belang van een bepaalde sector of van het aandeel daarvan in de productie van de hele economie.

Figuur 3.3 laat de sectorsamenstelling van de gehele Nederlandse economie zien. We zien dat de dienstensectoren voor de economie veruit de belangrijkste zijn qua samenstelling, want ze omvatten $67,5 \%$ van de output van de hele Nederlandse economie. Dit betekent dat de belangrijkste sector voor de economie de geaggregeerde dienstensector is, gevolgd door de productie- en de agrifoodsectoren, die respectievelijk $25 \%$ en $7,5 \%$ van de totale output van de economie omvatten. In figuur 3.4 is een vergelijkbare sectorsamenstelling van de economie in de rest van de EU-27 te zien, waarbij de dienstensector $68 \%$ van de economie omvat, gevolgd door de productie- en de agrifoodsectoren, die elk $26 \%$ en $6 \%$ van de economie omvatten. ${ }^{17}$

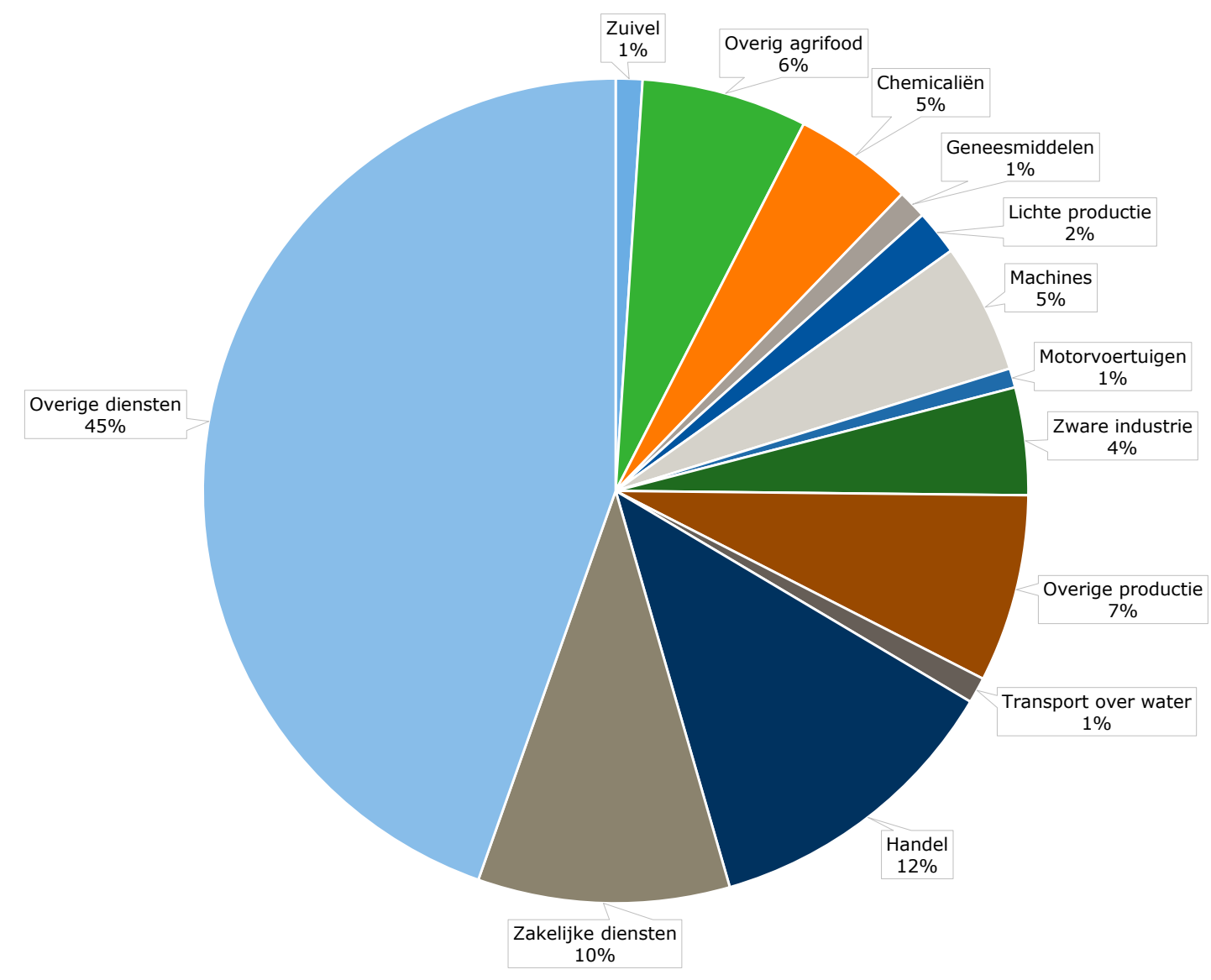

Figuur 3.3 Sectorsamenstelling van output van de hele Nederlandse economie

\footnotetext{
${ }^{17}$ De gegevens voor figuur 3.3 en 3.4 zijn afkomstig uit de MAGNET-database.
} 


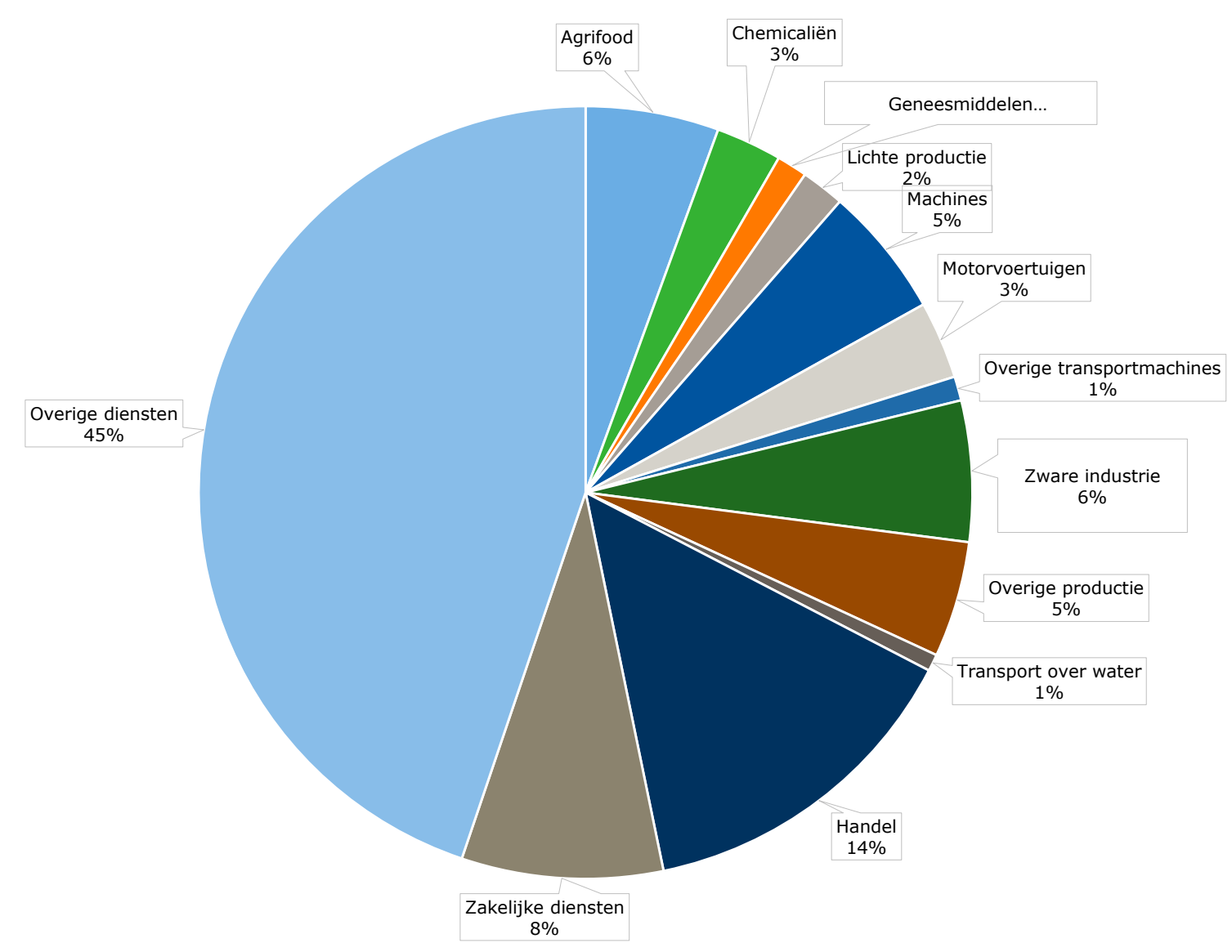

Figuur 3.4 Sectorsamenstelling van de output van de hele economie voor de rest van de EU-27

In het Mercosur-akkoord worden beleidswijzigingen voorzien voor de tarieven (van invloed op industrie- en landbouwproducten), tariefcontingenten (van invloed op agrifoodproducten), en NTM's (van invloed op alle producten). Daarom heeft het merendeel van de beleidswijzigingen (tarieven en tariefcontingenten) slechts invloed op 32,5\% van de Nederlandse economie wat betreft aandeel in de output. Verder hangt het precieze effect op deze sectoren af van de Mercosur trade exposure van de sectoren en dus van de mogelijkheid dat de beleidswijzigingen op productniveau zich vertalen naar effecten op sectorniveau in Nederland.

In figuur 3.5 en 3.6 is de trade exposure te zien van een aantal economische sectoren van Nederland en de rest van de EU-27 ten opzichte van Mercosur, gemeten aan de hand van de verhouding tussen de waarde van de handelsstroom en de totale waarde van de sectoroutput. Over het algemeen is er bij de agrifood--sectoren sprake van een hoger niveau van import exposure, en bij de producerende sector en de dienstensector een hoger niveau van export exposure. ${ }^{18}$ Hoewel de algemene niveaus relatief laag zijn, zijn voor Nederland de sectoren die relatief het meest betrokken zijn bij de handel met Mercosur onder meer rund- en pluimveevlees (import exposure), en geneesmiddelen en overige transportmiddelen (export exposure). Vergeleken met de rest van de EU-27 heeft Nederland te maken een relatief veel trade exposure in deze kernsectoren, hoewel voor andere sectoren het relatieve belang van handel met Mercosur minder is (bijv. chemicaliën en transport over water).

\footnotetext{
${ }^{18}$ Zoals eerder vermeld, zijn de weergegeven sectoren geaggregeerde sectoren in een mondiaal model waardoor een zekere mate van detail wordt geabstraheerd. Een voorbeeld: bij de sector groenten en fruit bestaat de import grotendeels uit citrusvruchten, en die worden niet in Nederland geproduceerd.
} 


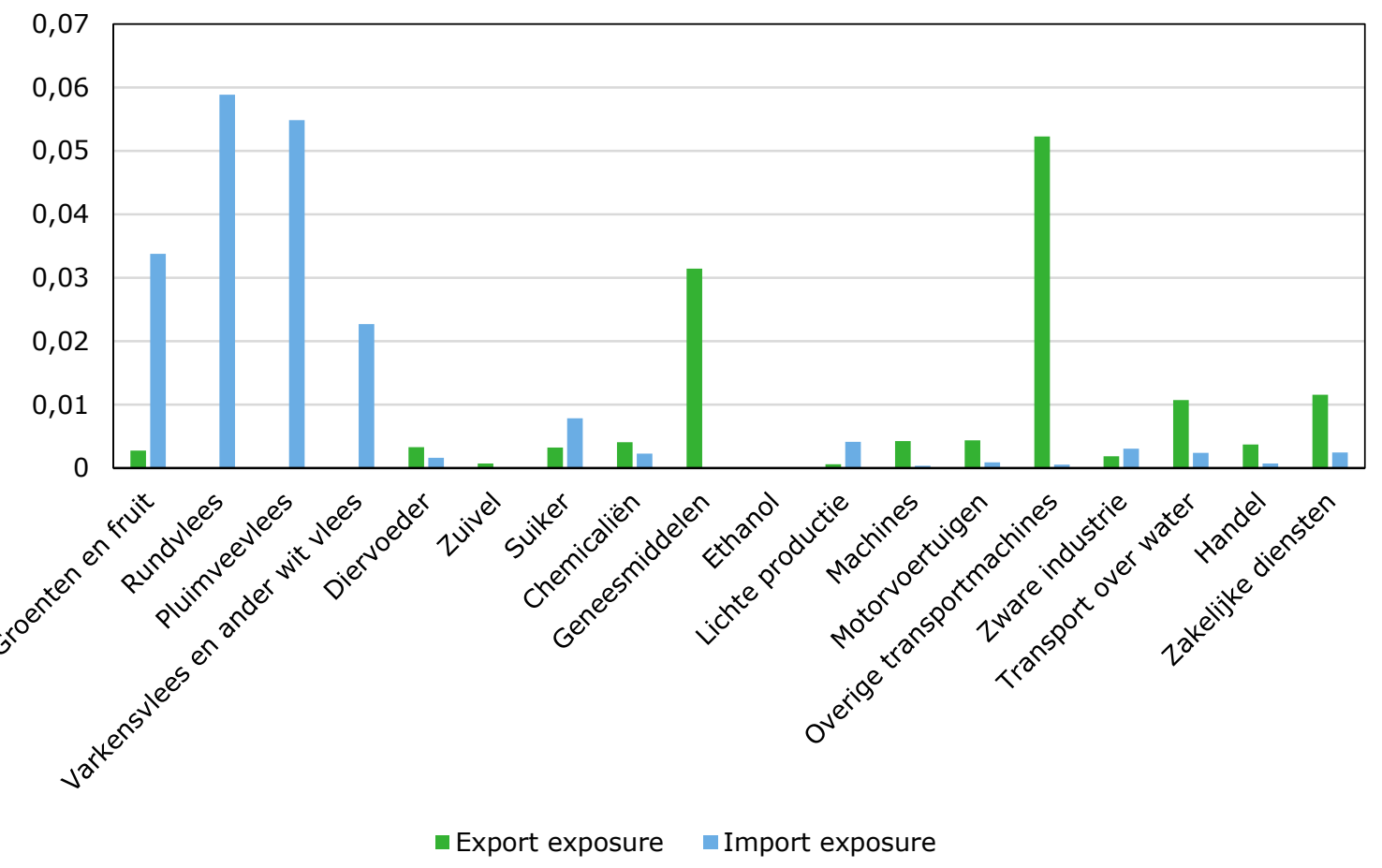

Figuur 3.5 Belang voor Nederland van de handel aan Mercosur (verhouding tussen de waarde van de handelsstroom en de totale waarde van de sectoroutput)

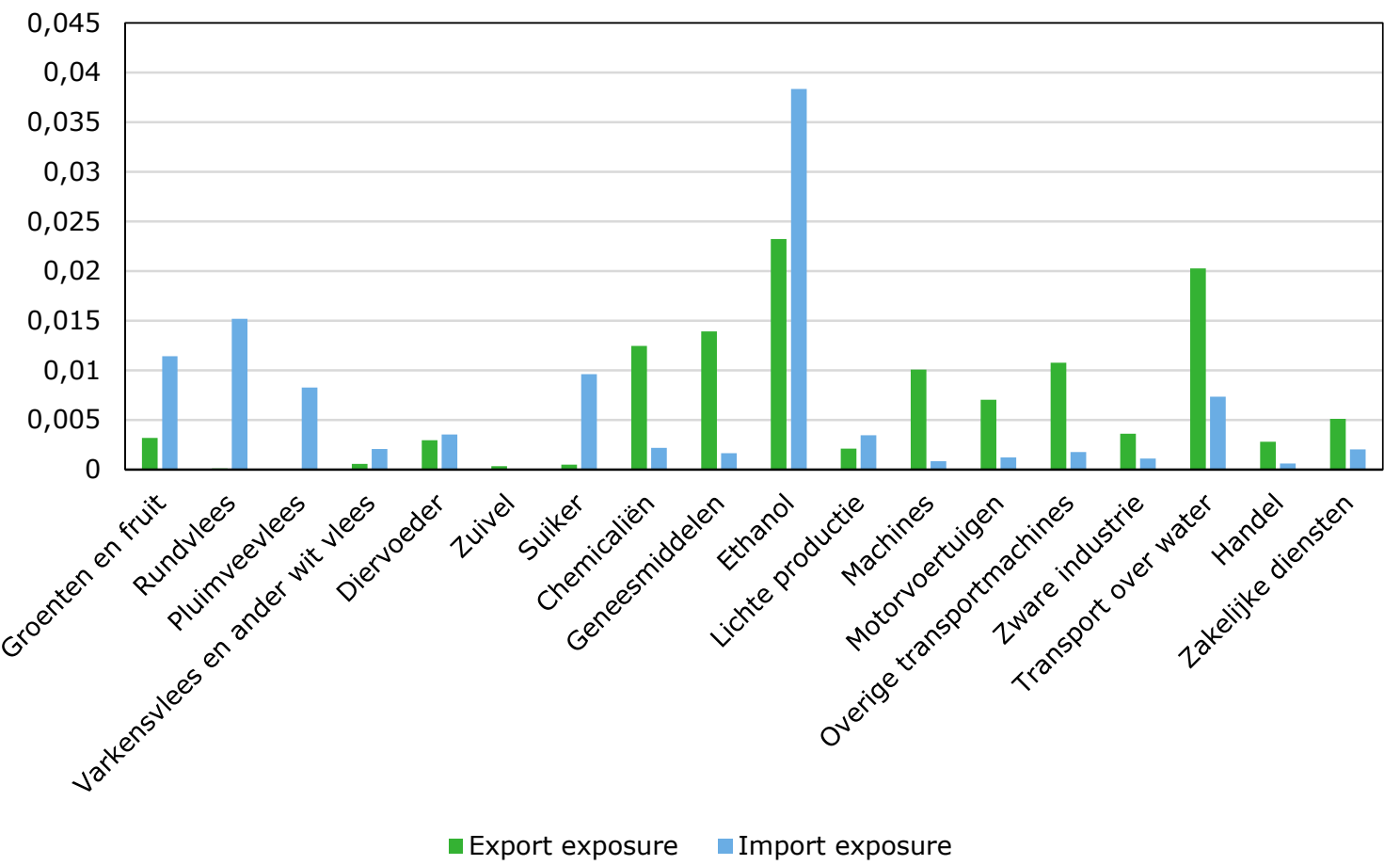

Figuur 3.6 Belang voor de rest van de EU-27 van de handel aan Mercosur (verhouding tussen de waarde van de handelsstroom en de totale waarde van de sectoroutput) 


\subsection{Sectorspecifieke resultaten}

Figuur 3.7 en 3.8 laten de productieresultaten op sectorniveau zien van een selectie van sectoren voor respectievelijk Nederland en de rest van de EU-27. In het algemeen zijn de sectoren met een hogere import exposure de daarmee verbonden primaire sector (bijv. rundvee, dat met de rundvleessector is verbonden) de sectoren die negatieve effecten ondervinden van de concurrentie van de import. Aan de andere kant zijn de sectoren met de hoogste export exposure de sectoren die positief worden beïnvloed door de uitbreiding van de Mercosur-markt via de groei van de export. ${ }^{19}$ Natuurlijk spelen ook andere factoren een rol, zoals de relatieve groei van de import ten opzichte van de export (figuur $3.11 \mathrm{t} / \mathrm{m}$ figuur 3.18) voor overeenkomstige producten, het soort handelsmaatregel dat wordt ingevoerd (bijv. tariefcontingenten), evenals veranderingen door indirecte effecten.

In Nederland worden de hoogste productiewinsten geschat voor de sectoren overige transportmachines $(1,42 \%)$, geneesmiddelen $(1,16 \%)$ en pluimveevlees $(0,93 \%)$ (figuur 3.7$)$. De productie van pluimveevlees neemt toe naarmate Nederland zijn productie verhoogt om aan de Europese vraag te voldoen. De sector overige transportmachines en de sector geneesmiddelen groeien dankzij de toenemende groei van de export (zie figuur 3.11 en 3.12).

In de rest van de EU-27 vindt de grootste productie-uitbreiding plaats in de sector machines $(1,52 \%)$. Er vindt slechts een lichte $(<0,5 \%)$ toename plaats in de sectoren motorvoertuigen $(0,43 \%)$, zware industrie $(0,26 \%)$ en chemicaliën $(0,13 \%)$ (figuur 3.8$)$. De toename voor de sectoren machines, motorvoertuigen en zware industrie wordt veroorzaakt door toename van de exportgroei naar Mercosur (figuur 3.15 en 3.16).

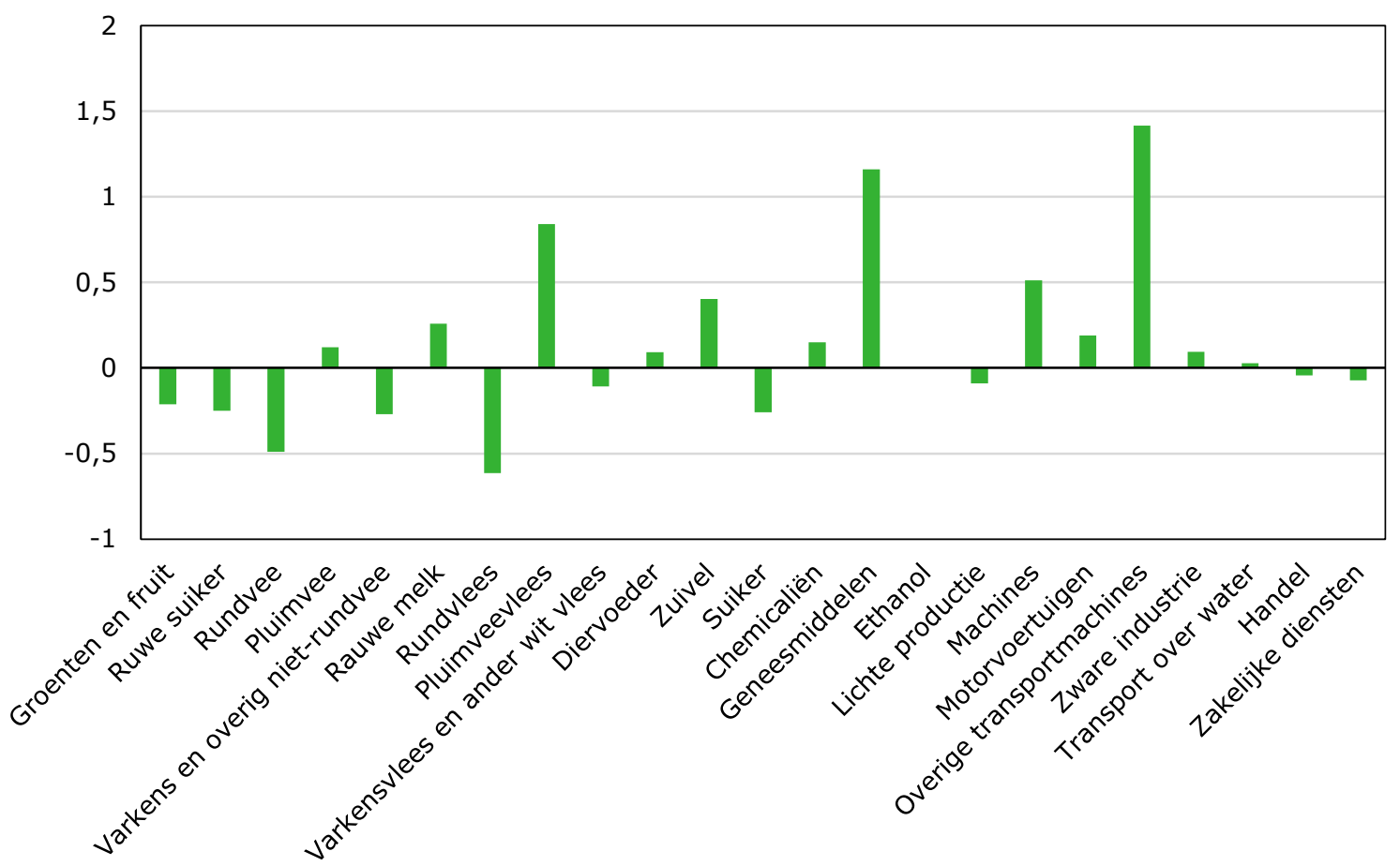

Figuur 3.7 Verschil onder het Mercosur-akkoord in de Nederlandse productiegroei in 2035, \% $\Delta$

\footnotetext{
${ }^{19}$ Vanwege de aggregatie van modellen kan de blootstelling aan de handel de productie sterker lijken te beïnvloeden dan het bewijs op microniveau suggereert. Voortbordurend op het voorbeeld van de sector groenten en fruit: als de import op microniveau grotendeels bestaat uit citrusvruchten en andere producten die niet in Nederland worden geproduceerd, kan de productie in de sector groenten en fruit in Nederland afwijken van wat de modelresultaten suggereren. Daarom kunnen de modelresultaten worden beschouwd als potentiële effecten voor de hele sector. Zo zouden de modelresultaten bijvoorbeeld kunnen wijzen op een situatie waarin de consument vanwege prijseffecten overstapt van binnenlandse groenten en fruit naar geïmporteerde groenten en fruit uit Mercosur (ook al zijn het geen identieke producten).
} 


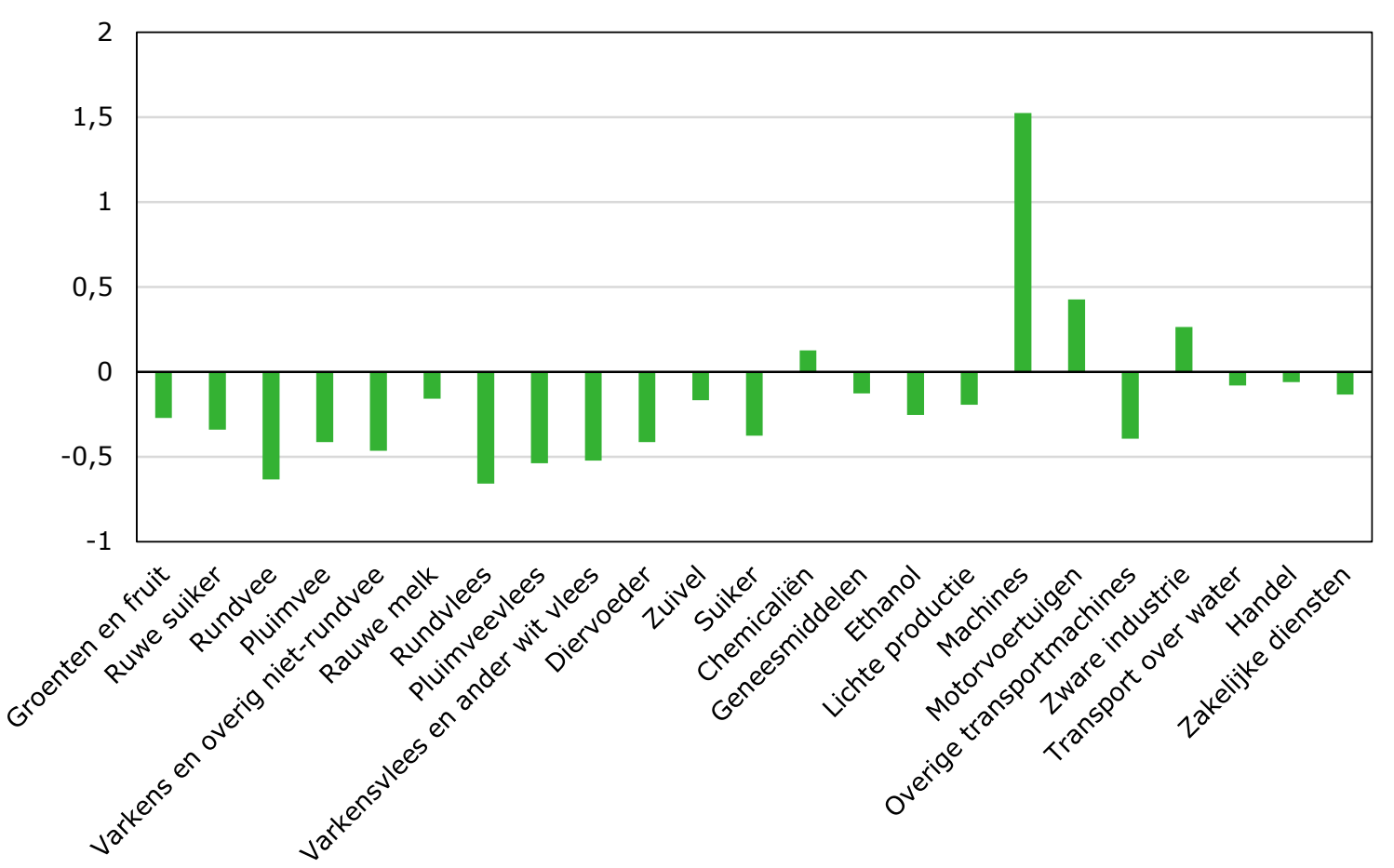

Figuur 3.8 Verschil onder het Mercosur-akkoord in de productiegroei van de rest van de EU-27 in 2035, \% $\Delta$

Figuur 3.9 en 3.10 tonen de geschatte arbeidsmarktresultaten voor respectievelijk Nederland en de rest van de EU-27 in de vorm van de geschatte veranderingen in de werkelijke loonsom per sector in 2035 als gevolg van het akkoord. De loonsom is de waarde van arbeid bestaande uit alle lonen van alle werknemers en is dus de arbeidscomponent van de toegevoegde waarde. ${ }^{20} \mathrm{Bij}$ een constante arbeidsproductiviteit volgen de effecten van de loonsom de effecten van de productie, waarbij de werkelijke loonsom naar verwachting zal afnemen door krimpende sectoren en toenemen door groeiende sectoren in antwoord op de afnemende resp. toenemende vraag naar output. Voor Nederland wordt een groei van de werkelijke loonsom verwacht voor de sectoren overige transportmiddelen $(1,43 \%)$, geneesmiddelen $(1,18 \%)$ en pluimveevlees $(0,85 \%)$ (figuur 3.9$)$. Voor de rest van de EU-27 wordt de grootste groei verwacht in de sector machines, waarbij de werkelijke loonsom naar schatting met 1,52\% zal stijgen (figuur 3.10).

\footnotetext{
${ }^{20}$ In theoretische termen bestaat de loonsom uit twee componenten, namelijk (1) loon en (2)werknemers. Omdat het een mondiaal model is, zijn er in het MAGNET-model geen individuele werknemers; alleen de loonsom is expliciet in het model opgenomen. Daarom tellen we de effecten op de loonsom mee.
} 


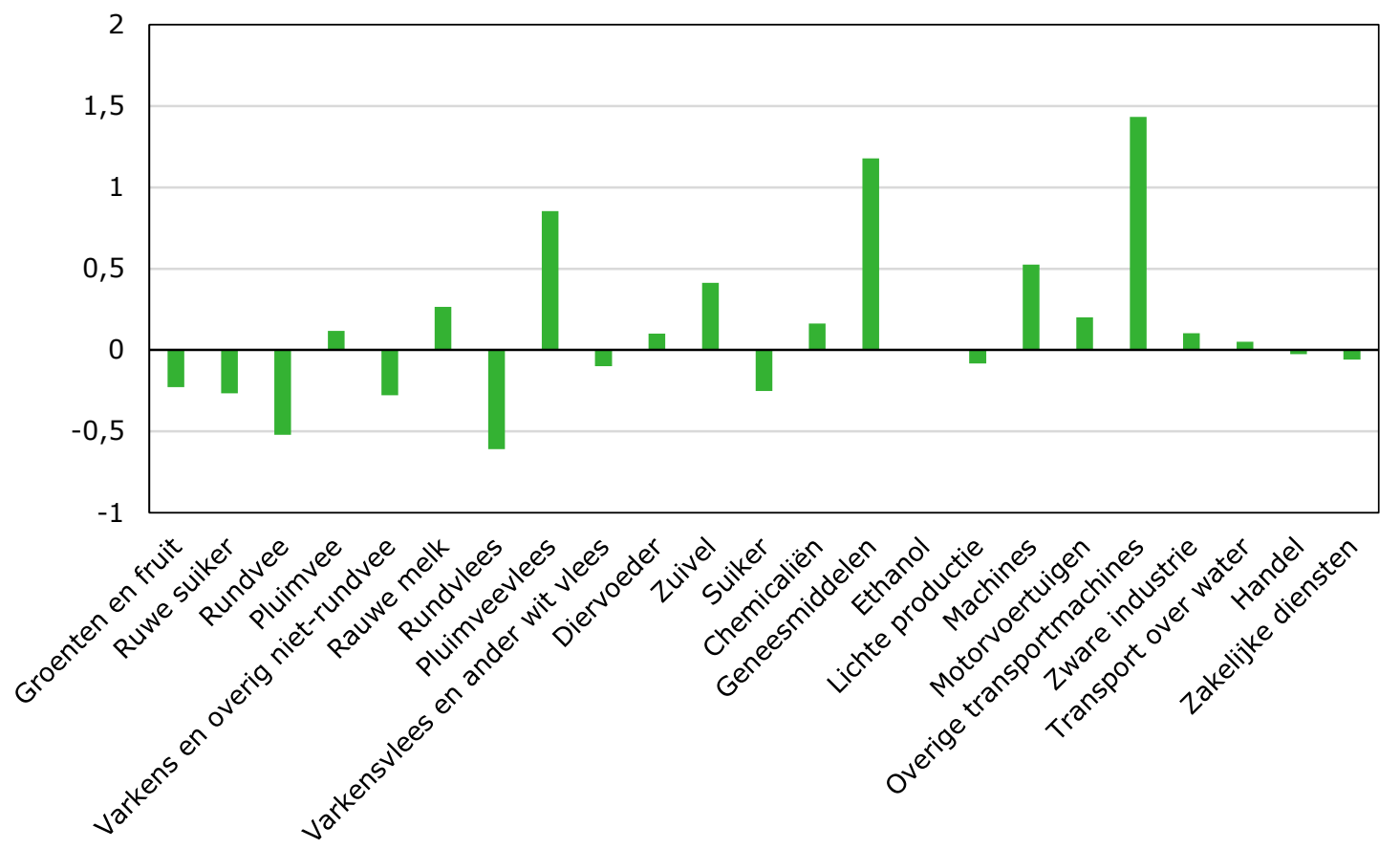

Figuur 3.9 Effecten op de werkelijke loonsom per sector in Nederland in 2035 onder het Mercosurakkoord, \%

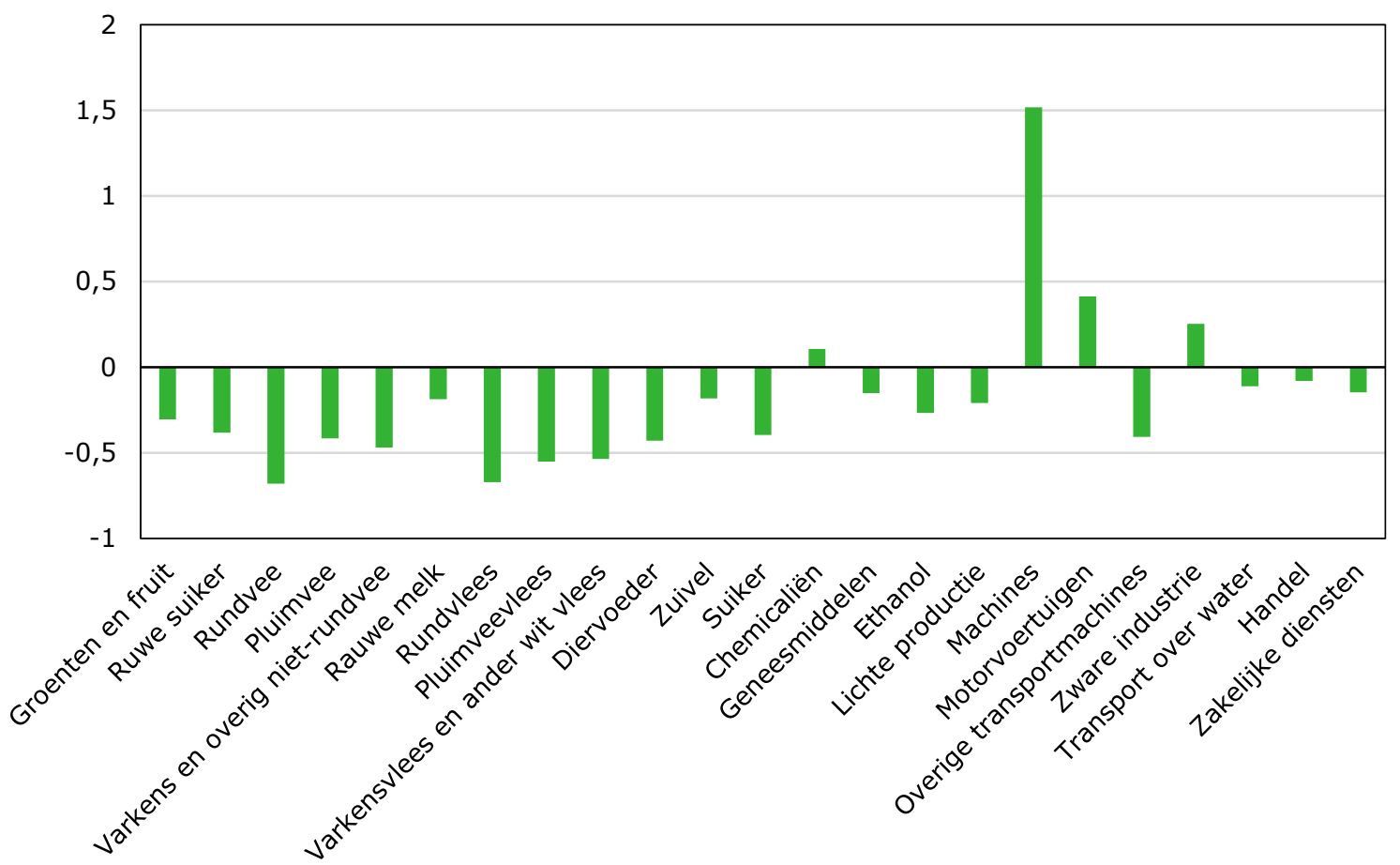

Figuur 3.10 Effecten van de werkelijke loonsom per sector in de rest van de EU-27 in 2035 onder het Mercosur-akkoord, \% $\Delta$

In figuur $3.11 \mathrm{t} / \mathrm{m}$ figuur 3.14 zijn de geschatte export- en importeffecten te zien op de Nederlandse handel met de vier Mercosur-landen, weergegeven in relatieve zin (procentuele verandering) en absolute zin (miljoenen euro's). De groei van de export is voor Nederlandse exporteurs het directe gevolg van de liberalisering van de Mercosur-markt, en de groei van de import naar Nederland is het directe gevolg van de liberalisering van de Nederlandse markt voor de Mercosur-exporteurs. Voor sectoren met een hoge export exposure wordt een rechtstreekse groei van de export verwacht 
(figuur 3.5). Bij indirecte effecten van het akkoord tussen de EU en Mercosur op Nederland gaat het om effecten via de Nederlandse handelsrelaties met de rest van de EU-27. ${ }^{21}$

Over het geheel genomen zijn de hoogste niveaus van groei van de export in figuur 3.12 voor machines (690 miljoen euro), gevolgd door geneesmiddelen (352 miljoen euro). In figuur 3.14 zijn de hoogste niveaus van groei van de import voor groenten en fruit (143 miljoen euro), chemicaliën). (142 miljoen euro) en zware industrie (93 miljoen euro). De producten in productie en diensten vertonen zowel een groei van de export als van de import, maar bij de agrifood-producten zijn er slechts significante groeiniveaus (gemeten in miljoenen euro's) in de import. Dit komt omdat er momenteel weinig export van agrifood naar Mercosur vanuit Nederland plaatsvindt, terwijl er relatief meer import van agrifood vanuit Mercosur naar Nederland is.

In figuur 3.15 worden de netto handelseffecten weergegeven als de verandering in de sectorhandelsbalans voor de bilaterale handel tussen Nederland en Mercosur. Dit is de verwachte exportgroei onder de overeenkomst (figuur 3.12) minus de verwachte importgroei onder van de overeenkomst (figuur 3.14). De sectoren machines en geneesmiddelen vertonen de sterkste groei in bilaterale handelsbalans, respectievelijk 672 miljoen en 351 miljoen euro. Als we kijken naar de sectoren in hun geheel, dan is de groei van de export groter dan de groei van de import en is er een netto positieve groei van de handelsbalans in alle sectoren.

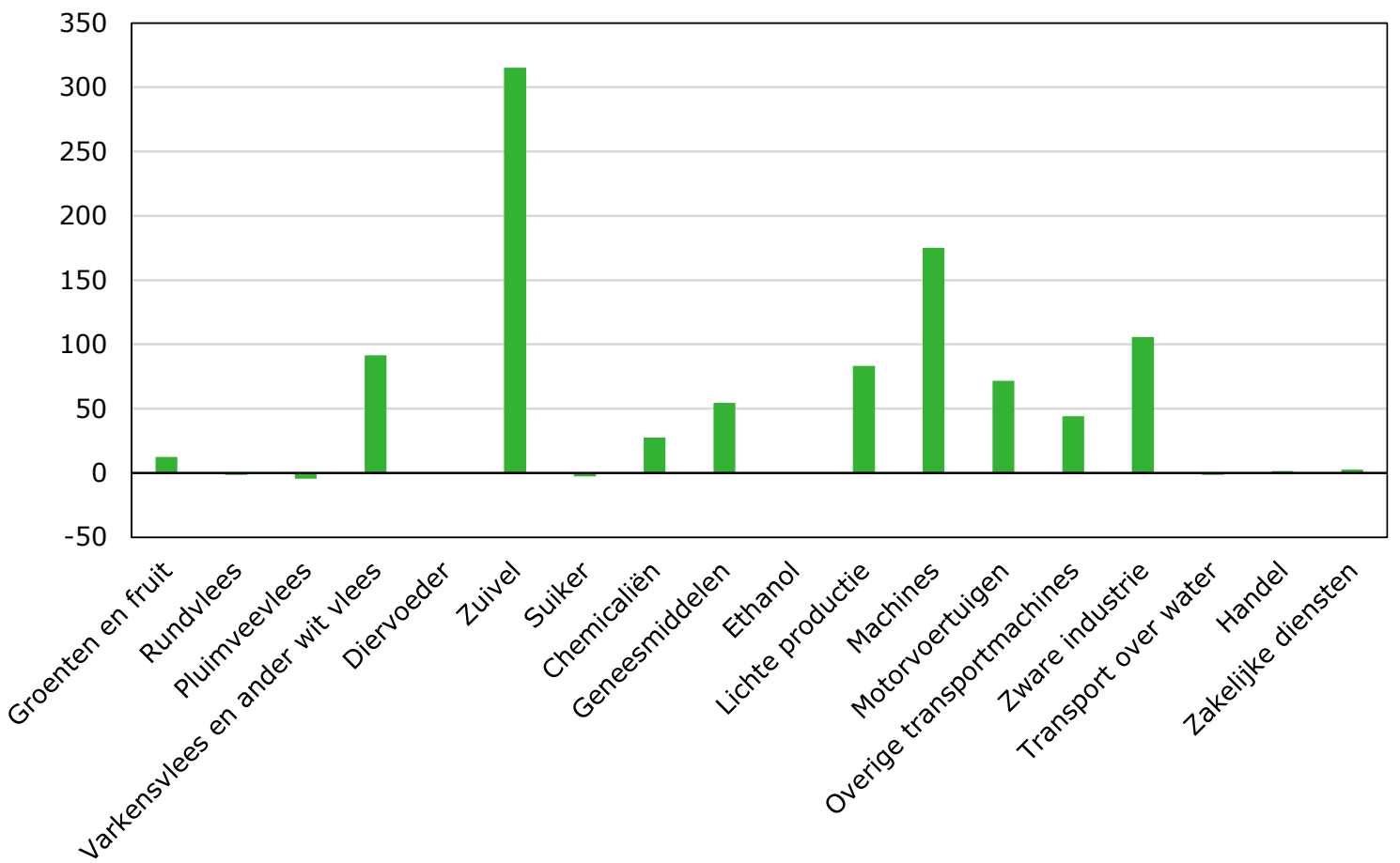

Figuur 3.11 Verschil in Nederlandse groei van de export naar de vier Mercosur-landen in de periode 2020-2035 onder het Mercosur-akkoord, \%

\footnotetext{
${ }^{21}$ Met name de rest van de EU-27 wordt rechtstreeks beïnvloed door het akkoord tussen de EU en Mercosur, en de rest van de EU-27 is de hoofdhandelspartner van Nederland. Daarom past de handel (export en import) tussen Nederland en de rest van de EU-27 zich aan naarmate handels-, vraag- en aanbodpatronen voor de rest van de EU-27 veranderen als rechtstreeks gevolg van het akkoord.
} 


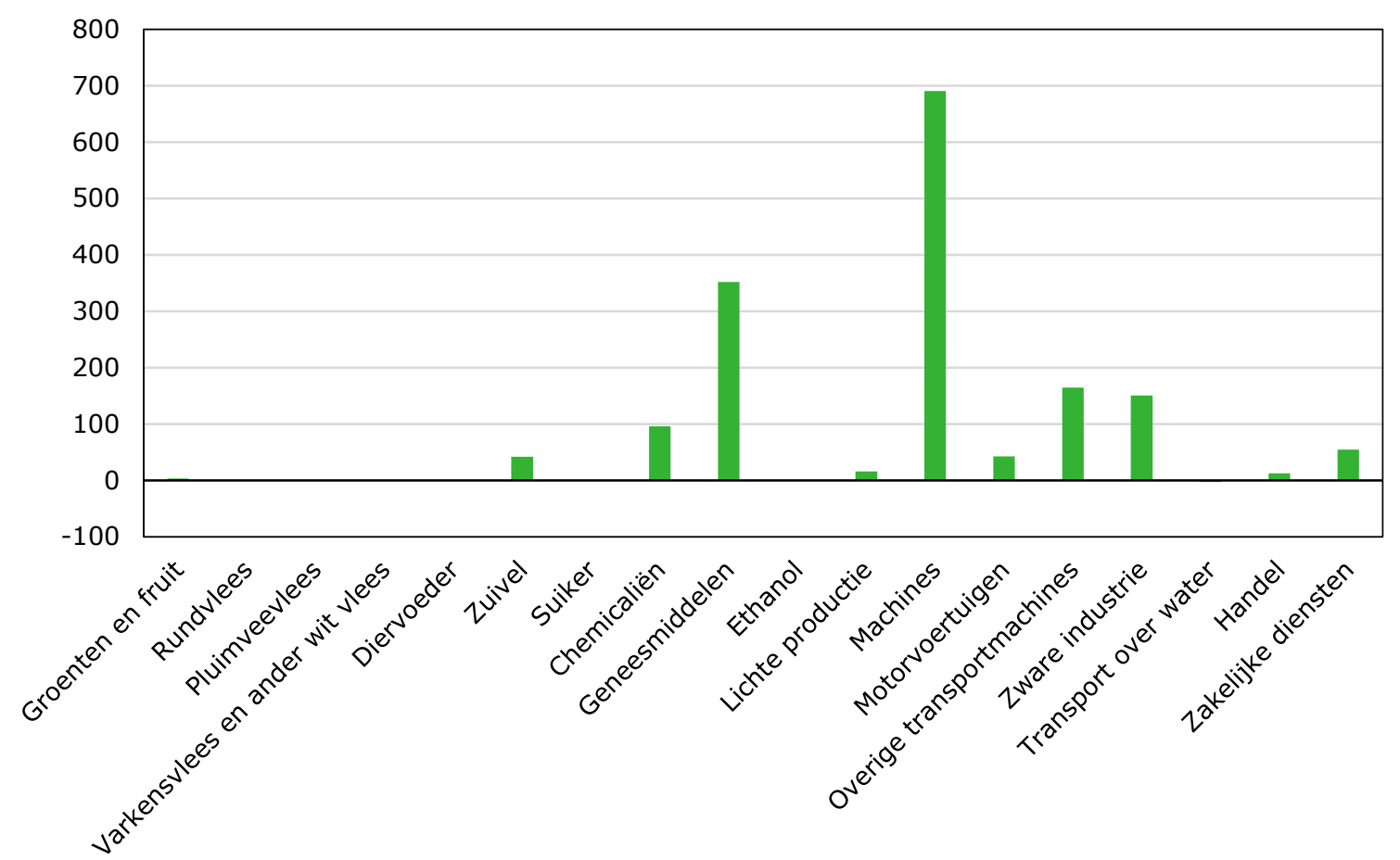

Figuur 3.12 Groei van de Nederlandse export naar de vier Mercosur-landen in 2035 onder het Mercosur-akkoord, miljoenen $€$

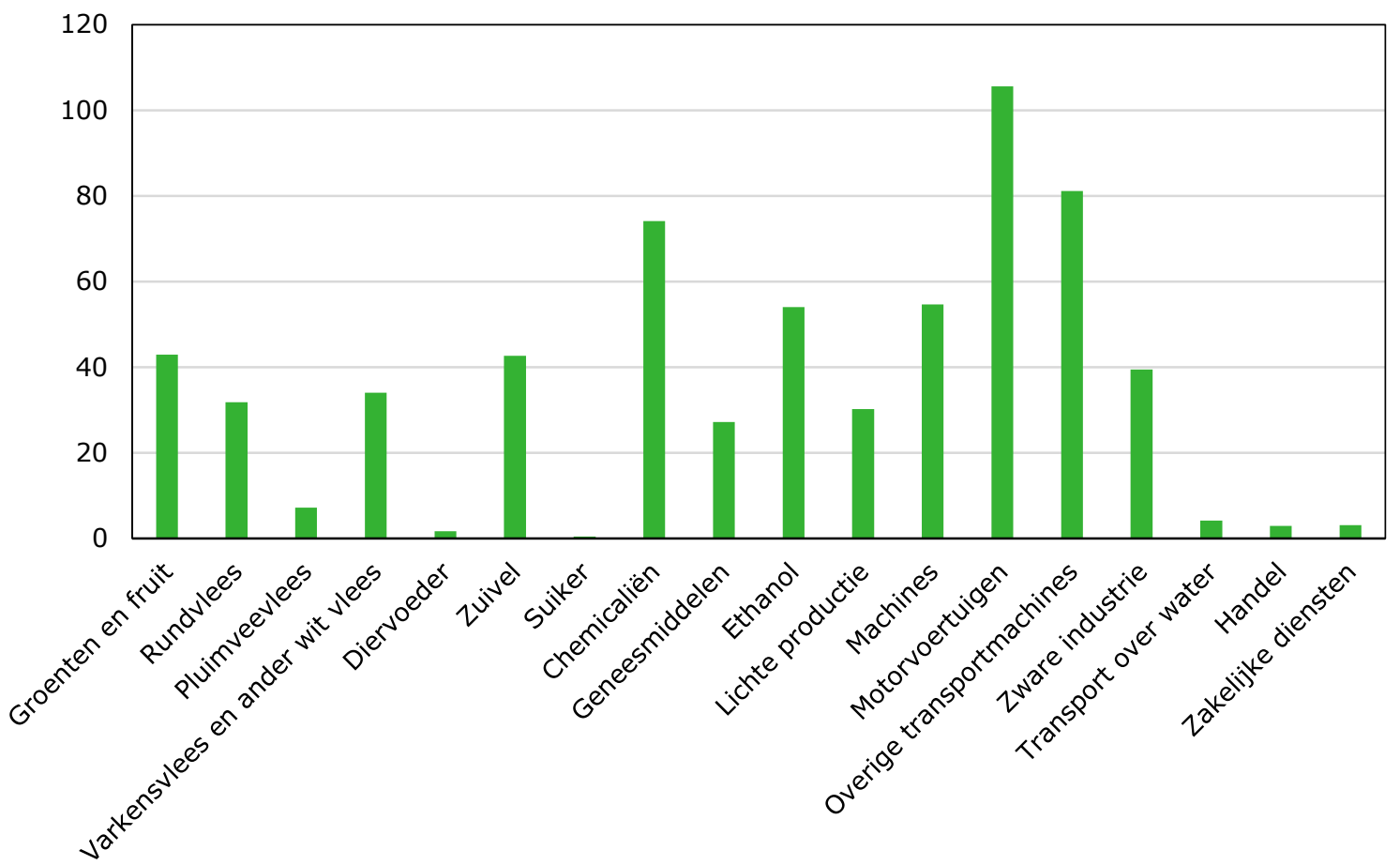

Figuur 3.13 Verschil in groei van de Nederlandse import van de vier Mercosur-landen in de periode 2020-2035 onder het Mercosur-akkoord, \% 


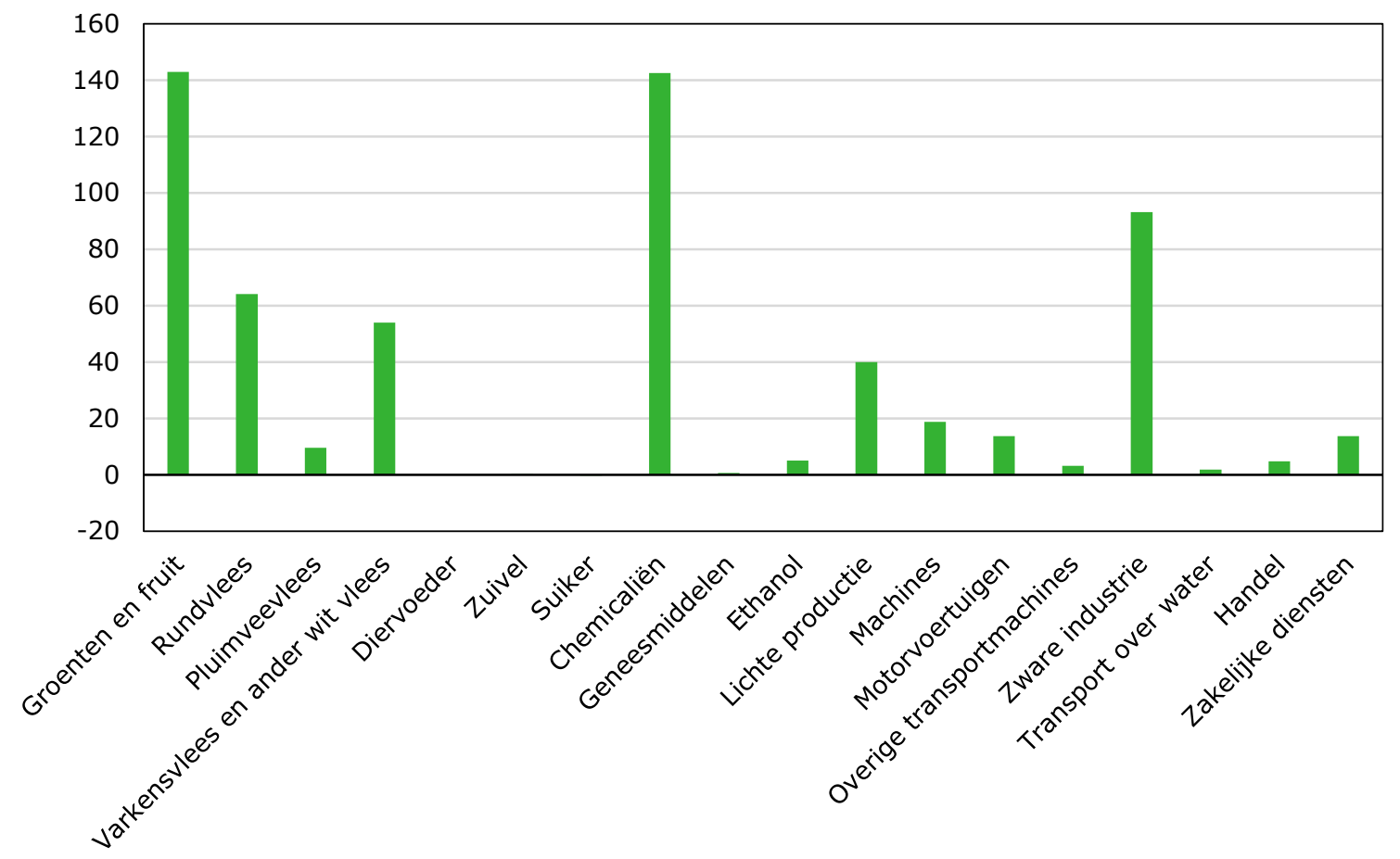

Figuur 3.14 Groei van de Nederlandse import uit de vier Mercosur-landen in 2035 onder het Mercosur-akkoord, miljoenen $€$

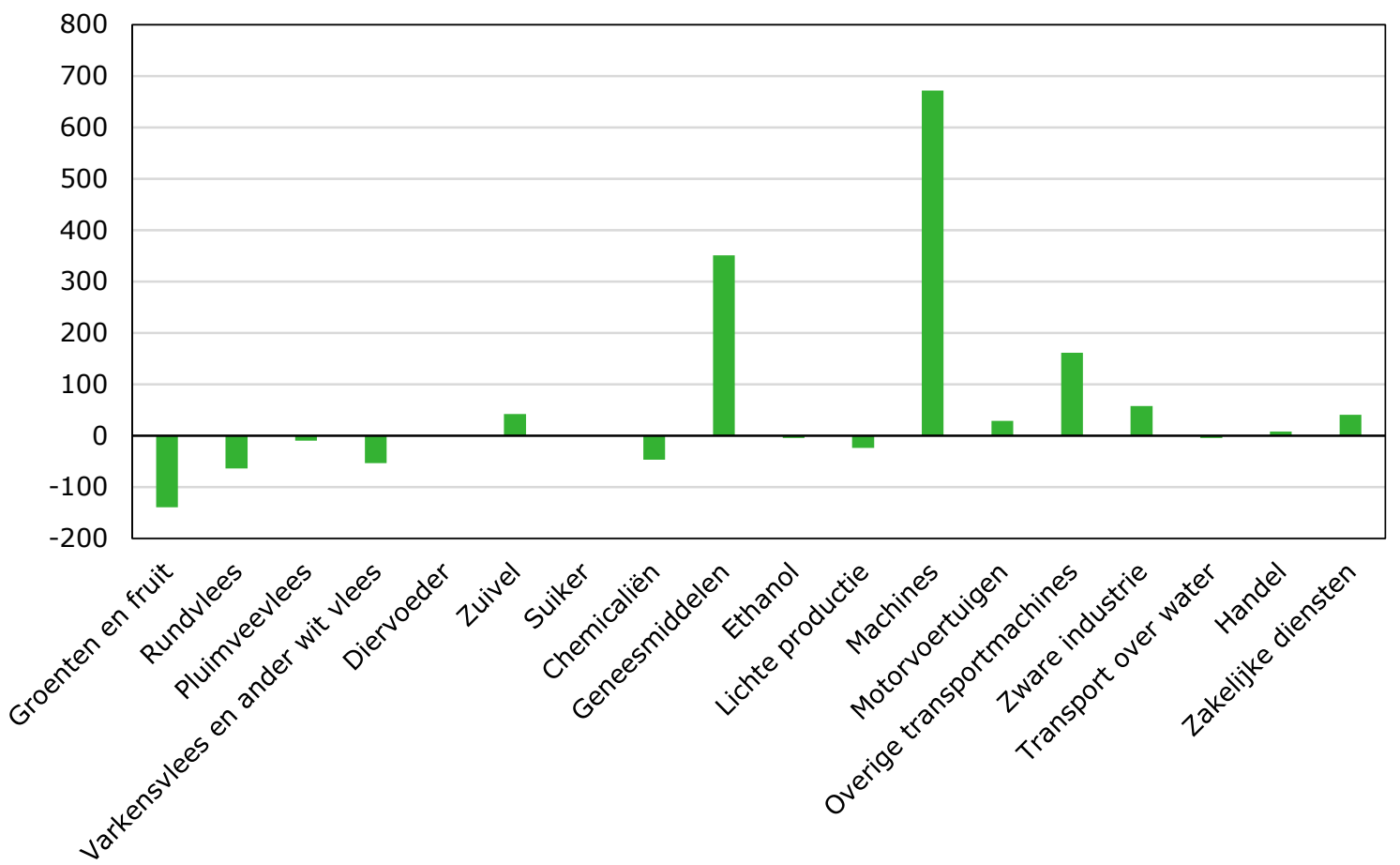

Figuur 3.15 Verandering van de handelsbalans tussen Nederland en Mercosur in 2035 onder het Mercosur-akkoord, miljoenen $€$

Op vergelijkbare wijze zijn in figuur $3.16 \mathrm{t} / \mathrm{m}$ figuur 3.19 de geschatte effecten te zien van de export en import voor de handel van de rest van de EU-27 met de vier Mercosur-landen in relatieve zin (procentuele verandering) en absolute zin (miljoenen euro's). In de rest van de EU-27 is een soortgelijk beeld te zien, waarbij de liberalisering van de Mercosur-markt de export van de rest van de EU-27 naar Mercosur stimuleert (groei van de export), en de liberalisering van de markt van de rest van de EU-27 de export van Mercosur naar de rest van de EU-27 stimuleert (groei van de import). De 
productie- en de dienstensectoren vertonen ook hier zowel een groei van zowel export als import, terwijl producten uit de agrifood-sector slechts een relatief significante importgroei laten zien (gemeten in miljoenen euro's).

In de rest van de EU-27 wordt de grootste exportgroei behaald in de sector machines $(27,73$ miljard euro), gevolgd door de sectoren motorvoertuigen (8,33 miljard euro) en zware industrie (7,71 miljard euro) (figuur 3.17). De grootste toename van de importgroei in de rest van de EU-27 betreft de sectoren chemicaliën (1,15 miljard euro) en motorvoertuigen (1,12 miljard euro's) (figuur 3.19). De importgroei deze twee sectoren is een weerspiegeling van de sectoruitbreiding. Dit zijn inputs die bijdragen aan de uitbreiding van de productie, aangezien verwacht wordt dat deze sectoren over het geheel genomen zullen groeien (figuur 3.8).

De verandering in de handelsbalans per sector voor de handel tussen de rest van de EU-27 en Mercosur laat de verwachte netto handelswinst als gevolg van het akkoord zien. De groei van de handelsbalans is het grootst voor de sector machines, met 26,9 miljard euro, gevolgd door een groei voor de sector motorvoertuigen en de sector zware industrie van respectievelijk 7,2 en 7,0 miljard euro. Voor alle sectoren is de totale handelsbalans netto positief voor de rest van de EU-27.

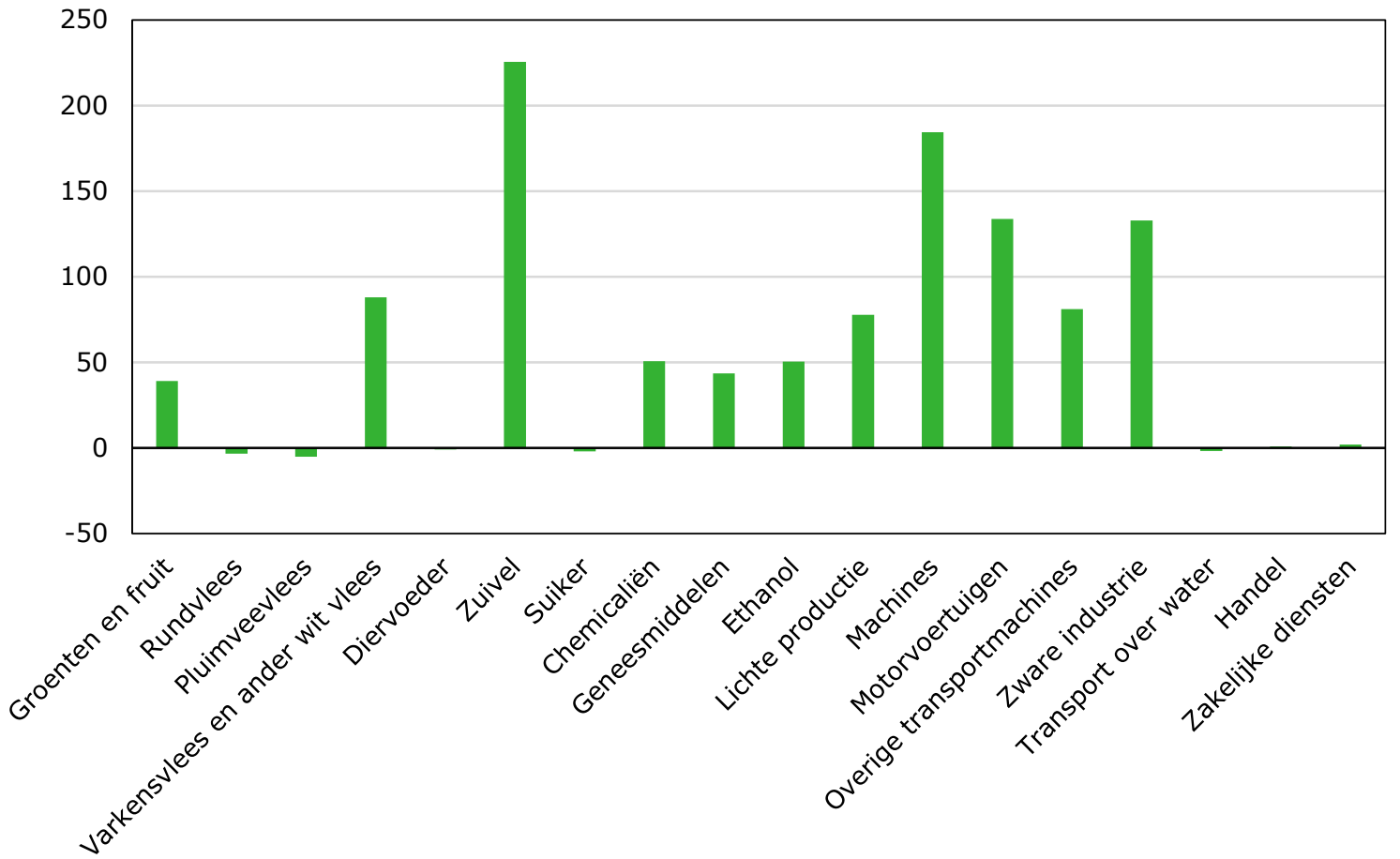

Figuur 3.16 Verschil in groei van de export van de rest van de EU-27 naar de vier Mercosurlanden in de periode 2020-2035 onder het Mercosur-akkoord, \% 


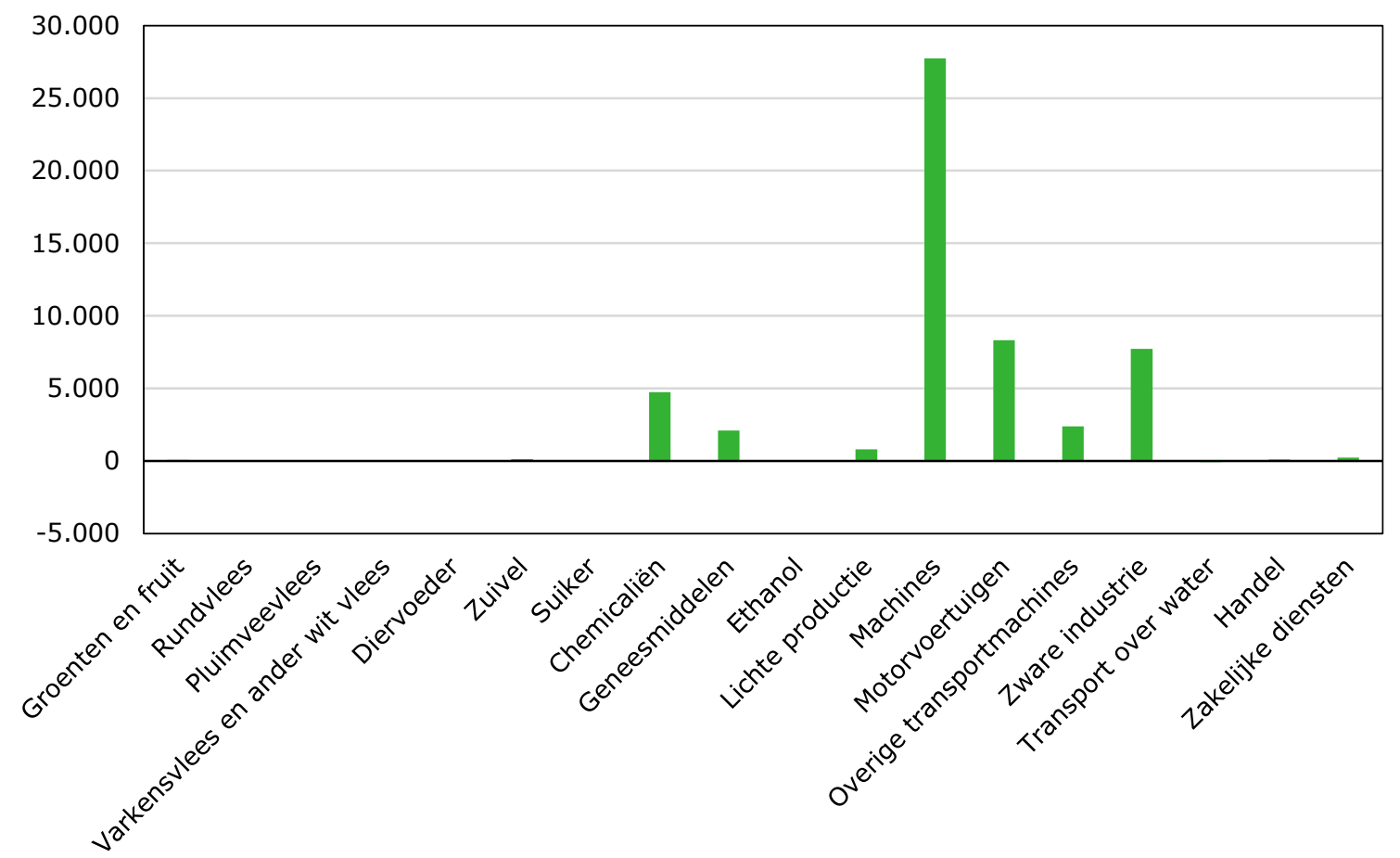

Figuur 3.17 Groei van de export van de rest van de EU-27 in 2035 naar de vier Mercosur-landen onder het Mercosur-akkoord, in miljoenen $€$

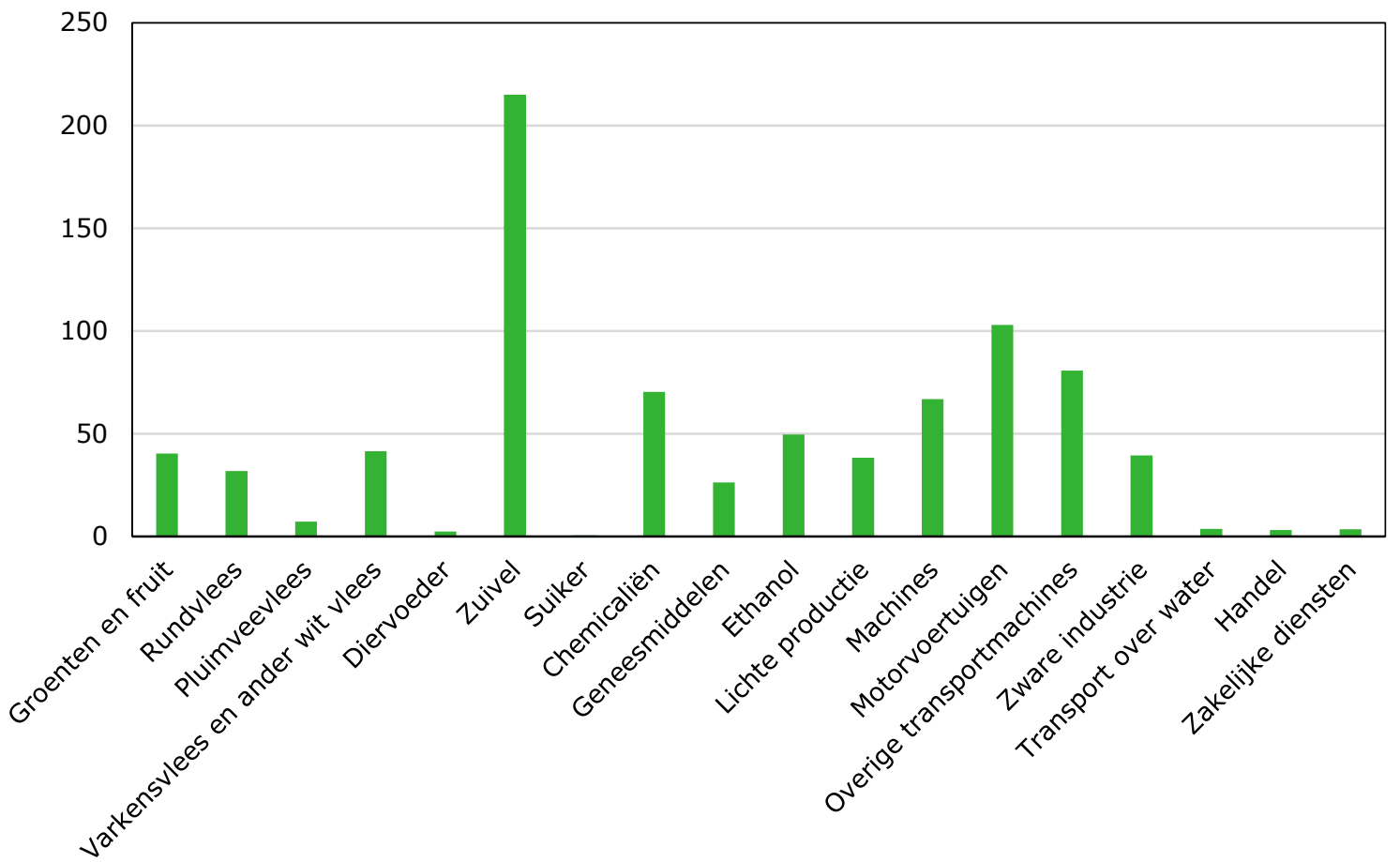

Figuur 3.18 Verschil in groei van de import in de rest van de EU-27 uit de vier Mercosur-landen in de periode 2020-2035 onder het Mercosur-akkoord, \% 


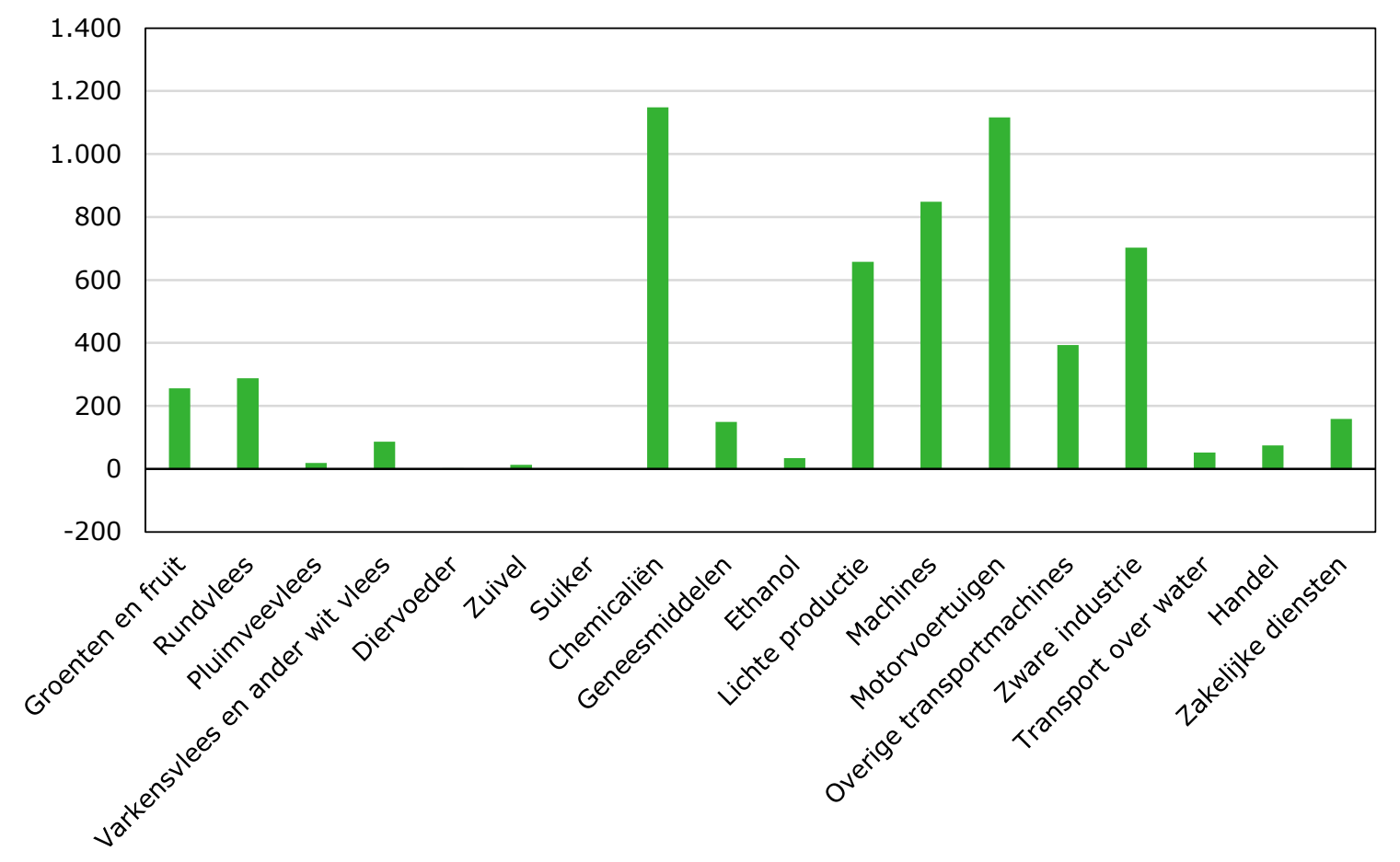

Figuur 3.19 Groei van de import van de rest van de EU-27 in 2035 uit de vier Mercosur-landen onder het Mercosur-akkoord, miljoenen $€$

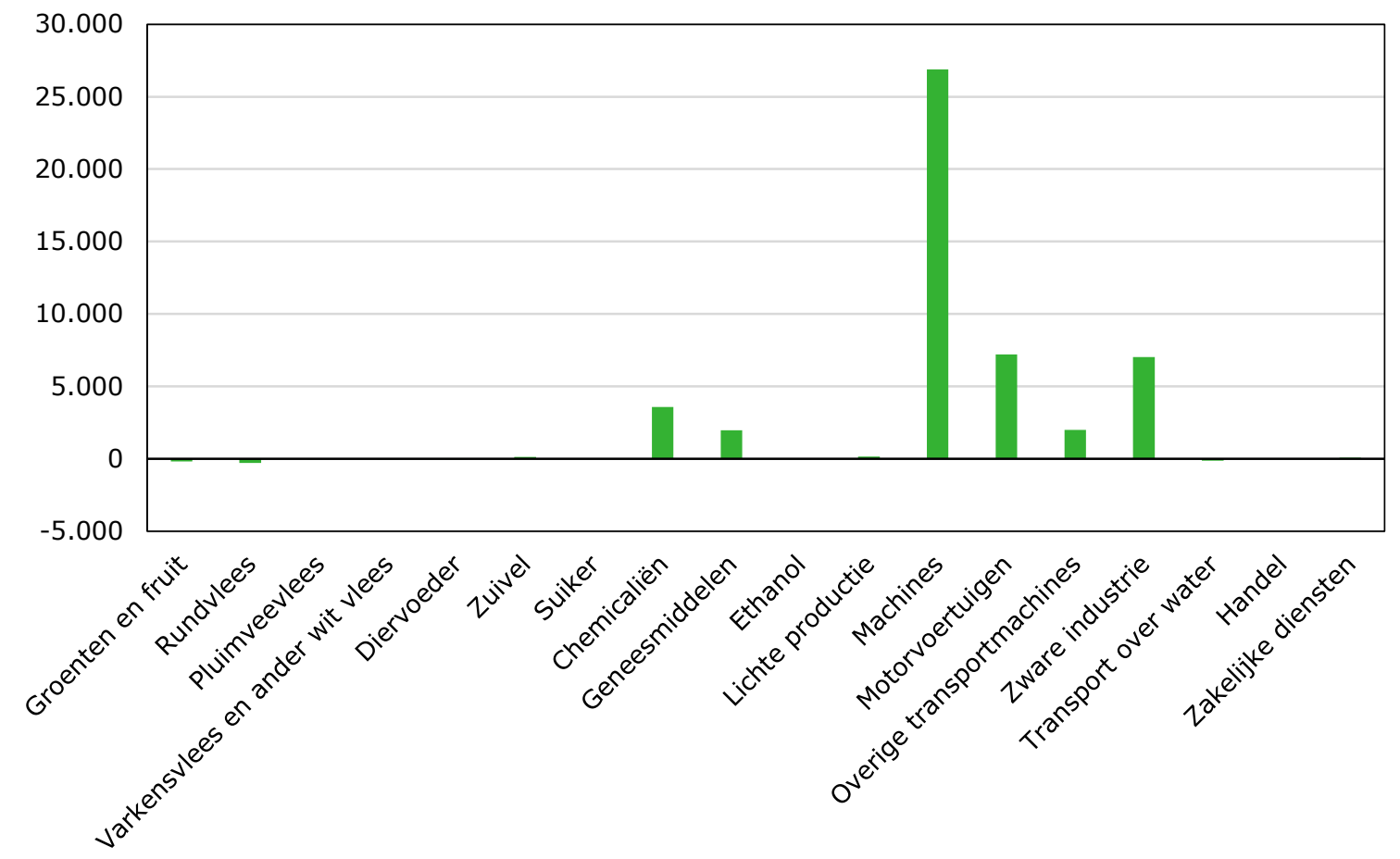

Figuur 3.20 Verandering van de handelsbalans tussen de rest van de EU-27 en Mercosur in 2035 onder het Mercosur-akkoord, miljoenen $€$ 


\subsection{Conclusies uit de modellering}

Op macroniveau worden er voor Nederland, evenals voor de overige EU-27-landen, slechts minimale effecten verwacht door het EU-Mercosur-akkoord, geschat op basis van tariefreducties, gewijzigde tariefcontingenten en de beperking van NTM-gerelateerde handelsbarrières. Dat de macroeconomische effecten over het algemeen gering zijn, heeft vooral te maken met de samenstelling van de Europese economie. De meeste output is afkomstig uit de dienstensectoren, die met meer dan twee derde van de totale economische output in Europa de grootste sectorgroep vormen. Het ligt niet in de verwachting dat de dienstensectoren uitbreiden als gevolg van het akkoord. Hoewel de Nederlandse economie voor een groot deel op dienstverlening drijft, wordt er toch een beperkte groei verwacht in de handel naar Mercosur-landen aangezien de handel in diensten tussen Mercosur-landen toeneemt. Deze uitkomsten komen overeen met de beperkte macro-economische effecten die worden gepresenteerd in het Mercosur Agreement Impact Assessment (LSE, 2020).

Op sectorniveau zijn er echter wel effecten, die met name in de agrifoodsector groter uitvallen dan in de productie- en dienstverlenende industrie. De effecten zijn vooral van belang voor de Nederlandse rundvleessector, die aanvankelijk te maken heeft met de hoogste import exposure in vergelijking met de andere vergeleken sectoren. Daarom wordt deze sector na de liberalisering geconfronteerd met een grotere concurrentie door meer import vanuit de vier Mercosur-landen. Met de rundvleessector krimpt dan ook de bijbehorende primaire sector, de rundveehouderij.

Alle producten die ingevoerd worden in de EU moeten voldoen aan de EU-normen voor voedselveiligheid, en aan de veterinaire en fytosanitaire EU-normen. Door verschillen in de gehanteerde SPS-normen ${ }^{22}$ komt er momenteel geen varkensvlees uit de Mercosur-landen naar Europa. De vermelde geaggregeerde groei van de import in de sector varkensvlees en ander wit vlees geeft daarom alleen de toename in de import van ander wit vlees weer. Om deze reden wordt de sectorkrimp alleen verwacht in de deelsector ander wit vlees. Zo zal ook de geraamde stijging van de rundvleesimport uit de Mercosur-landen naar Europa afhangen van naleving van SPS-normen in overeenstemming met EU-regelgeving. Met andere woorden, als de exporteurs uit de Mercosur-landen zich niet aan de EU-normen houden, komt deze vleesimport de EU niet binnen.

Ondertussen krijgen productiesectoren voet aan de grond op de Mercosur-markt, waardoor de Nederlandse en Europese export toeneemt en de export naar Mercosur voor de machinebouwsector naar verwachting sterk zal groeien. Tegelijkertijd blijkt uit de resultaten dat de concurrentie tussen Mercosur-landen onderling naar verwachting zal toenemen als gevolg van het akkoord. Om de niettarifaire barrières te verminderen, zouden de Mercosur-landen een hervorming van de regelgeving moeten doorvoeren. Dit zou een belangrijke verandering betekenen, niet alleen gunstig voor Europese exporteurs, maar ook concurrentieversterkend binnen de Mercosur-markt zelf versterken.

\footnotetext{
${ }^{22}$ Ractopamine is een diervoedertoevoeging om magerheid te bevorderen en de voedselconversie te verbeteren. In Brazilië is het gebruik hiervan toegestaan, maar in de EU is er een verbod op. Brazilië beweert ractopaminevrij varkensvlees te produceren, maar bij EU-controles van de afgelopen jaren werd deze stof nog steeds aangetroffen in een aanzienlijk deel van de monsters uit slachtvarkens. Zodoende wordt er geconcludeerd dat het bestaande systeem nog niet degelijk genoeg is om te garanderen dat er geen ractopamine wordt gebruikt (VVB, 2013). Bovendien blijkt uit het verslag van het VVB dat de Braziliaanse wetgeving geen regels bevat voor de identificatie van varkens en dat de controle- en bemonsteringsprocedures voor de productie van ractopaminevrij varkensvlees bestemd voor export naar de EU niet de hele productieketen bestrijken.
} 


\section{$4 \quad$ Effecten van het handelsakkoord op de inkomsten van Nederlandse agrarische gezinsbedrijven}

\section{$4.1 \quad$ Inleiding}

In de parlementaire motie uit 2019 is expliciet gevraagd om inzicht in de effecten van het akkoord op de inkomsten van agrarische gezinsbedrijven ${ }^{23}$ in de vlees- en zuivelsectoren. In dit hoofdstuk worden de resultaten van het handelsakkoord per sector gebruikt om in te schatten wat de effecten zijn op de inkomsten van de hoofdtypes agrarische bedrijven die vallen onder het Bedrijveninformatienet ${ }^{24}$ van $^{2}$ Wageningen Economic Research. Om deze effecten in te schatten worden de veranderingen in agrarische prijzen en volumes door de implementatie van het Mercosur-handelsakkoord volgens de MAGNET-modelsimulatie uit het vorige hoofdstuk geïmplementeerd in een model op bedrijfsniveau. ${ }^{25}$

Zoals eerder aangegeven resulteert deze analyse uitsluitend in primaire effecten en zonder rekening te houden met de effecten van mogelijke veranderingen in het gedrag van boeren (bijv. een innovatie die leidt tot meer opbrengst), veranderingen in de prijs van land of kapitaal of structurele veranderingen in de sector (dus veranderingen in de grootte van de onderneming, de structuur hoeveel en welke gewassen worden verbouwd - en toegepaste technologie) in de loop van de tijd. Met deze vereenvoudigde aanpak simuleren we geen inkomsten op bedrijfsniveau in het basisscenario voor 2035, aangezien dit vraagt om een aantal belangrijke aannames wat betreft de hierboven genoemde punten die bij dit onderzoek buiten beschouwing zijn gelaten. Anderzijds zijn de effecten op de inkomsten door het Mercosur-handelsakkoord gerelateerd aan het huidige inkomen en worden de effecten dus getoond alsof het Mercosur-akkoord direct en volledig is geïmplementeerd, oftewel alsof de inkomsten op bedrijfsniveau in het basisscenario voor 2035 (zonder Mercosur-akkoord) gelijk waren aan het gemiddelde van 2016-2018 (onze huidige startsituatie).

De prijsveranderingen door het Mercosur-akkoord op bedrijfsniveau zijn relatief klein, variërend van 0,0 tot $-0,8 \%$ voor alle (13) primaire producten die in de MAGNET-modelsimulatie uit hoofdstuk 3 zijn meegenomen, wat vervolgens leidt tot minimale veranderingen in productie. De gecombineerde prijs- en volumeveranderingen van de productcategorieën waar onze inkomsteneffectanalyse op is gericht, zijn samengevat in tabel 4.1. De veranderingen zijn het grootst voor bedrijven die vleesrunderen en/of kalveren houden en nihil voor zuivel- en varkensbedrijven, gegeven dat de verwachte import van deze producten uit Mercosur verwaarloosbaar zijn (zie paragraaf 3.4 voor uitleg). Diervoederprijzen vallen iets lager uit vanwege minder of geen exporttarieven die Argentinië hanteert op sojaschroot.

Tabel 4.1 Toegepaste veranderingen in prijs en volume (\%) per productcategorie

\begin{tabular}{ll}
\hline Suikerbiet & $-0,38$ \\
\hline Vleesvee (rund) & $-0,82$ \\
\hline Vleesvee (kalf) & 0,00 \\
\hline Pluimvee (vlees en eieren) & $-0,14$ \\
\hline Varken & 0,00 \\
\hline Rauwe melk & $-0,05$ \\
\hline Diervoeder & $-0,29$
\end{tabular}

Bron: onze eigen berekeningen met MAGNET.

\footnotetext{
${ }^{23}$ De effecten op prijs en volume zijn, op een paar zeer grote bedrijven na, allemaal gerelateerd aan gezinsbedrijven. Enkel bij glastuinbouw is er sprake van (veel) bedrijven die bestaan uit een rechtspersoon met werknemers.

${ }^{24}$ Het Bedrijveninformatienet is een gestratificeerde steekproef waarbij agrarische bedrijven per grootte en type (strata) zijn opgenomen. Ga voor meer informatie naarhttps://www.wur.nl/nl/Onderzoek-Resultaten/WettelijkeOnderzoekstaken/Centrum-voor-Economische-Informatievoorziening-1/Land-en-tuinbouw. htm Bedrijven-Informatienet van $A$ tot $Z$.

${ }^{25}$ Dit is een rekentool die is gebaseerd op individuele prijs- en volumedata uit het Bedrijveninformatienet. De rekentool kan per (type) agrarisch bedrijf simuleren wat het effect van prijs- en volumeveranderingen is op omzet, kosten en inkomsten.
} 
Er is een belangrijke kanttekening bij de prijseffecten die zijn gesimuleerd voor de vleesveesector. Rund- en kalfsvlees zijn in het MAGNET-model samengevoegd tot één sector. Dat resulteert in één geschatte prijs voor de twee producten, terwijl het in feite twee zeer verschillende soorten vlees zijn. Witkalfsvlees is bijvoorbeeld een luxeproduct van hoogwaardige kwaliteit, dat voor veel hogere prijzen wordt verkocht dan 'gemiddeld' rundvlees. Ook rosékalfsvlees is relatief duur vergeleken met rundvlees. De markt voor kalfsvlees verschilt sterk van die voor rundvlees wat betreft marktsegment en exportfocus - Italië en Frankrijk zijn grote afnemers - waarbij kwaliteit, en niet prijs, de onderscheidende factor is. Bovendien is de productie in hoge mate verticaal geïntegreerd, waardoor de hele sector voordelen geniet door schaalgrootte en prijsschokken kan opvangen. (Bakker et al., 2012; Berkhout et al., 2019). ${ }^{26}$ Daarnaast exporteert Mercosur geen kalfsvlees naar de EU en de verwachting is dat dit door het handelsakkoord ook niet zal veranderen. De effecten van het akkoord op de EU-markt voor kalfsvlees zullen daarom indirect zijn via effecten op de markten voor rund- en ander soort vlees met invloed op de vraag in de EU naar kalfsvlees. Op basis van deze factoren nemen we aan dat de verkoopprijs van kalfsvlees niet wordt beïnvloed door het handelsakkoord tussen de EU en Mercosur.

\subsection{Koppeling van prijsveranderingen ${ }^{27}$ aan soorten landbouwbedrijven}

De prijseffecten zijn gekoppeld aan vlees (rund, kalf, varken en pluimveevlees), melk, suiker en diervoeder. Dat wil zeggen dat het prijseffect van verschillende soorten vlees op de omzet van rundvlees, varkensvlees en pluimveevlees van ieder individueel bedrijf wordt toegepast, en ook het prijseffect van melk, suiker en diervoeder op de omzet uit melk en suikerbiet en op de kosten van ingekocht diervoeder. Deze effecten worden vertaald naar (gespecialiseerde) zogeheten NSObedrijfstypes ${ }^{28}$ waar ze het meeste effect zullen hebben. Deze types zijn akkerbouw-, melkvee-, varkens-, vleeskuiken-, legkippen-, vleeskalveren- en vleesveebedrijven. Daarnaast onderscheiden we een overige groep met daarin schapen-, paarden- en geitenbedrijven, gemengde bedrijven (die niet vallen onder de overige akkerbouw en dierhouderij) en tuinbouwbedrijven (kassen en volle grond).

Tabel 4.2 toont een overzicht van het aantal bedrijven per bedrijfstype in Nederland. Voor ieder bedrijfstype is een nominaal opbrengstniveau aangegeven, wat een indicatie geeft van de grootte van het bedrijf in duizenden euro's en staat voor een standaardoutput (SO) op jaarbasis. Dit maakt het mogelijk om de economische prestaties van verschillende bedrijven te vergelijken. In de onderstaande tabel wordt ook de term 'Agrarische inkomsten per onbetaalde arbeidsjaareenheid (AJE)' gebruikt. Dit is een vergoeding die de boer en zijn huishouden ontvangen voor het gebruik van hun arbeid en kapitaal in het bedrijf. Het geeft ook het aantal onbetaalde arbeidsjaareenheden aan per bedrijfstype voor een gemiddeld bedrijf. Dit is relatief hoog voor melkvee- en legkippenbedrijven, wat betekent dat meer gezinsleden bijdragen aan het bedrijfsresultaat, in vergelijking met andere bedrijfstypes. Een driejaarlijks gemiddelde wordt gebruikt als referentie, omdat inkomsten sterk kunnen variëren per jaar. Dit neemt grote toevallige verschillen tussen de bedrijfstypes weg.

\footnotetext{
${ }^{26}$ Ongeveer twee derde van de kalfsvleesproductie gebeurt onder contract, de boer krijgt hierbij een vergoeding voor het houden van de dieren, energiekosten, afvoer van mest enz., waarbij de opdrachtgever eigenaar is van de kalveren en ook het diervoeder aanlevert. De vergoedingen voor contractboeren zijn de laatste jaren redelijk stabiel gebleven, maar de verkoopprijzen fluctueerden en de EU-subsidies zijn afgenomen. Dat duidt erop dat de prijsveranderingen van kalfsvlees voornamelijk door de marges van de opdrachtgever zijn opgevangen. Van de prijs van kalfsvlees dat niet onder contract wordt geproduceerd wordt aangenomen dat het dezelfde ontwikkelingen ondergaat als vlees dat wel onder contract wordt geproduceerd.

${ }^{27}$ In deze en de volgende paragraaf gebruiken we de term 'prijseffect' voor gezamenlijke veranderingen in prijs en volume zoals te zien in tabel 4.1. De totale omzetverandering (prijs- en volume-effect) is van belang omdat de inkomsten over prijs en volume gaan.

${ }^{28} \mathrm{NSO}=$ Nederlandse standaardoutput Zie bijlage 3 voor een toelichting van deze bedrijfstypes.
} 
Tabel 4.2 Inkomsten per onbetaalde arbeidsjaareenheid, aantal AJE's, Standaardoutput (SO) en aantal bedrijven; gemiddelden van 2016, 2017 en 2018; voor geselecteerde bedrijfstypes

\begin{tabular}{|c|c|c|c|c|c|}
\hline & Aantal bedrijven & $\begin{array}{r}\text { so }(x 1.000 \\
\text { euro })\end{array}$ & $\begin{array}{r}\text { Inkomsten uit } \\
\text { bedrijven per } \\
\text { onbetaalde AJE }\end{array}$ & $\begin{array}{r}\text { Aantal } \\
\text { onbetaalde } \\
\text { AJE's }\end{array}$ & $\begin{array}{r}\text { Inkomsten per } \\
\text { bedrijf (x } 1.000 \\
\text { euro })\end{array}$ \\
\hline Melkveebedrijven & 16.040 & 433 & 39 & 1,6 & 61 \\
\hline Varkensbedrijven & 2.220 & 907 & 82 & 1,1 & 93 \\
\hline Legkippenbedrijven & 640 & 839 & 75 & 1,6 & 121 \\
\hline Vleeskalverenbedrijven & 1.230 & 669 & 31 & 1,3 & 40 \\
\hline Vleesveebedrijven & 3.480 & 75 & -14 & 0,9 & -13 \\
\hline Overige bedrijven & 13.850 & 780 & 97 & 1,4 & 139 \\
\hline Totaal & 45.270 & 524 & 59 & 1,4 & 81 \\
\hline
\end{tabular}

Bron: Bedrijveninformatienet Wageningen Economic Research. Zie bijlage 3 voor uitleg over de bedrijfstypen, so, inkomsten per onbetaalde arbeidsjaareenheid.

Uit de tabel is het volgende op te maken:

- de hoeveelheid SO is het laagst voor grondgebonden bedrijven (akkerbouw-, melkvee- en vleesveebedrijven).

- inkomsten uit bedrijven variëren sterk tussen de verschillende types: de inkomsten uit vleeskuikenbedrijven zijn bijvoorbeeld relatief hoog, terwijl de inkomsten uit melkvee- en vleeskalverenbedrijven relatief laag zijn.

- de inkomsten uit de groep vleesveebedrijven zijn zelfs negatief. Deze groep bestaat voornamelijk uit hobbybedrijven met een klein aantal vlees- en graasdieren, bijvoorbeeld melkveebedrijven die een groot deel van hun bedrijf hebben verkocht (grond en melkkoeien) maar nog steeds slachtvee houden op een kleinere schaal.

\subsection{Effect van prijs- en volumeveranderingen op bedrijfsinkomsten per bedrijfstype}

Prijs- en volumeveranderingen die voortkomen uit de implementatie van het handelsakkoord tussen de EU en Mercosur zullen veranderingen in opbrengsten teweegbrengen. Voor de diersectoren worden ook veranderingen in de kosten van diervoeder door prijsveranderingen in granen en oliezaden (beide belangrijke bestanddelen van diervoeder) meegenomen. De diersectoren hebben baat bij enigszins goedkoper diervoeder (zie ook tabel 4.1).

Tabel 4.3 vat de inkomstenconsequenties samen (veranderingen in inkomsten, rekening houdend met veranderende kosten van diervoeder waarbij alle andere kosten gelijk blijven). Er zijn negatieve inkomsteneffecten te zien voor vleeskalveren- en vleesveebedrijven waar dit effect optreedt bij de eerstgenoemde bedrijven omdat die ook volwassen vleesvee houden. In absolute hoeveelheden zijn de negatieve effecten gemiddeld 800 euro voor vleeskalverenbedrijven en 700 euro voor vleesveebedrijven. Bijna alle pluimvee- en varkensbedrijven zien voordelen door de lagere voederprijzen, maar toch is het inkomsteneffect gemiddeld laag met gemiddeld 700 euro voor vleeskuikenbedrijven, 1.200 euro voor legkippenbedrijven en 2.100 euro voor varkensbedrijven (zie tabel 4.3 bovenaan). 
Tabel 4.3 Inkomsteneffecten en -verdeling van bedrijven naar inkomstenklasse-effecten ( $x$ 1.000 euro) per bedrijfstype

\begin{tabular}{|c|c|c|c|c|c|c|}
\hline & $\begin{array}{r}\text { (veranderingen t.0.v. } \\
\text { gemiddelde } \\
\text { inkomsten } 2017 \text { - } \\
2019 \text { ) }\end{array}$ & \multicolumn{5}{|c|}{$\begin{array}{c}\text { Inkomsteneffecten in intervallen: gemiddeld inkomsteneffect } \\
\text { van bedrijven waarvan het inkomsteneffect terugviel in het } \\
\text { interval }\end{array}$} \\
\hline \multicolumn{7}{|c|}{ Inkomsteneffect (x 1.000 euro) } \\
\hline Akkerbouwbedrijven & $-0,2$ & n.v.t. & 0 & $-0,2$ & n.v.t. & n.v.t. \\
\hline Melkveebedrijven & $-0,1$ & 0,2 & n.v.t. & $-0,1$ & n.v.t. & n.v.t. \\
\hline Varkensbedrijven & 2,1 & 2,1 & 0 & $-0,1$ & n.v.t. & n.v.t. \\
\hline Vleeskuikenbedrijven & 0,7 & 0,8 & n.v.t. & $-0,2$ & n.v.t. & n.v.t. \\
\hline Legkippenbedrijven & 1,2 & 1,5 & 0,0 & 0,0 & n.v.t. & n.v.t. \\
\hline Overige bedrijven & 0,1 & 0,9 & 0,0 & $-0,2$ & n.v.t. & n.v.t. \\
\hline Totaal & 0,2 & 1,1 & 0,0 & $-0,2$ & $-3,6$ & $-6,9$ \\
\hline \multicolumn{7}{|c|}{ Verdeling van bedrijven (horizontaal $=100 \%$ ) } \\
\hline Akkerbouwbedrijven & 100 & 0 & 15,4 & 84,6 & 0 & 0 \\
\hline Melkveebedrijven & 100 & 16,6 & 0 & 83,4 & 0,9 & 0 \\
\hline Varkensbedrijven & 100 & 87,6 & 5,4 & 6,8 & 0 & 0 \\
\hline Vleeskuikenbedrijven & 100 & 99 & 0 & 1 & 0 & 0 \\
\hline Legkippenbedrijven & 100 & 84,3 & 15,6 & 0 & 0 & 0 \\
\hline Vleeskalverenbedrijven & 100 & 54,1 & 0,0 & 36,5 & 5,5 & 4,1 \\
\hline
\end{tabular}

Bron: Bedrijveninformatienet Wageningen Economic Research. nvt = niet van toepassing.

De grootte van bedrijven verschilt per bedrijfstype en ook per hoeveelheid inkomsten. Grotere bedrijven zijn in het nadeel als de prijs van hun producten lager worden en de kosten gelijk blijven (of minder afnemen dan de opbrengsten). Om inzicht te krijgen in welke bedrijven het meest worden getroffen door het handelsakkoord, geeft tabel 4.3 een overzicht van de inkomsteneffecten voor een aantal intervallen, en een gemiddeld inkomsteneffect per bedrijfstype en hoeveel bedrijven te kampen hebben met verminderde inkomsten gedurende een interval. Uit de tabel is het volgende op te maken:

- $88 \%$ van de varkensbedrijven heeft een positief effect met een gemiddelde toename van

2.100 euro. Er zijn geen bedrijven met een inkomstenverlies van meer dan 2.500 euro.

- Bijna alle vleeskuikenbedrijven boeken een positief resultaat. $84 \%$ van de legkippenbedrijven ondervindt een positief effect met een gemiddelde toename van 1.500 euro, het overige deel ondervindt geen inkomsteneffect.

- $36 \%$ van de vleeskalverenbedrijven ondervindt een inkomstenverlies van gemiddeld 1.500 euro en $10 \%$ heeft een negatief inkomsteneffect van gemiddeld meer dan 2.500 euro. De rest - 54\% - boekt een zeer klein positief resultaat.

- De meerderheid (91\%) van de vleesveebedrijven boekt een klein verlies van gemiddeld 700 euro per bedrijf; $8 \%$ van de bedrijven heeft zelfs een positief effect (door de lagere voederkosten), hoewel erg weinig in absolute hoeveelheden.

- De effecten op bijna alle melkvee- en akkerbouwbedrijven zijn negatief, bijna allemaal respectievelijk 100 en 200 euro.

- Voor alle bedrijfstypes zijn er gemiddeld gezien geen negatieve inkomsteneffecten.

Tabel 4.4 toont nogmaals welke verschillen er zijn tussen grote of grotere en kleine of kleinere bedrijven. Het bovengenoemde concept SO (genormaliseerde opbrengst per bedrijf) wordt gebruikt om de grenzen tussen grote en kleine bedrijven te bepalen (zie voetnoot in de tabel). Uit tabel 4.4 blijkt dat de verschillen voor akkerbouw-, melkvee-, varkens-, pluimvee- en vleesveebedrijven klein zijn tussen de kleine en grote bedrijven, maar dat de grotere vleeskalverenbedrijven duidelijk meer negatieve inkomsteneffecten ondervinden. Dit komt omdat die bedrijven ook een aanzienlijk aantal 
volwassen vleesrunderen houden, waarvoor negatieve kosteneffecten zijn geschat als gevolg van het handelsakkoord.

Tabel 4.4 Verdeling van inkomsteneffecten over aangegeven intervallen, voor kleine en grote bedrijven, per bedrijfstype (\%)

\begin{tabular}{|c|c|c|c|c|c|c|}
\hline & $\begin{array}{l}\text { Gemiddeld } \\
\text { inkomsteneffect }\end{array}$ & $\begin{array}{r}\text { Positief } \\
\text { effect }\end{array}$ & $\begin{array}{l}\text { Geen } \\
\text { effect }\end{array}$ & $-2,5-0$ & $-5--2,5$ & $<-5$ \\
\hline \multicolumn{7}{|c|}{ Aandeel kleine bedrijven a) } \\
\hline Akkerbouwbedrijven & 100 & 0 & 17 & 83 & 0 & 0 \\
\hline Melkveebedrijven & 100 & 16 & 0 & 84 & 0 & 0 \\
\hline Varkensbedrijven & 100 & 82 & 8 & 10 & 0 & 0 \\
\hline Vleeskuikenbedrijven & 100 & 100 & 0 & 0 & 0 & 0 \\
\hline Legkippenbedrijven & 100 & 88 & 11 & 1 & 0 & 0 \\
\hline Vleeskalverenbedrijven & 100 & 49 & 0 & 45 & 5 & 1 \\
\hline Vleesveebedrijven & 100 & 8 & 0 & 91 & 0 & 0 \\
\hline Overige bedrijven & 100 & n.v.t. & n.v.t. & N.v.t. & n.v.t. & n.v.t. \\
\hline Totaal & 100 & 29 & 54 & 17 & 0 & 0 \\
\hline \multicolumn{7}{|c|}{ Aandeel grote bedrijven a) } \\
\hline Akkerbouwbedrijven & 100 & n.v.t. & n.v.t. & N.v.t. & n.v.t. & n.v.t. \\
\hline Melkveebedrijven & 100 & 0 & 9 & 91 & 0 & 0 \\
\hline Varkensbedrijven & 100 & 100 & 0 & 0 & 0 & 0 \\
\hline Vleeskuikenbedrijven & 100 & 98 & 0 & 2 & 0 & 0 \\
\hline Legkippenbedrijven & 100 & 78 & 18 & 5 & 0 & 0 \\
\hline Vleeskalverenbedrijven & 100 & 74 & 0 & 2 & 9 & 15 \\
\hline Vleesveebedrijven & 100 & 16 & 72 & 12 & 0 & 0 \\
\hline Overige bedrijven & 100 & 21 & 21 & 58 & 0 & 0 \\
\hline Totaal & 100 & n.v.t. & n.v.t. & n.v.t. & n.v.t. & N.v.t. \\
\hline
\end{tabular}

a) voor akkerbouw-, melkvee-, vleeskalveren- en vleesveebedrijven is de So-grenswaarde 300.000 euro, voor alle andere types 1 miljoen euro. Bron: Bedrijveninformatienet Wageningen Economic Research.

Samengevat is het gemiddelde inkomsteneffect per bedrijf positief voor varkens- en pluimveebedrijven en nagenoeg nul voor melkvee- en akkerbouwbedrijven. De inkomsteneffecten zijn negatief voor vleesvee- en vleeskalverenbedrijven. Het gemiddeld inkomsteneffect per vleeskalverenbedrijf is 800 euro, oftewel een afname van $2 \%$ van het gemiddelde inkomstenniveau van 2017-2019. Voor vleesveebedrijven is het geschatte negatieve inkomsteneffect 700 euro, wat neerkomt op een afname van 5,4\% van de gemiddelde inkomsten per bedrijf (tabel 4.5).

Tabel 4.5 Inkomsten per bedrijf (2017-2019), inkomsteneffecten door het akkoord en het aandeel van inkomsten in de gemiddelde inkomsten per bedrijf (gemiddelde van 2017-2019), per bedrijfstype

\begin{tabular}{lrrr} 
& $\begin{array}{r}\text { Inkomen per bedrijf } \\
(1.000 \text { euro) }\end{array}$ & $\begin{array}{r}\text { Inkomsteneffect }(1.000 \\
\text { euro })\end{array}$ & $\begin{array}{r}\text { Aandeel inkomsteneffect } \\
\text { van } \begin{array}{r}\text { gemiddelde } \\
2017-2019 \\
\text { inkomsten } \\
(\%)\end{array}\end{array}$ \\
Akkerbouwbedrijven & 58 & $-0,2$ & $-0,3$ \\
\hline Melkveebedrijven & 61 & $-0,1$ & $-0,2$ \\
\hline Varkensbedrijven & 93 & 2,1 & 2,3 \\
\hline Vleeskuikenbedrijven & 136 & 0,7 & 0,5 \\
\hline Legkippenbedrijven & 121 & 1,2 & 1,0 \\
\hline Vleeskalverenbedrijven & 40 & $-0,8$ & $-2,0$ \\
\hline Vleesveebedrijven & -13 & $-0,7$ & $-5,4$ \\
\hline Overige bedrijven & 139 & 0,1 & 0,1 \\
\hline Totaal & 81 & 0,1 & 0,1 \\
\hline
\end{tabular}

Bron: Bedrijveninformatienet Wageningen Economic Research. 


\section{$5 \quad$ Belangrijkste uitkomsten}

In reactie op de motie van Voordewind c.s., aangenomen door de Tweede Kamer op 4 juli 2019, geeft dit onderzoek een kwantitatieve analyse van het EU-Mercosur-handelsakkoord dat op 28 juni 2019 is ondertekend. In het akkoord bereiken de EU en Mercosur overeenstemming over: tariefliberalisering van bijna alle producten (resp. 95\% en $91 \%$ van de tarieflijnen) binnen 15 jaar na in werking treding van het akkoord; implementatie van nieuwe tariefcontingenten; en faciliteren van de markt via andere afspraken. Hoewel de Nederlandse handelsrelaties met Mercosur beperkt zijn (export naar Mercosur is 2,3\% van de totale export naar landen buiten de EU), verwachten Nederlandse exporteurs voordelen te behalen uit de tariefliberalisering, aangezien alle EU-exporteurs relatief hoge tarieven moeten betalen om de Mercosur-markt te betreden. Daarnaast wordt verwacht dat de handel wordt gestimuleerd door nieuwe tariefcontingenten die Mercosur onder het akkoord implementeert op kaas, melkpoeder en babymelkpoeder.

De tariefliberalisering en nieuwe contingenten zijn belangrijke onderdelen van het akkoord, maar ook afspraken over betere afstemming van regelgeving en standaarden, zoals deze onder meer in SPS en TBT hoofdstukken van het akkoord zijn weergegeven. De afspraken lijken echter nog weinig doelgericht waardoor het niet duidelijk is in hoeverre met de afspraken in het akkoord SPS- en TBTgerelateerde problemen die EU-exporteurs nu ondervinden in de Mercosur-markt tot het verleden zullen behoren. Ook vertegenwoordigers van het Nederlandse bedrijfsleven en stakeholders uit landbouw- en industriële sectoren betwijfelen in hoeverre dit akkoord non-tarifaire belemmeringen voor handel zal wegnemen.

Met het MAGNET-model zijn effecten doorgerekend van het EU-Mercosur-akkoord op macro-economisch en sectorniveau bij hypothetisch volle implementatie in 2035. Hierbij zijn de veranderingen in tarieven en exportheffingen op macroniveau berekend uit het (afgesproken) schema voor markttoegang, nieuwe en verbeterde tariefcontingenten zijn geïmplementeerd en NTM's zijn gemodelleerd met schattingen van de Wereldbank en de OESO. Prijs- en volumeveranderingen op macroniveau uit MAGNET zijn ingevoerd in een model op bedrijfsniveau om effecten op bedrijfsinkomsten te bepalen.

De verwachte macro-effecten van het EU-Mercosur-akkoord zijn klein voor zowel Nederland als de rest van de EU-27, met een stijging van het Nederlandse bbp van 0,03\% en 0,02\% voor de rest van de EU-27. De resultaten weerspiegelen de samenstelling van de Europese economie. De meeste output is afkomstig uit de dienstensectoren, waarin meer dan twee derde van de totale economische output in Europa wordt geproduceerd. De belangrijkste prijsstijgingen van het akkoord komen door de tariefliberalisering en tariefcontingenten, welke met name landbouw- en industriegoederen betreffen. Landbouw en de industriesector vormen echter een klein deel van de totale economische output in Nederland, en de gevolgen van het akkoord voor deze sectoren dragen slechts in beperkte mate bij aan de effecten voor de hele economie.

Op sectorniveau is er meer variatie in de effecten, met stijgingen en dalingen afhankelijk van de mate waarin sectoren betrokken zijn bij import en/of export. In Nederland hebben de productiesectoren relatief meer export exposure naar de Mercosur-markt en de landbouwsectoren meer relatieve import exposure. De sectoren voor overige transportmiddelen (geen motorvoertuigen) en geneesmiddelen hebben de meeste relatieve export exposure en breiden hun productie uit met respectievelijk $1,42 \%$ en $1,16 \%$ door toegenomen export naar Mercosur. Daar staat tegenover dat de sectoren voor rundvlees en groente en fruit beide relatief hoge import exposure hebben. De productie in deze sectoren daalt met respectievelijk $0,61 \%$ en $0,21 \%$. Zo neemt de productie in de veesector af met $0,49 \%$, in navolging op de afname in de vleesveesector. Een belangrijke kanttekening is dat de importgroei vanuit Mercosur naar Europa vanwege de verschillen in SPS-normen in de EU en Mercosur afhankelijk zal zijn van naleving van de EU-wetgeving voor voedselveiligheid en SPS-normen. Hoewel de handelseffecten variëren per sector neemt de handelsbalans tussen Nederland en Mercosur netto toe door het akkoord, wat wil zeggen dat de export naar Mercosur sneller groeit dan de import uit Mercosur. 
De inkomsteneffecten op bedrijfsniveau worden negatief ingeschat voor gespecialiseerde vleeskalverenbedrijven ( -800 euro) en vleesveebedrijven (gemiddeld -700 euro). Daarbij treden de negatieve effecten met name op bij grotere vleeskalverenbedrijven waar ook een aanzienlijke hoeveelheid volwassen vleesrunderen worden gehouden. Pluimvee- en varkensbedrijven profiteren van lagere diervoederprijzen, met een positief inkomsteneffect voor legkippen-, vleeskuiken- en varkensbedrijven van respectievelijk gemiddeld $1.200,700$ en 2.100 per bedrijf. Als kanttekening bij deze uitkomsten moet worden gemeld dat er geen rekeningen is gehouden met de structuurveranderingen van de sector door de tijd heen. Daarom zijn de veranderingen in opbrengsten wel meegenomen, maar veranderingen in schaalgrootte en kosten niet. 


\section{Literatuur en websites}

Aguiar, A., M. Chepeliev, E. Corong, R. McDougall, and D. van der Mensbrugghe (2019). 'The GTAP Data Base: Version 10'. Journal of Global Economic Analysis, 4(1), 1-27.

Armington, P. (1969). A Theory of Demand for Products Distinguished by Place of Production. Staff Papers (International Monetary Fund), 16(1), 159-178.

AVEC (Association of Poultry Processors and Poultry Trade in the EU Countries) (2020). Annual report 2019. AVEC, Brussels

Bakker, T., W. Baltussen and B. Doorneweert (2012). 'Competitive position of the white veal meat sector'. LEI report 2012-025. LEI-Wageningen UR. The Hague.

Benz, S., and A. Jaax (2020), 'The costs of regulatory barriers to trade in services: New Estimates of Ad Valorem Tariff Equivalents', OECD Trade Policy Papers, No. 238.

Berkhout, P., J. Jager and B. Smit (2019). Inkomenseffecten van de GLB-aanpassingen per 2020; Een quick scan. Wageningen, Wageningen Economic Research, Rapport 2019-114. 42 blz.; 5 fig.; 8 tab.; 12 ref.

Berkum, S. van (2015). Prospects of an EU-Mercosur trade agreement for the Dutch agrifood sector. LEI Wageningen UR report 2015-036.

De Janvry, A., M. Fafchamps, and E. Sadoulet (1991). 'Peasant Household Behavior with Missing Markets: Some Paradoxes Explained', Economic Journal, 101: 1400-1417.

DG (SANTE), (2013). Final report of an audit carried out in Brazil from 02 May 2017 to 12 May 2017 in order to evaluate the operations of controls over the production of beef, horse and poultry meat, and products derived therefrom intended for export to the European Union. Ref.

Ares(2017)4608632 - 21/09/2017. DG(SANTE) 2017-6261

DG (SANTE), (2018). Final report of an audit carried out in Brazil from 22 January to 05 February 2018 in order to follow up the implementation of the actions taken by the Brazilian authorities to address the recommendations of audit report DG(SANTE)/2017-6261. Ref. Ares(2018)3139259 - 14/06/2018. DG(SANTE) 2018-6460

Disdier, A.-C., C. Emlinger, and J. Fouré (2016), 'Interdependencies between Atlantic and Pacific agreements: Evidence from agri-food sectors', Economic Modelling, Vol. 55: 241-253.

Dixon, P., H. van Meijl, M. Rimmer, L. Shutes, and A. Tabeau (2016). 'RED versus REDD: Biofuel policy versus forest conservation', Economic Modelling, 52: 366-374.

EC (2020). New EU-Mercosur trade agreement. The agreement in principle. Brussels, 1 July 2019. European Commission. DG Trade. https://trade.ec.europa.eu/doclib/docs/2019/june/tradoc_157964.pdf

EC (2019), EU agricultural outlook for markets and income, 2019-2030. European Commission, DG Agriculture and Rural Development, Brussels.

FVO (Food and Veterinary Office). (2013). Final report of an audit carried out in Brazil from 15 to 28 October 2013 in order to evaluate the operations of control over the production of fresh bovine meat destined for export to the European Union as well as certification procedures. European Commission. Health and Consumers Directorate-General. DG(SANCO) 2013-6886 - MR FINAL. Ref. Ares(2014)1109368 - 09/04/2014

Horne, P van (2018). Competitiveness of the EU poultry meat sector. Wageningen UR. Report 2018-116.

Jafari, Y., and D. Tarr (2015), 'Estimates of Ad Valorem Equivalents of Barriers Against Foreign Suppliers of Services in Eleven Services Sectors and 103 Countries', World Economy, Vol. 40(3): 544-573.

Kee, H. L., and A. Nicita (2017), 'Trade Frauds, Trade Elasticities and Non-Tariff Measures', Mimeo.

LSE (2020), 'Sustainability Impact Assessment in Support of the Association Agreement Negotiations between the European Union and Mercosur', Draft Final Report July 2020.

Nowicki, P., V. Goba, A. Knierim, H. van Meijl, M. Banse, B. Delbaere, J. Helming, P. Hunke, K., Jansson, T. Jansson, L. Jones-Walters, V. Mikos, C. Sattler, N. Schlaefke, I. Terluin, and D. Verhoog (2009). 'Scenar 2020-II - Update of Analysis of Prospects in the Scenar 2020 Study', European Commission, Directorate-General Agriculture and Rural Development, Brussels. 
OECD/FAO (2020), OECD-FAO Agricultural Outlook 2020-2029, FAO, Rome/OECD Publishing, Paris,

https://doi.org/10.1787/1112c23b-en.

UNCTAD (2013). Non-tariff measures to trade: Economic and policy issues for developing countries. UNCTAD New York and Geneva

UNCTAD, 2017. Non-tariff measures in Mercosur: deepening regional integration and looking beyond. UNCTAD, New York and Geneva

USDA (2019). EU biofuels Annual 2019. GAIN Report Number:NL9022. 7/15/2019

Van Meijl, H., T. van Rheenen, A. Teabeau, and B. Eickhout (2006). 'The impact of different policy environments on agricultural land use in Europe', Agriculture, Ecosystems \& Environment, 114(1): 21-38.

Woltjer, G., M. Kuiper, A. Kavallari, H. van Meijl, J. Powell, M. Rutten, L. Shutes, and A. Tabeau (2014). 'The MAGNET model - Module description', LEI, Wageningen University \& Research. LEI Report 14-057.

WTO (2020). WTO Tariff download facility. www. tariffdata.wto.org 


\section{Bijlage 1 Motie Voordewind}

\section{Tweede Kamer der Staten-Generaal}

Vergaderjaar 2018-2019

34952 Investeren in Perspectief - Goed voor de Wereld, Goed voor Nederland Nr. 75

\section{MOTIE VAN HET LID VOORDEWIND C.S.}

Voorgesteld 4 juli 2019

De Kamer, gehoord de beraadslaging,

- constaterende dat er een politiek akkoord bereikt is over het handelsverdrag tussen de EU en Mercosur-landen;

- overwegende dat in maart 2011 de motie-Koopmans/Snijder-Hazelhoff (21501-32, nr. 460) is aangenomen, die de regering onder andere verzocht niet in te stemmen met een associatieakkoord tussen de Europese Unie en de Mercosur-landen zolang de effecten voor de land- en tuinbouw niet kwantitatief in kaart zijn gebracht;

- constaterende dat Nederlandse boeren, met name in de rundvlees- en pluimveesector, hard getroffen kunnen worden wanneer het nu voorliggende associatieakkoord met de Mercosur-landen in werking treedt;

- overwegende dat in het regeerakkoord is afgesproken dat Nederland internationaal met andere koplopers streeft naar verbetering van het dierenwelzijn en dat bij handelsverdragen niet wordt getornd aan de Europese standaarden voor voedselveiligheid en consumentenbescherming;

- constaterende dat het toelaten van producten tot de Europese markt die niet aan onze duurzaamheids- en dierenwelzijnsmaatstaven voldoen, kan leiden tot oneerlijke concurrentie;

- constaterende dat de Europese Unie toegezegd heeft de markt in deze gevoelige sectoren te monitoren op marktverstoringen en middelen heeft toegezegd voor flankerend beleid;

verzoekt de regering, zodra de geconsolideerde teksten beschikbaar zijn, maar uiterlijk voor de behandeling in de Raad van de Europese Unie, de voor- en nadelen van de handel met de Mercosurlanden onder dit handelsverdrag voor de Europese land- en tuinbouw en in het bijzonder voor de Nederlandse (gezins)bedrijven in de vlees- en zuivelsector, kwantificeerbaar in kaart te brengen;

verzoekt de regering tevens, om in de debatten in de Raad van de Europese Unie erop aan te dringen dat de Europese Unie tot vastlegging komt van de huidige EU/VN-standaarden in het trade and sustainable development chapter, inclusief voedselveiligheid, dierenwelzijn, het Klimaatakkoord en het tegengaan van ontbossing, alsook zal aandringen op de effectieve uitvoering ervan in de Mercosurlanden;

verzoekt de regering vervolgens, om in debat te gaan met de Kamer over de finale verdragstekst alvorens de regering het verdrag namens Nederland zal accorderen,

en gaat over tot de orde van de dag.

Voordewind, Amhaouch, Bouali, Van Haga

Tweede Kamer, vergaderjaar 2018-2019, 34 952, nr. 752

bron: https://www.parlementairemonitor.nl/9353000/1/j9vvij5epmj1ey0/vkzxbmccoezt\#p1 


\section{Bijlage 2}

Schatting van de

handelskosten door niet-

tarifaire maatregelen:

literatuuronderzoek naar gegevensbronnen, econometrische schattingen en implementatie in CGEmodelsimulaties

\section{Inleiding}

Niet-tarifaire maatregelen (NTM's) zijn beleidsmaatregelen, naast tarieven of tariefcontingenten, die direct of indirect economische effecten kunnen hebben op de handelsstromen tussen landen. Handelsakkoorden zoals tussen de EU en Mercosur bevatten ingrijpende bepalingen die rechtstreeks van invloed zijn op niet-tarifaire maatregelen (NTM's), hetzij door de toepassing van strengere wettelijke voorschriften (bijv. SPS en TBT), hetzij door het opheffen van wettelijke barrières (bijv. markten openstellen voor buitenlandse concurrentie). NTM's kunnen ook aanzienlijke gevolgen hebben voor de handel in goederen, maar vooral voor de handel in diensten zijn NTM's belangrijk, aangezien er voor diensten geen op tarieven gebaseerde handelsbarrières bestaan.

Bij de beoordeling van handelsakkoorden worden er grondige analyses uitgevoerd om niet alleen de effecten van wijzigingen in de tarieven en tariefcontingenten in kaart te brengen, maar ook die van wijzigingen in NTM's. Tarieven zijn vanzelfsprekend vooral cijfermatig van aard, maar bij niet-tarifaire maatregelen is dit vaak niet zo. Daarom is er een econometrische schatting nodig om de geraamde effecten van NTM's op de handelsstromen te bepalen, en vervolgens wordt dit effect op de handelsstromen vertaald in een ad-valoremequivalent (AVE) oftewel het tariefequivalent van de handelskosten door de NTM's.

Een veelgebruikt instrument voor de beoordeling van handelsakkoorden is het CGE-model (berekenbaar algemeen evenwicht, computable general equilibrium), een klasse van modellen waarbij de internationale handelsstromen (bestaande uit consumptie en productie) worden gekoppeld aan de economieën van de afzonderlijke landen. Om veranderingen in NTM's te kunnen verwerken in een CGE-beoordeling van een handelsakkoord zijn er twee belangrijke elementen nodig: (1) cijfermatige schattingen van NTM's, en (2) een manier om deze cijfers in het model te implementeren. De beschikbare cijfermatige schattingen (1) en de modelcode zelf zijn beide van invloed op de beschikbare opties voor modelimplementatie (2).

In deze bijlage bespreken we de literatuur en gegevensbronnen over NTM's die worden gebruikt als basis voor de modellering van NTM's in het MAGNET-model (Modular Applied GeNeral Equilibrium Tool) als onderdeel van de beoordeling van het handelsakkoord tussen de EU en Mercosur. In deel 2 beoordelen we gegevensbronnen en econometrische schattingen voor niet-tarifaire maatregelen voor goederen en diensten. Verder bekijken we in deel 3 de implementatie van NTM-modellen voor goederen en diensten. In deel 4 doen we op basis van onze bevindingen over schattingen en modelleringstechnieken aanbevelingen voor NTM-implementatie in het MAGNET-model. 


\section{Gegevensbronnen en schattingen}

In dit deel bespreken we de gegevensbronnen, en welke econometrische schattingen er zijn uitgevoerd om AVE-schattingen voor NTM's te ontwikkelen. Wat betreft goederen is de Conferentie van de Verenigde Naties voor handel en ontwikkeling (UNCTAD) de belangrijkste voor schattingen gebruikte NTM-gegevensbron. De twee belangrijkste bronnen van econometrische schattingen voor AVE-schattingen zijn de Wereldbank en de Organisatie voor Economische Samenwerking en Ontwikkeling (de OESO). Voor diensten verzamelen de Wereldbank en de OESO hun eigen gegevens over NTM's en voeren zij hun eigen schattingen uit. Er is een recenter initiatief van de Wereldbank in samenwerking met de Wereldhandelsorganisatie (WTO) om nieuwe gegevens over diensten te verzamelen, maar de laatste NTM-schattingen van de Wereldbank dateren van hiervoor en zijn gebaseerd op het oorspronkelijke initiatief van de Wereldbank.

\section{a. Goederen}

\section{UNCTAD}

De UNCTAD verzamelt NTM-gegevens volgens de Internationale classificatie van niet-tarifaire maatregelen (UNCTAD 2019), die voor het laatst is herzien in 2017. Dit classificatiesysteem is overeengekomen door de MAST-groep (Multi-Agency Support Team), ${ }^{29}$ een groep deskundigen van acht multilaterale instellingen. De gegevens worden verspreid via de 6-cijferige productindeling van het geharmoniseerd systeem (GS) in de database van het Trade Analysis and Information System (TRAINS) van de UNCTAD. ${ }^{30}$ De indeling van NTM's op het niveau van de tarieflijn (GS) vergemakkelijkt het onderzoek naar de effecten van NTM's op de handelsstromen voor een bepaalde GS-lijn. Deze gegevens worden door de Wereldbank en de OESO als belangrijkste input gebruikt voor de schattingen van NTM-AVE's.

\section{Wereldbank}

Kee et al. (2009) is een invloedrijk artikel op het gebied van NTM AVE-schattingen. De auteurs produceren unilaterale waardemetingen van AVE's voor goederen-NTM's voor 93 importerende landen en voor 4941 GS-codes op het 6-cijferige indelingsniveau. Vanuit hun econometrische model berekenen zij twee soorten AVE's: (1) een 'kern'-AVE, en (2) een landbouwkundige binnenlandse ondersteunende AVE. De gegevens die worden gebruikt voor de schatting van de kern-AVE zijn afkomstig van UNCTAD TRAINS. Hierbij gaat het o.a. om de volgende niet-tarifaire barrières: prijsbeheersingsmechanismen, kwantitatieve beperkingen, monopolistische maatregelen en technische voorschriften. De informatie over binnenlandse steun is afkomstig uit de kennisgevingen van WTOleden tussen 1995 en 1998.

Kee en Nicita (2017) leveren bilaterale maatregelen van NTM-AVE's voor 41 importerende landen uit 152 landen van herkomst en voor 40 GTAP-codes (indelingsversie 9). Zij leveren twee maatregelen voor schattingen: (1) AVE's van technische maatregelen en (2) AVE's van niet-technische maatregelen. Overeenkomstig de internationale indeling van niet-tarifaire maatregelen, omvatten de technische maatregelen: sanitaire en fytosanitaire maatregelen en technische maatregelen. Verder omvatten de niet-technische maatregelen: handelscontingenten, kwantitatieve beperkingen, prijsbeheersing en financiële bepalingen.

\section{OESO}

Cadot et al. (2018) leveren bilaterale maatregelen voor goederen-NTM-AVE's voor 86 landen en voor meer dan 5000 GS-codes op het 6-cijferige indelingsniveau. Naast de geschatte AVE's (prijseffecten) schatten de auteurs ook de volume-effecten in, waarmee de effecten van NTM's op de eenheidswaarden van handel worden aangegeven. Naast het GS-indelingsniveau zijn er schattingen beschikbaar voor 41 GTAP-sectoren (indelingsversie 9). Voor zowel de prijs- als de volume-effecten leiden deze tot vier soorten maatregelen voor schattingen: (1) sanitaire en fytosanitaire (SPS)maatregelen, (2) technische handelsbarrières (TBT), (3) grenscontrolemaatregelen (BCM's) en (4) kwantitatieve beperkingen (QR's).

\footnotetext{
${ }^{29}$ https://unctad.org/en/Pages/DITC/Trade-Analysis/Non-Tariff-Measures/MAST-Group-on-NTMs.aspx

${ }^{30}$ https://unctad.org/en/Pages/DITC/Trade-Analysis/Non-Tariff-Measures/NTMs-Data.aspx
} 


\section{b. Diensten}

\section{OESO}

Sinds 2014 verzamelt de dienstenafdeling van de OESO jaarlijks uitgebreide informatie over handelsbeperkingen en 'achter de grens'-regelgeving die van invloed is op de handel in diensten en verstrekt zij kwantitatieve maatregelen van dit beleid in de restrictiviteitsindex voor de handel in diensten van de OESO (Services Trade Restrictiveness Index, STRI). Deze STRI vormt een maat voor het relatieve niveau van en de verschillen tussen de beleidsmaatregelen die van invloed zijn op de handel in diensten en omvatte in 2019 bijna 98000 regelgevingsposten in 22 sectoren en in 46 landen. De regelgeving is ingedeeld in vijf brede beleidsgebieden: (1) beperkte toegang vanuit het buitenland, (2) beperkingen op het verkeer van personen, (3) andere discriminerende maatregelen, (4) concurrentiebarrières en (5) transparantie van de regelgeving (OESO 2020).

Op basis van het STRI-onderzoek (Benz en Jaax, 2020) schat de OESO de AVE's voor handelsbarrières voor diensten voor 44 importerende landen en 5 GTAP-codes (indelingsversie 9). De STRI-score meet de relatieve barrière van de binnenlandse regelgeving voor buitenlandse concurrenten, en daarom zijn de AVE's een unilaterale maat voor de handelskosten van alle handelspartners van een importeur. Hiervan uitgezonderd zijn leden van de Europese Economische Ruimte (EER), waarvoor er twee schattingsreeksen zijn: (1) voor EER-handelspartners en (2) voor niet-EER-handelspartners.

\section{Wereldbank - Wereldhandelsorganisatie}

De STRI van de Wereldbank is in eerste instantie voor 2008 samengesteld op basis van

(1) vragenlijsten die door lokale advocatenkantoren zijn ingevuld voor 79 niet-OESO-landen en (2) openbaar beschikbare informatie voor 24 OESO-landen, waaronder de verslagen van de WTO, de OESO en het Internationaal Monetair Fonds (IMF). Voor deze 103 landen zijn gegevens verzameld uit vijf grote sectoren: telecommunicatie, financiën, transport, detailhandel en professionele diensten (Borchet et al., 2012).

In samenwerking met de WTO is het STRI van de Wereldbank voor 68 WTO-leden geactualiseerd voor 2016. Voor de 25 niet-OESO-economieën werden opnieuw gegevens verzameld uit vragenlijsten die door lokale advocatenkantoren waren ingevuld. Voor de 43 OESO-economieën werden de gegevens rechtstreeks uit de STRI-databank van de OESO gehaald. De nieuwe Wereldbank - WTO STRI bestrijkt dezelfde vijf brede sectoren als de oorspronkelijke STRI van de Wereldbank en rapporteert bovendien op een verder uitgesplitst niveau van 23 sectoren (Borchet et al., 2019).

Op basis van de STRI van de Wereldbank van 2008 hebben Jafari en Tarr (2015) dienstenbarrièreAVE's voor alle 103 landen geschat. Zij geven schattingen voor 11 dienstensectoren: boekhouding, juridische zaken, luchtvervoer, spoorwegvervoer, wegvervoer, zeevervoer, verzekeringen, bankwezen, vaste telefonie, mobiele telefonie en detailhandel. De AVE-schattingen zijn unilateraal, om dezelfde redenen als hierboven beschreven.

\section{Implementatie in modellen}

In dit hoofdstuk bespreken we methoden voor de invoering van NTM's in CGE-modellen. In het bijzonder overwegen we de toepassing van NTM-modelleringsmethoden die ook geschikt zijn voor de analyse van toekomstige handelsakkoorden. We bespreken de NTM-implementatie voor de goederenen de dienstensector.

De implementatie van NTM's in CGE-simulatiemodellen berust in eerste instantie op de representatie binnen het model. De meest voorkomende weergave van NTM's in CGE-modellen is een weergave met een efficiëntieparameter, het zogeheten 'ijsbergeffect'. Door dit mechanisme worden zowel de importprijzen als de volumes beïnvloed (Sanjuan Lopez et al., 2019).

Een andere benadering is het afbeelden van NTM's in CGE-modellen als zuivere prijseffecten vanwege belastingen op import of export, die als indicatief kunnen worden beschouwd voor de huurgenererende effecten van NTM's (Fugazza en Maur, 2008). Disdier et al. (2016) passen zo'n aanpak toe en 
combineren deze met de 'ijsberg'-aanpak. Zowel bij toepassing alleen of in combinatie met het 'ijsbergeffect' is een nadeel dat de getalsmatige benadering zonder empirisch bewijs voor de huurprijzen van NTM's afhankelijk dreigt te worden van willekeurige aannames.

Andere benaderingen zijn gebaseerd op theoretische innovaties die niet standaard zijn in de meeste CGE-modellen. Zo introduceren Walmsley en Minor (2019) nieuwe mechanismen waardoor de consument ook om goederen met hogere prijzen kan vragen. Het idee is dat consumenten bereid zijn hogere prijzen te betalen voor bepaalde normen die via bepaalde NTM's worden geïntroduceerd (bijv. SPS).

Gezien de representatie van NTM's in de theorie van het CGE-model is het tweede belangrijke element de interpretatie en dus de toepassing van de beschikbare schattingen van de effecten van NTM's. Van oudsher wordt bij de analyse van de handelsakkoorden normaliter rekening gehouden met de openstelling van de handel en dus met een vermindering van de NTM's. In de afgelopen tijd wordt er echter onderzoek gedaan naar de situatie bij een toename van de NTM's, zoals bij analyses van de Brexit (Arriola et al., 2018; Smith et al., 2019). In het kader van het handelsakkoord tussen de EU en Mercosur overwegen wij een analyse van NTM-vermindering.

De standaardbenadering van de interpretatie en toepassing van NTM's is gebaseerd op de 'ijsbergrepresentatie' in het CGE-model en op de geschatte AVE's van NTM's. Eerst moet de gewenste reductie worden gespecificeerd. Dit zou algemeen kunnen worden toegewezen, bijvoorbeeld door ervan uit te gaan dat een daling van $10 \%$ van de handelskosten vanuit NTM's neerkomt op een verhoging van de 'ijsbergefficiëntie' met $10 \%$ (LSE, 2020). Het zou specifieker zijn om de daling van de handelskosten naar een toename van de efficiëntie op soortgelijke wijze te bepalen voor elke bilaterale productstroom, en daarbij gebruik te maken van geschatte AVE's voor NTM's.

Om de relatieve niveaus bij de wijzigingen in efficiëntie te specificeren, kunnen variaties in de NTMAVE-schattingen worden benut. In een illustratief onderzoek van de OESO (2019) wordt bijvoorbeeld gebruikgemaakt van de OESO-AVE's van diensten om een mogelijke liberalisering van de dienstensector in alle G20-landen te onderzoeken. De OESO maakt gebruik van het verschil tussen AVE's voor EER-leden en AVE's voor niet-EER-leden, met de gedachte dat het gemiddelde AVE-niveau binnen de EER het resultaat vormt van decennialange samenwerking op het gebied van regelgeving tussen de leden. Om dit scenario te modelleren, beschouwen zij het verschil in AVE-schatting per land en per sector ten opzichte van het EER-referentiepunt als de 'ijsbergefficiëntie'-verbetering die nodig is om de benchmark te bereiken.

Een aanvullende overweging om de haalbaarheid van beleidswijzigingen te beoordelen, die van invloed zijn op de handelsbeperking van NTMS of op de 'actionability' (uitvoerbaarheid). Francois et al. (2015) zijn bijvoorbeeld van mening dat slechts $50 \%$ van de opgelegde NTM-beperkingen daadwerkelijk kan worden gereduceerd, en ze implementeren in hun eigen modellen een reductie van $25 \%$ van het NTMniveau. Disdier et al. (2016) zijn daarentegen van mening dat zelfs een verbetering van $25 \%$ wellicht niet haalbaar is en passen slechts een verbetering van $10 \%$ toe op de handelsbeperkingen door NTM's.

\section{Implementatie met MAGNET}

Op basis van ons literatuuronderzoek hebben we NTM's in het MAGNET-model geïmplementeerd om het EU-Mercosur-akkoord te kunnen beoordelen. We specificeren deze implementatie enerzijds (1) in schattingen van NTM-AVE's voor goederen en diensten, en anderzijds (2) in geïmplementeerde modelleringsmethoden. We hebben daarbij rekening gehouden met de beschikbaarheid van gegevens en met de hieraan te stellen eisen in het kader van de beoordeling van het akkoord tussen de EU en Mercosur.

Wat betreft de NTM-AVE-schattingen voor goederen heeft de OESO-databank zoals geschat door Cadot et al. (2018) de meeste gegevens te bieden qua landendekking (86 importeurs met bilaterale stromen) en gepresenteerde schattingen (vier soorten AVE's plus volume-effecten). Helaas zijn de 
OESO-schattingen niet beschikbaar gemaakt op bilateraal niveau. Daarom zijn de schattingen van Kee en Nicita (2017) gebruikt. De resultaten zijn beschikbaar op het sectorniveau van GTAP, dat we dan in MAGNET aan de sectoren koppelen.

Voor diensten kunnen er conclusies uit de databases getrokken worden, waarbij een gecombineerde aanpak noodzakelijk is. De STRI-index van de OESO is op dit moment het duidelijke referentiepunt voor informatie over handelsbeperkingen op diensten, waarbij het STRI-initiatief van de Wereldbank en de WTO rechtstreeks uit de OESO-bron put. De OESO-schattingen voor 2020 (Benz en Jaax, 2020) zijn de meest recente bron van AVE-schattingen van barrières op diensten. Voor de Mercosur-landen zijn deze schattingen echter alleen beschikbaar voor Brazilië. Toch vormen ze een belangrijke en rijke bron van informatie voor Nederland en Europa met AVE's voor EER- en niet-EER-partners. Daarom hebben we zowel de schattingen van dienstenbarrières van de OESO als de schattingen van de Wereldbank gebruikt, met cijfers uit Argentinië, Paraguay en Uruguay (Jafari en Tarr, 2015).

Wat betreft de toepassing implementeren we de standaard CGE-modelleringsaanpak, waarbij AVENTM-schattingen worden gecombineerd met de 'ijsbergefficiëntie'-aanpak, net als bij de OESO (2019). We maken gebruik van het verschil tussen de landenspecifieke niveaus van de NTM's in Mercosur en die binnen de EER voor hetzelfde product. Aangenomen dat het akkoord tot een zekere mate van standaardisering leidt, zouden we dus aannemen dat het niveau van de NTM's in Mercosur tot een zekere hoogte in de buurt komt van het niveau in de EU. Dit verschilt natuurlijk per land en product (en per partner voor de goederen-NTM's), in tegenstelling tot bij het doorvoeren van een vlakke verandering van $10 \%$ in NTM's tussen landen en producten. Verder houden we, volgens Disdier et al. (2016), rekening met een niveau van 10\% 'actionability' (uitvoerbaarheid).

\section{Verwijzingen naar bijlage 2}

Arriola, C., C. Carrico, D. Haugh, N. Pain, E. Rusticelli, D. Smith, F. van Tongeren, and B. Westmore (2018), 'The Potential Macroeconomic and Sectoral Consequences of Brexit on Ireland', OECD Economics Department Working Papers No. 1508.

Benz, S., and A. Jaax (2020), 'The costs of regulatory barriers to trade in services: New Estimates of Ad Valorem Tariff Equivalents', OECD Trade Policy Papers, No. 238.

Borchet, I., B. Gootiiz, and A. Mattoo (2012), 'Guide to the Services Trade Restrictions Database', World Bank Policy Research Working Paper 6108.

Borchert, I., B. Gootiiz, J. Magdeleine, J. Marchetti, A. Mattoo, E. Rubio, and E. Shannon (2019), 'Applied Services Trade Policy: A Guide to the Services Trade Policy Database and Services Trade Restrictions Index', WTO Staff Working Paper ERSD-2019-14.

Cadot, O., J. Gourdon and F. van Tongeren (2018), 'Estimating Ad Valorem Equivalents of Non-Tariff Measures: Combining Price-Based and Quantity-Based Approaches', OECD Trade Policy Paper No. 215.

Disdier, A.-C., C. Emlinger, and J. Fouré (2016), 'Interdependencies between Atlantic and Pacific agreements: Evidence from agri-food sectors', Economic Modelling, Vol. 55: 241-253.

Fugazza, M. and J.-C. Maur (2009), 'Non-Tariff Barriers in Computable General Equilibrium Modelling', United Nations Policy Issues in International Trade and Commodities Study Series No. 38.

Francois, J., M. Manchin, H. Norberg, O. Pindyuk, and P. Tomberger (2015), 'Reducing transatlantic barriers to trade and investment: An economic assessment', Working Paper, No. 1503, Johannes Kepler University of Linz, Department of Economics, Linz.

Jafari, Y., and D. Tarr (2015), 'Estimates of Ad Valorem Equivalents of Barriers Against Foreign Suppliers of Services in Eleven Services Sectors and 103 Countries', World Economy, Vol. 40(3): 544-573.

Kee, H.L., A. Nicita, and M. Olarreaga (2009), 'Estimating Trade Restrictiveness Indices', Economic Journal, Vol. 119(534): 172-199.

Kee, H.L., and A. Nicita (2017), 'Trade Frauds, Trade Elasticities and Non-Tariff Measures', Mimeo.

LSE (2020), 'Sustainability Impact Assessment in Support of the Association Agreement Negotiations between the European Union and Mercosur', Draft Final Report.

OECD (2019), 'Trade Policy and the Global Economy - Scenario 4: Addressing Barriers to Services Trade', OECD Trade and Agriculture Directorate Policy Brief.

OECD (2020), 'OECD Services Trade Restrictiveness Index: Policy trends up to 2020', OECD Trade and Agriculture Directorate Brochure. 
Sanjuan Lopez, A., M. Rau, and G. Woltjer (2019), 'Exploring alternative approaches to estimate the impact of non-tariff measures and further implementation in simulation models', JRC Technical Report No JRC113883.

Smith, D., C. Arriola, C. Carrico, and F. van Tongeren (2019), 'The potential economic impact of Brexit on the Netherlands', OECD Economics Department Working Papers No. 1518.

UNCTAD (2019), International Classification of Non-Tariff Measures: 2019 Version, United Nations Symbol: UNCTAD/DITC/TAB/2019/5.

Walmsley, T., and P. Minor (2019), 'Demand shifts and willingness to pay in applied trade models', World Economy, early view. 


\title{
Bijlage 3 Gebruikte begrippen bij de berekening van de effecten op bedrijfsniveau in hoofdstuk 4
}

\author{
NSO-typologie \\ De mate van specialisatie van een bedrijf, het NSO-bedrijfstype (Nederlandse standaardoutput), wordt \\ berekend op basis van het aandeel van de standaardoutput (SO) per productgroep in het totaal. Deze \\ groepering is in eerste instantie onderverdeeld in vijf sectoren: akkerbouw, tuinbouw, meerjarige \\ teelten, graasdieren en veehouderij.
}

Afhankelijk van het aandeel van de SO van de productgroepen van het bedrijf wordt het NSOhoofdtype bepaald. Voor elk van de vijf bovengenoemde sectoren stellen we dat een bedrijf is gespecialiseerd in één ervan indien het aandeel van die sector in de SO van het bedrijf meer dan $2 / 3$ bedraagt. Indien geen van de afzonderlijke sectoren een groter aandeel heeft dan $2 / 3$, wordt het bedrijf ingedeeld in een van de drie groepen van gecombineerde bedrijven. Deze verhouding van $2 / 3$ geldt ook voor de subtypes binnen de varkens en het pluimvee. Op de vleeskuikenbedrijven moet ten minste $2 / 3$ van de totale omvang van de SO bestaan uit vleeskuikens.

\section{So-normen}

De definitie van de standaardoutput komt overeen met die van de standaardoutput die vanaf 2010 in de Europese statistieken (inclusief de landbouwstructuurenquête) en het Bedrijveninformatienet wordt gebruikt. Het is een bedrag in euro per bedrijf en vertegenwoordigt een gestandaardiseerde jaarlijkse output (productievolume $x$ prijs). De standaardoutput (in euro per bedrijf) is de totale omvang van een bedrijf en wordt berekend als de som van de standaardoutput van alle gewassen en dieren. Bij de totale bedrijfsomvang wordt geen rekening gehouden met inkomsten uit bijvoorbeeld subsidies, rechtstreekse steun aan landbouwbedrijven en multifunctionele activiteiten.

\section{Inkomsten uit de landbouw per onbetaalde arbeidseenheid per jaar}

De vergoeding die de ondernemers en hun gezin hebben ontvangen voor het gebruik van hun arbeid en kapitaal op het bedrijf. De inkomsten worden berekend door de totale inkomsten van het bedrijf af te trekken van de uitgaven en afschrijvingen en daar het saldo van de buitengewone baten en lasten bij op te tellen. De index wordt meestal uitgedrukt in euro per onbetaalde arbeidsjaareenheid (onbetaalde AJE), waarmee hij gekoppeld is aan de hoeveelheid ingezette arbeidskrachten en dus beter vergelijkbaar is tussen bedrijven.

\section{Arbeidsjaareenheid}

De AJE (arbeidsjaareenheid) is een maat voor de ingezette arbeid. Eén AJE komt overeen met 2.000 gewerkte uren, waarbij 1 persoon maximaal 1 AJE kan vormen. De uren die zijn gebruikt voor de berekening van het aantal AJE's zijn gecorrigeerd voor 'volwaardigheid': er worden correcties aangebracht voor jongeren en ouderen.

\section{So versus inkomen per bedrijfstype}

Vergeleken met grondgebonden landbouwbedrijven hebben intensieve veehouderijbedrijven een grote omvang in gemeten SO (tabel 4.1 in de hoofdtekst). De kleinere marges (veel toegerekende kosten) laten een inkomen over dat over een langere periode vergelijkbaar is met dat van andere bedrijfstypen. In de periode $2016-2018$ is het inkomen op de meeste intensieve veehouderijbedrijven hoger dan op grondgebonden landbouwbedrijven. Dit heeft te maken met het feit dat de prijzen in die periode bovengemiddeld waren. 


\section{Andere uitgangspunten}

Voor de vleeskalverenbedrijven onder contract wordt 400 euro per verkocht kalf in rekening gebracht als voerkosten en de marge is gekoppeld aan de prijswijziging van de melk uit het MAGNET-model. De opbrengst van vleeskalveren op contract is vastgesteld op 650 euro per verkocht kalf. Omdat deze dieren op contractbasis worden gehouden, ontvangen deze bedrijven een netto contractbetaling waarbij onder andere deze onderdelen worden gesaldeerd en de kalverhouder uiteindelijk een vergoeding krijgt voor de arbeid en het ingezette kapitaal. 
Wageningen Economic Research Postbus 29703

2502 LS Den Haag

T 0703358330

Ecommunications.ssg@wur.nl

www.wur.nl/economic-research

Wageningen Economic Research RAPPORT 2020-065
De missie van Wageningen University \& Research is 'To explore the potential of nature to improve the quality of life'. Binnen Wageningen University \& Research bundelen Wageningen University en gespecialiseerde onderzoeksinstituten van Stichting Wageningen Research hun krachten om bij te dragen aan de oplossing van belangrijke vragen in het domein van gezonde voeding en leefomgeving. Met ongeveer 30 vestigingen, 6.500 medewerkers ( $5.500 \mathrm{fte}$ ) en 12.500 studenten behoort Wageningen University \& Research wereldwijd tot de aansprekende kennisinstellingen binnen haar domein. De integrale benadering van de vraagstukken en de samenwerking tussen verschillende disciplines vormen het hart van de unieke Wageningen aanpak.

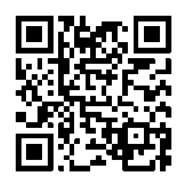





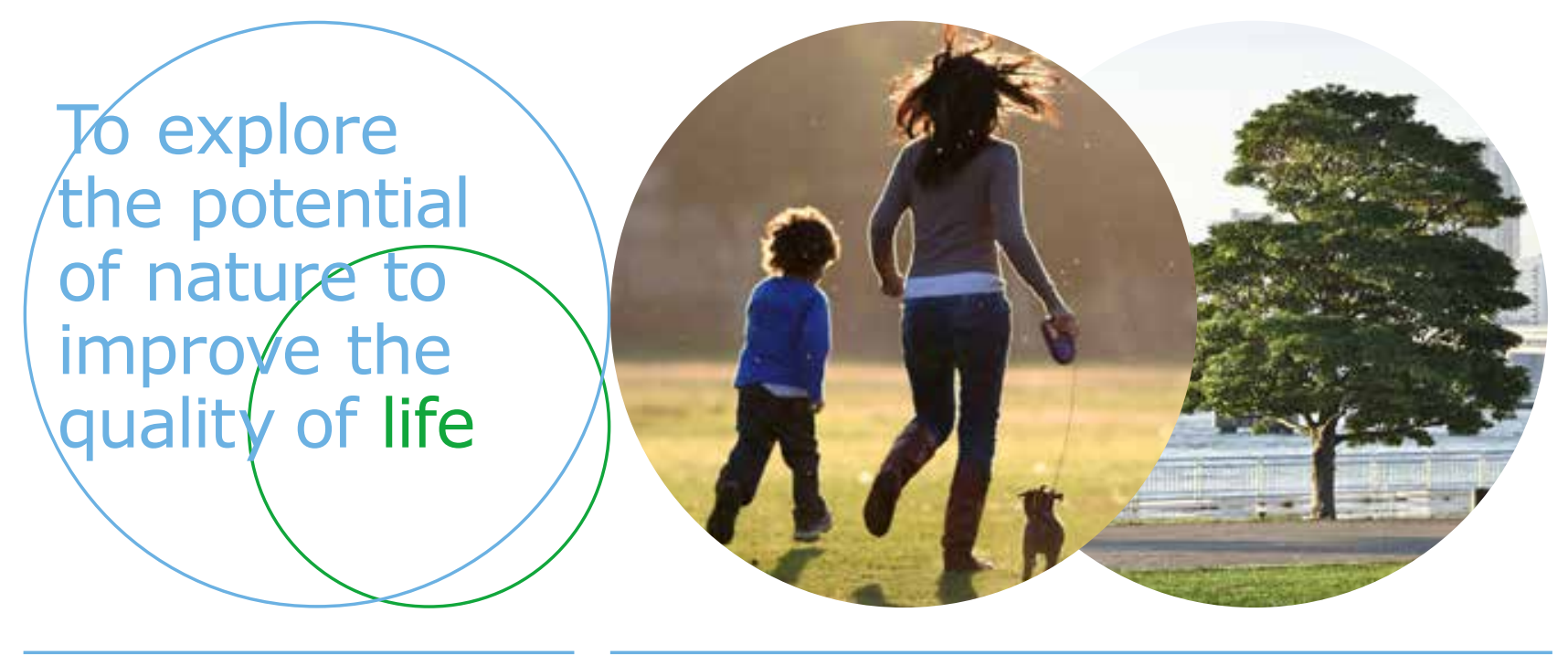

Wageningen Economic Research Postbus 29703

2502 LS Den Haag

T 0703358330

E communications.ssg@wur.nl www.wur.nl/economic-research

Rapport 2020-065

ISBN 978-94-6395-531-7
De missie van Wageningen University \& Research is 'To explore the potential of nature to improve the quality of life'. Binnen Wageningen University \& Research bundelen Wageningen University en gespecialiseerde onderzoeksinstituten van Stichting Wageningen Research hun krachten om bij te dragen aan de oplossing van belangrijke vragen in het domein van gezonde voeding en leefomgeving. Met ongeveer 30 vestigingen, 6.500 medewerkers ( $5.500 \mathrm{fte}$ ) en 12.500 studenten behoort Wageningen University \& Research wereldwijd tot de aansprekende kennisinstellingen binnen haar domein. De integrale benadering van de vraagstukken en de samenwerking tussen verschillende disciplines vormen het hart van de unieke Wageningen aanpak. 